Journal of the Society for the Study of Architecture in Canada Le Journal de la Société pour l'étude de l'architecture au Canada

\title{
Heritage Churches in the Niagara Region: An Essay on the Interpretation of Style
}

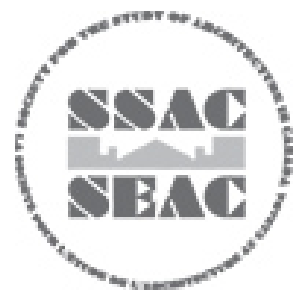

\section{Malcolm Thurlby}

Volume 43, numéro 2, 2018

URI : https://id.erudit.org/iderudit/1058039ar

DOI : https://doi.org/10.7202/1058039ar

Aller au sommaire du numéro

Éditeur(s)

SSAC-SEAC

ISSN

2563-8696 (numérique)

Découvrir la revue

Citer cet article

Thurlby, M. (2018). Heritage Churches in the Niagara Region: An Essay on the Interpretation of Style. Journal of the Society for the Study of Architecture in Canada / Le Journal de la Société pour l'étude de l'architecture au Canada, 43(2), 67-95. https://doi.org/10.7202/1058039ar 


\section{HERITAGE CHURCHES IN THE NIAGARA REGION: AN ESSAY ON THE INTERPRETATION OF STYLE ${ }^{1}$}

MALCOLM THURLBY, PH.D., F.S.A., teaches art and architectural history at York University, Toronto. His research concentrates on Romanesque and Gothic architecture and sculpture from the eleventh to the thirteenth century, and nineteenth-century Canadian architecture. He concurs with John Medley [1804-1892], Bishop of Fredericton from 1845 to 1892 , and champion of the Gothic revival in New Brunswick, that "some knowledge of Church Architecture ought, surely, to be part of every liberal education."

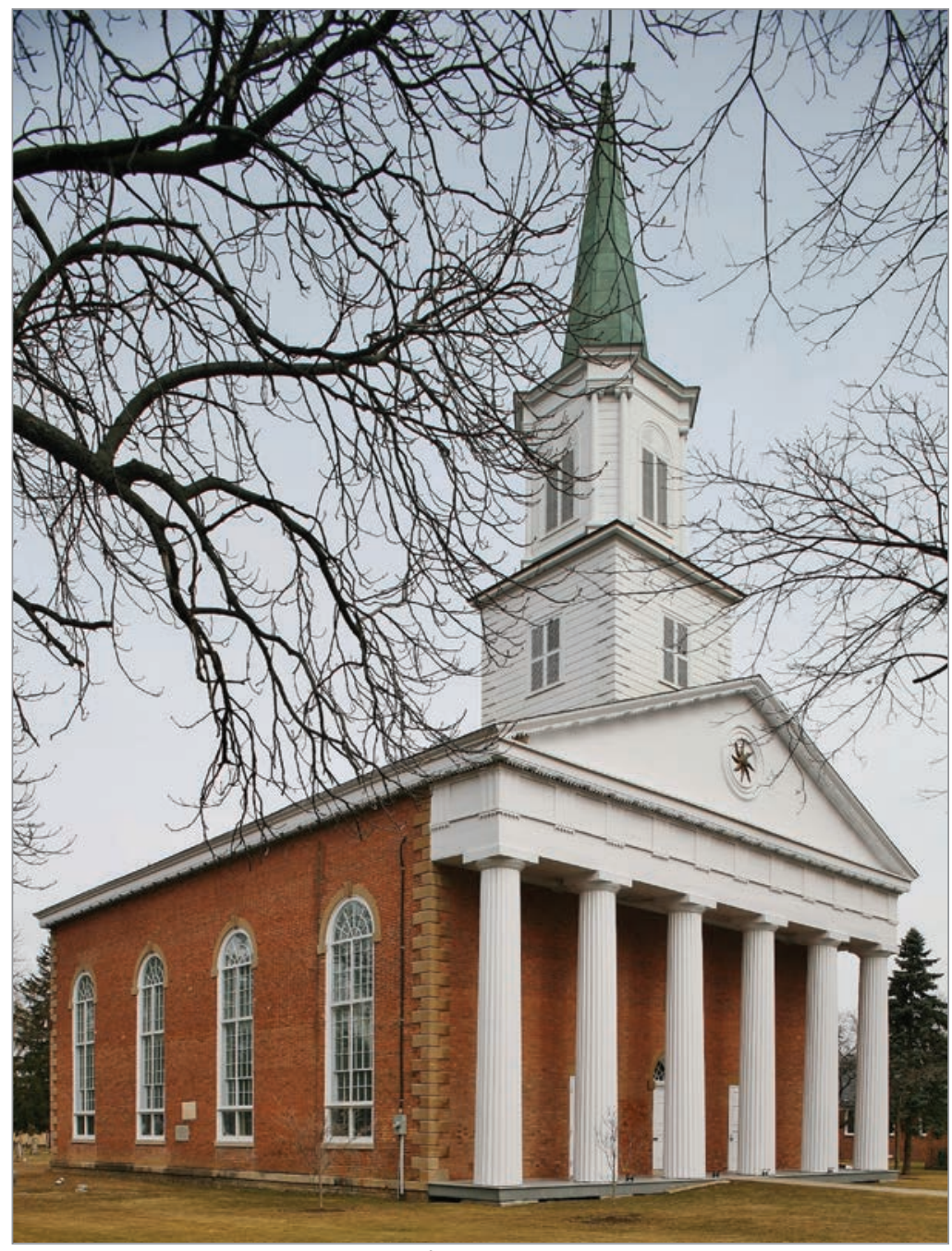

FIG. 1. NIAGARA-ON-THE-LAKE, ST. ANDREW'S PRESBYTERIAN CHURCH, 1831, EXTERIOR FROM SE. | MALCOLM THURLBY.

\author{
MALCOLM ThURLBY
}

$T_{\text {sion }}^{\mathrm{h}}$

his paper is an expanded version of a public lecture delivered in St. Andrew's Presbyterian Church, Niagara-on-the-Lake, Ontario, on May 25, 2017, as part of the Annual Meeting of the Society for the Study of Architecture in Canada. It examines some of the key heritage churches in the eastern part of the Regional Municipality of Niagara from St. Catharines in the north, Niagaraon-the-Lake in the northeast through Niagara Falls to Fort Erie in the southeast, and the towns of Thorold and Welland to the south of St. Catharines, along with some rural churches. Particular attention is paid to the style and use of the buildings in regard to the aims of the patron(s) and architect(s)/builder(s) in association with specific historical links and major trends in contemporary church design. The approach in essentially chronological and explores why the buildings look the way they do. It opens with St. Andrew's Presbyterian Church, Niagara-on-theLake, a well-known neoclassical building but not previously investigated for its specific Scottish connections. The subsequent account of individual churches adopts the same principles in a quest to understand expressions of ethnicity in churches of different denominations. The group of churches was chosen because of its proximity to the conference venue, but the principles are applicable to the study of Canadian church architecture as a whole.

\section{ST. ANDREW'S PRESBYTERIAN CHURCH, NIAGARA-ON-THE-LAKE²}

The present St. Andrew's Presbyterian Church was constructed in 1831 under 


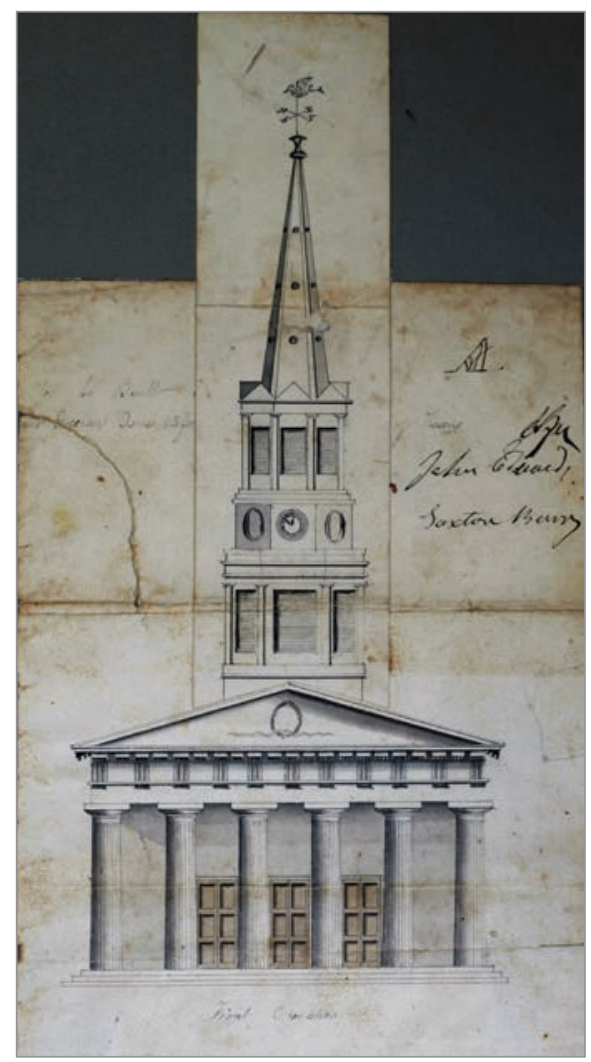

FIG. 2. JAMES COOPER, DRAWING FOR THE FAÇADE OF ST. ANDREW'S, NIAGARA-ON-THE-LAKE, 1831. | MALCOLM THURLBY.

the direction of the pastor, Robert McGill [1798-1856], who had arrived from Glasgow in October 1829. ${ }^{3}$ His conscientious and energetic leadership is seen in his role in the foundation of the Synod of the Presbyterian Church of Canada in connection with the Church of Scotland in June 1831, and as founder of the monthly Canadian Christian Examiner and Presbyterian Review, in March 1837. ${ }^{4}$ The Articles of Agreement pertaining to St. Andrew's, made on March 17, 1831, specified a one-storey brick church seventythree feet by fifty-five feet and thirty feet in height in the Grecian Doric style. ${ }^{5}$ The design of the church was entrusted to one James Cooper, about whom little is known. He was a member of the congregation of St. Andrew's and in 1831 had been awarded First Premium for his

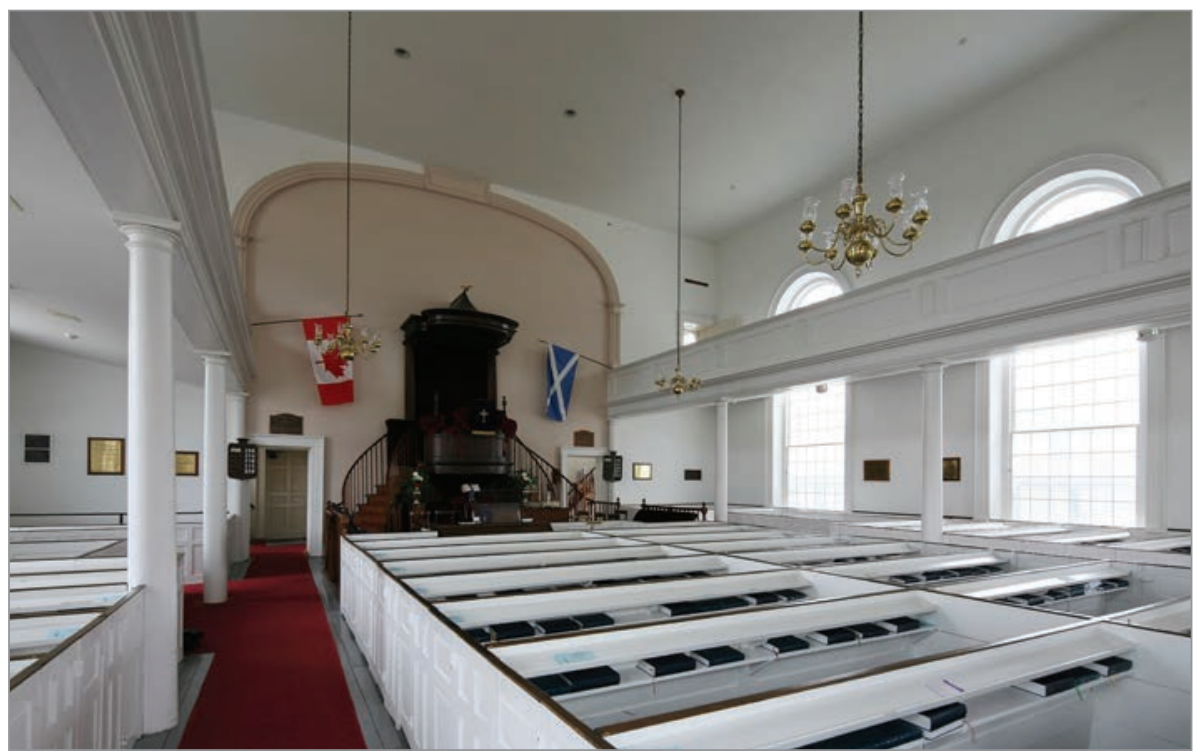

FIG. 3. NIAGARA-ON-THE-LAKE, ST. ANDREW'S PRESBYTERIAN CHURCH, INTERIOR TO PULPIT. | MALCOLM THURLBY.

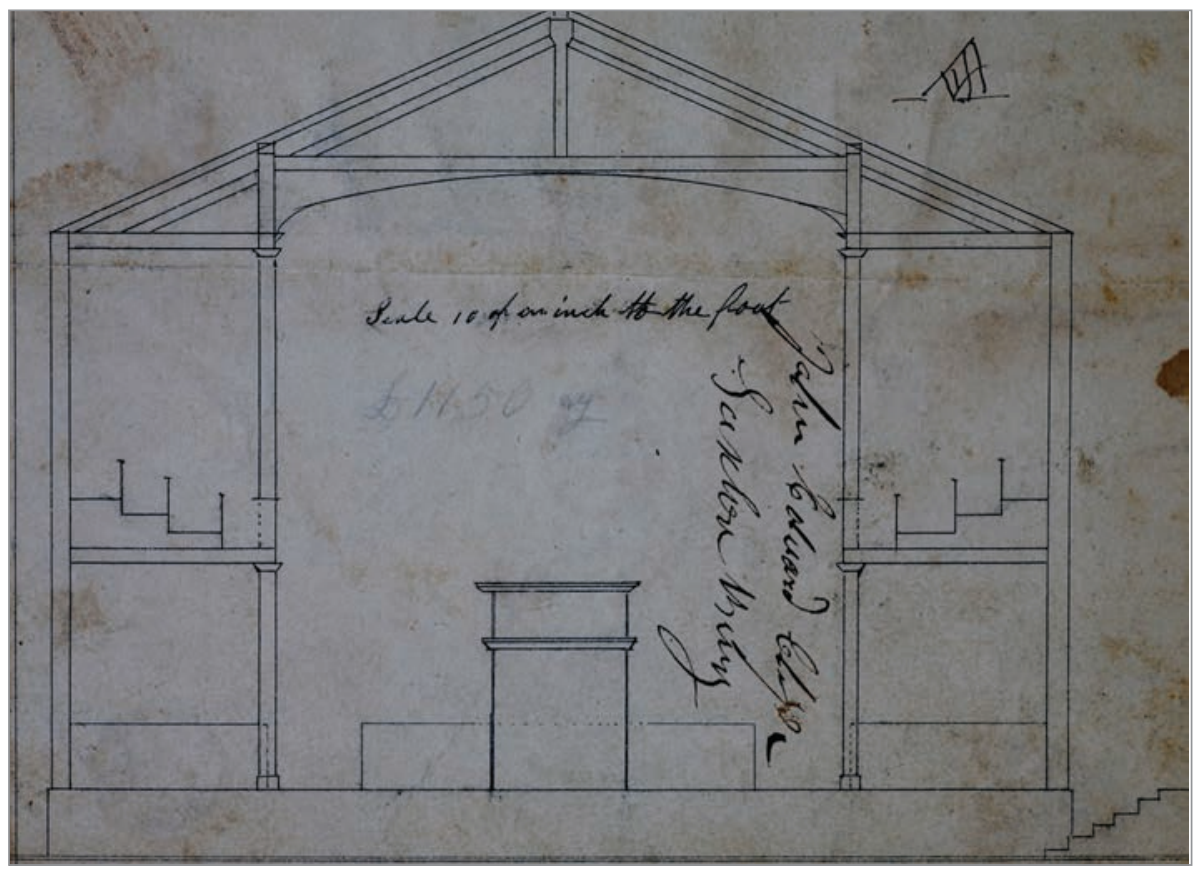

FIG. 4. NIAGARA-ON-THE-LAKE, ST. ANDREW'S PRESBYTERIAN CHURCH, CROSS SECTION OF SANCTUARY.| MALCOLM THURLBY.

design for the Market House in York (now Toronto), for which there were four other competitors. ${ }^{6}$ The contractors were John Edward Clyde and Saxton Burr, carpenters and joiners of Niagara (on-the-Lake). The 1831 church is considerably more ambitious than its predecessor in terms of the larger scale, grander tower and spire, and portico. Fortunately, Cooper's drawings have survived and are preserved in the church archives. 


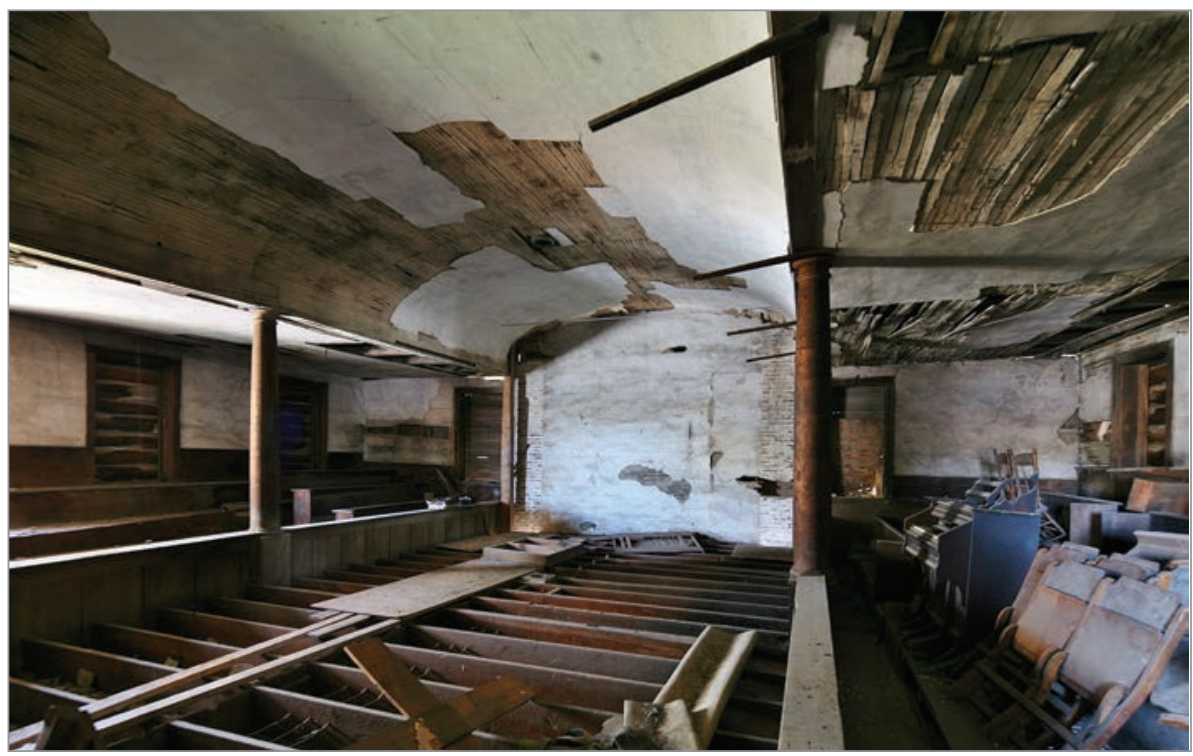

FIG. 5. BEAVERDAMS METHODIST CHAPEL, 1834, INTERIOR FROM SW GALLERY. | MALCOLM THURLBY.

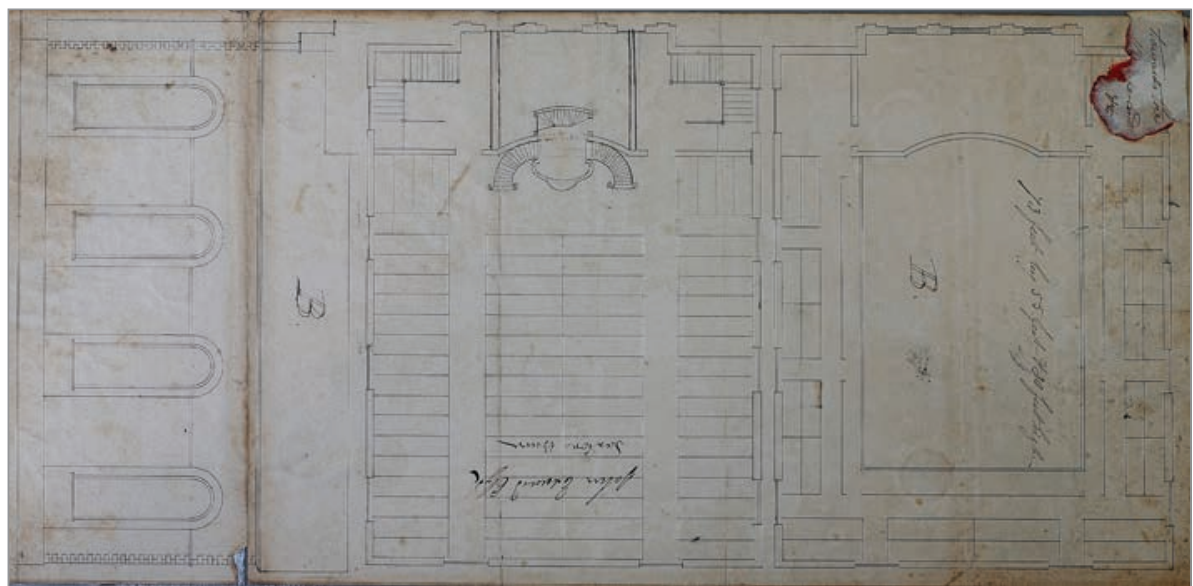

FIG. 6. NIAGARA-ON-THE-LAKE, ST. ANDREW'S PRESBYTERIAN CHURCH, PLAN AND SIDE ELEVATION.. | MALCOLM THURLBY.

\section{Description}

Like many churches in North America, the starting point for the design is James Gibbs's [1682-1754] church of St. Martinin-the-Fields, London (1721-1726), and other Gibbs's churches published in his Book of Architecture, of which Sir John Summerson said: "it was probably the most widely used architectural book of the century, not only throughout Britain but in the American colonies and the West Indies" (figs. 1-2).7 The rectangular plan incorporates the sanctuary, vestibule, portico, and tower with spire. St. Andrew's is smaller than its English counterparts and yet is remarkably ambitious in the inclusion of the hexastyle Greek Doric portico. The primary building material is red brick with stone used for the quoins, plinth, windowsills, and heads with emphasized keystones and springers, as also used on the three doorways. The façade and tower are of wood in imitation of stone with the careful use of tongue-and-groove planks

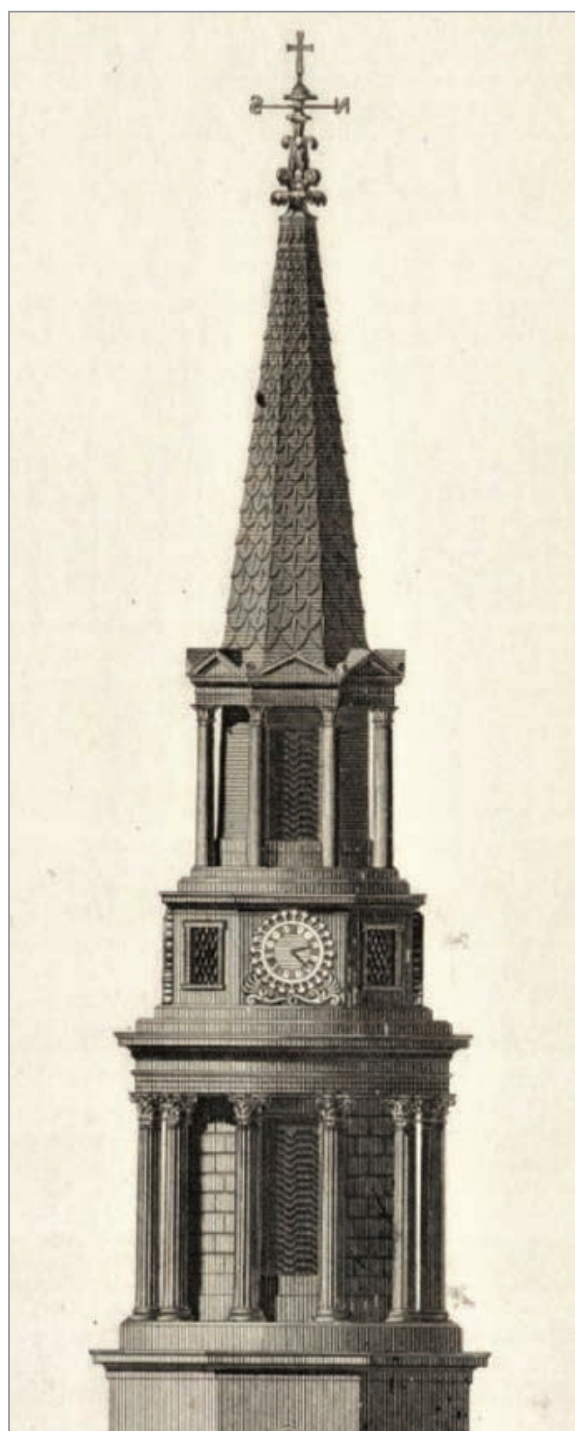

FIG. 7. NICHOLSON, THE NEW PRACTICAL BUILDER, AND WORKMAN'S COMPANION, CHURCH IN THE GRECIAN STYLE, DETAIL OF TOWER AND SPIRE, N.P. | MALCOLM THURLBY.

in the entablature, pediment, and the tower. There is careful attention to correct Greek Doric detailing, although fillets rather than arrises are used between the flutes of the shafts, probably because a wooden arris would have been more susceptible to damage than the sturdier fillet. Aside from that slip from archaeological grace, the desire to reproduce a marble or limestone original was so great that fictive masonry drums are created with horizontal incisions on the shafts so as to imitate 


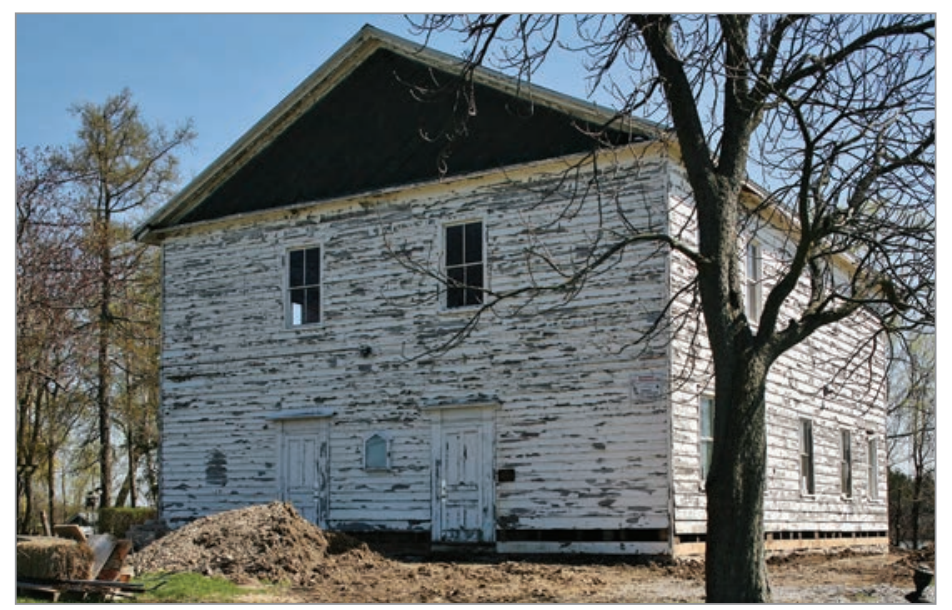

FIG. 8. BEAVERDAMS METHODIST CHAPEL, EXTERIOR. | MALCOLM THURLBY.

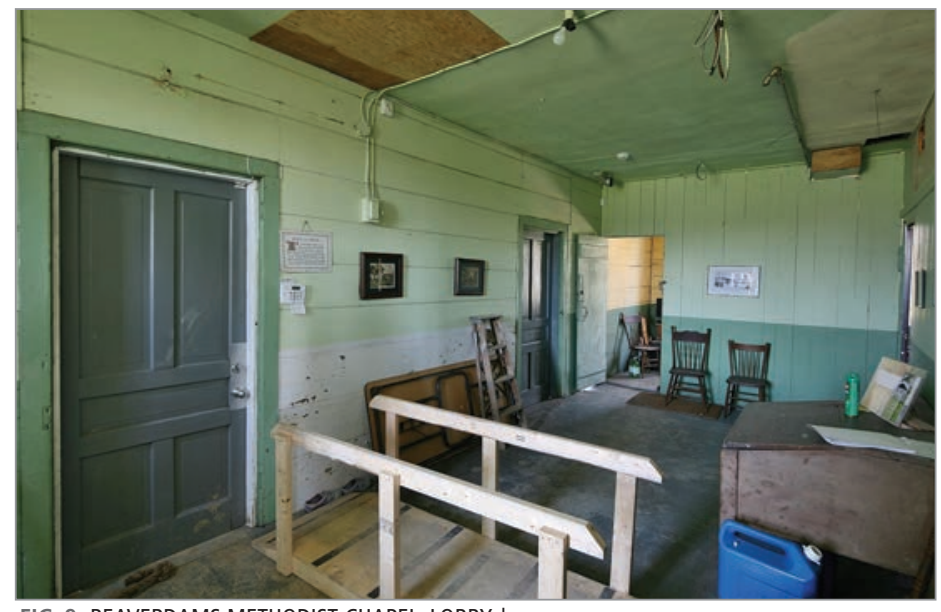

FIG. 9. BEAVERDAMS METHODIST CHAPEL, LOBBY. | MALCOLM THURLBY.

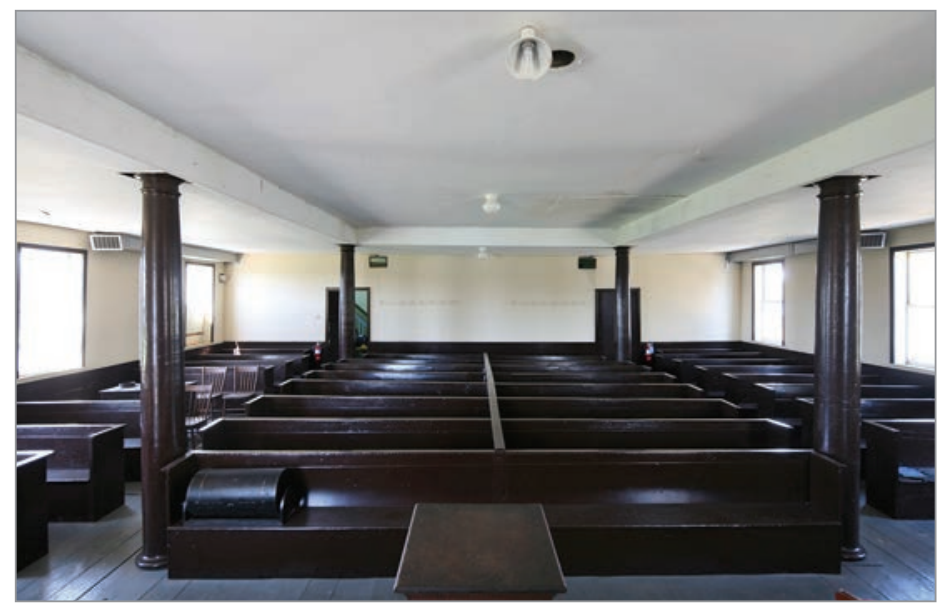

FIG. 10. BEAVERDAMS METHODIST CHAPEL, SANCTUARY, INTERIOR FROM PULPIT. | MALCOLM THURLBY.

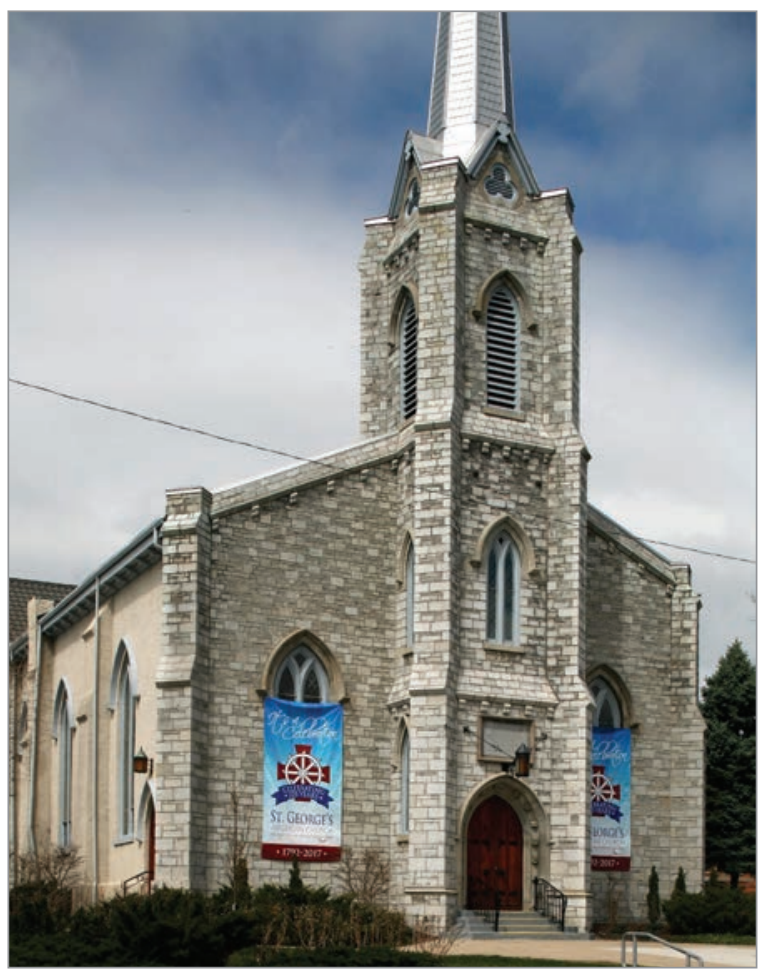

FIG. 11. ST. CATHARINES, ST. GEORGE'S ANGLICAN CHURCH, 1844, EXTERIOR. | MALCOLM THURLBY.

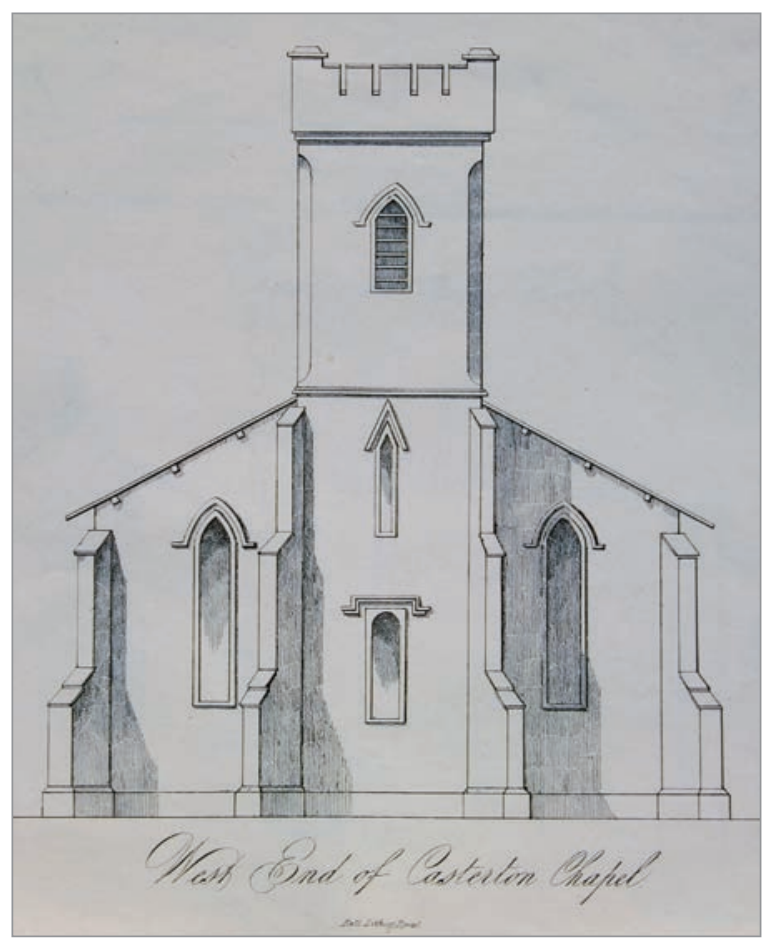

FIG. 12. CARTERTON (WESTMORLAND), CHAPEL, FAÇADE, FROM WILSON, HELPS TO THE BUILDING OF CHURCHES, PL. 2. | MALCOLM THURLBY. 


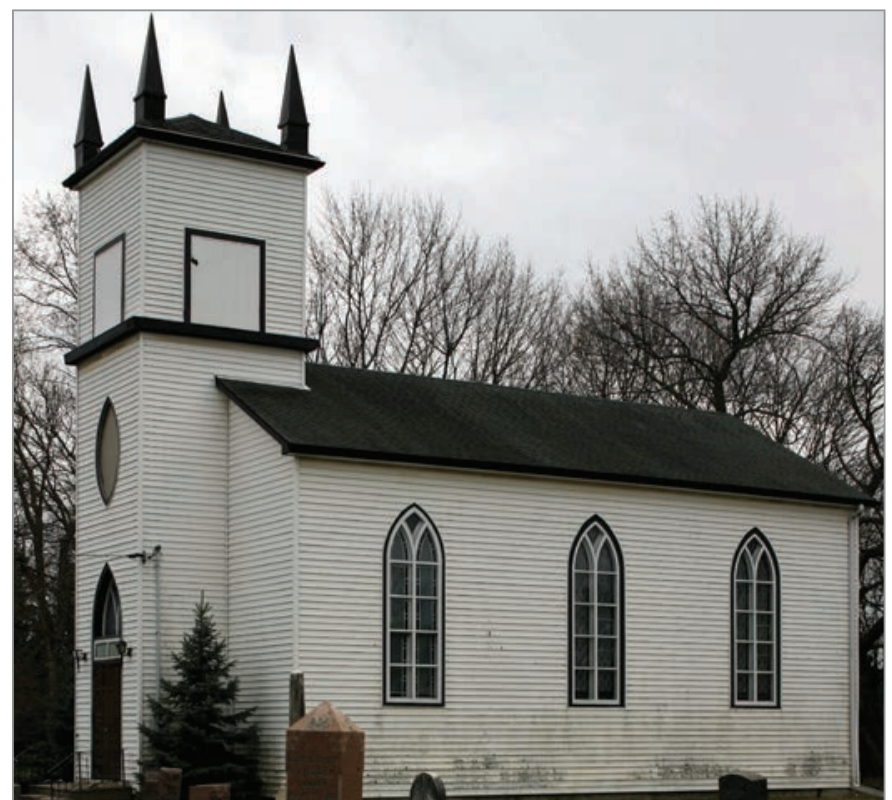

FIG. 13. PORT ROBINSON, ST. PAUL'S ANGLICAN CHURCH (1844), EXTERIOR FROM SW. | MALCOLM THURLBY.

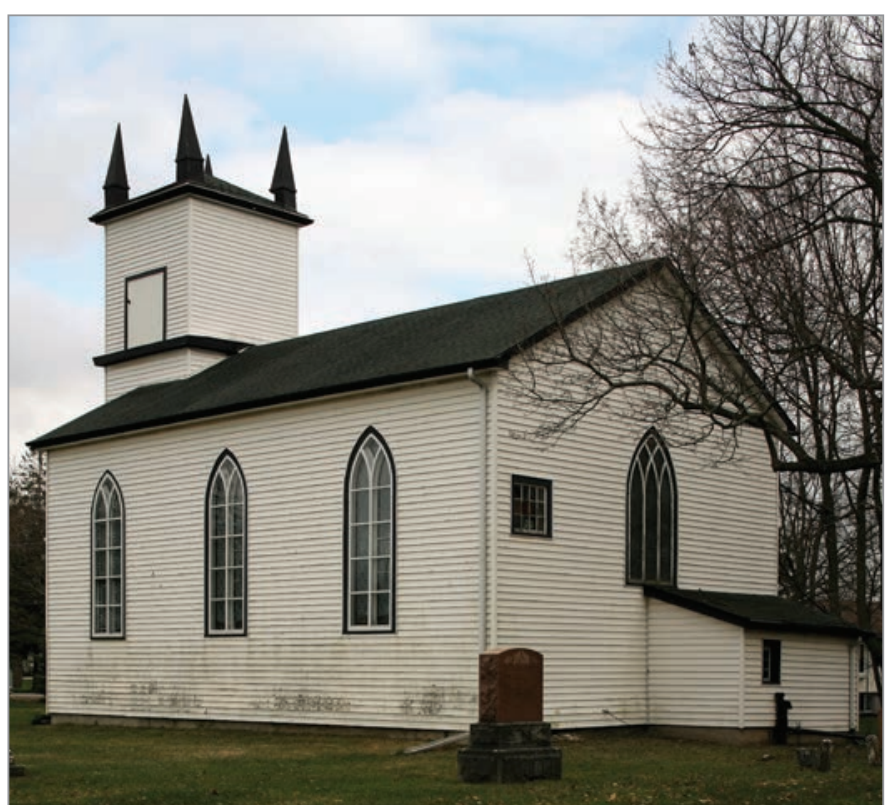

FIG. 14. PORT ROBINSON, ST. GEORGE'S ANGLICAN CHURCH, EXTERIOR FROM SE. | MALCOLM THURLBY. joints. Such a mimetic approach was commonplace at the time, except where one could call on a local supply of stone as in Kingston, Ontario. Even in the much larger and architecturally ambitious city of Hamilton, located seventy-seven kilometres to the west of Niagara-on-the-Lake, Christ's Anglican Church designed in 1835 by the English-trained architect Robert Wetherell [d. 1845] was a frame building. ${ }^{8}$ St. Andrew's remains in a remarkably good state of preservation and retains its 1831 form except for the present tower and spire by the Irish-trained, Toronto-based, Kivas Tully [1820-1905], which date from 1856 after the originals had blown down in a hurricane on April 18, 1855. ${ }^{9}$

The interior arrangement of St. Andrew's is unusual (fig. 3). For members of the congregation passing through the portico, the vestibule is entered through one of the lateral doorways. Across the vestibule there are the doors to the sanctuary, while turning left or right there are stairs to the gallery. Entering the sanctuary, one does not face the pulpit and communion table.
Instead, the arrangement is reversed so that the pulpit is located between the doorways from the vestibule. Sneaking in late for a service might have been embarrassing! There are two aisles that return across the end of the sanctuary, and the gallery, which is carried on Tuscan Doric columns without bases, occupies the side and end walls. Cooper's cross section of the church shows a depressed barrel vault carried on gallery columns, which would have been constructed in lath and plaster like Beaverdams Methodist Church (1834), located twenty-five kilometres southwest of Niagara-on-the-Lake (Beaverdams is now part of Thorold) (figs. 4-5). Whether the depressed barrel vault was constructed is not known given the damage caused by the fall of the tower in 1855 and the subsequent rebuilding of the ceiling. It is likely that the giant segmental arch which now frames the pulpit was introduced by Tully in his 1856 restoration of the church. The arrangement of the pews is different from Cooper's plan, and, again, this may be Tully's work (fig. 6).
Other modifications to Cooper's drawings were made before the start of construction. On the plan, two walls are introduced to subdivide the vestibule into three, which are clearly not part of Cooper's design because they cut into the side doorways (fig. 6). As Marion MacRae and Anthony Adamson observed, this division would have come about at the will of Reverend McGill so as to provide the minister with a space separated from the lateral entrances for the congregation. ${ }^{10}$ From the minister's vestibule stairs rose the pulpit from which the minister could make a rather theatrical entrance. The central doorway in the façade is also changed to a larger, arched form to differentiate it from the side entrances (figs. 1-2). The planned projection of the entrance bays is abandoned in favour of a flat wall and, inside the sanctuary, the curved section of the wall behind the pulpit is straightened (figs. 3-6). The pulpit, executed in 1840 by the local master carpenter John Davidson, is more elaborate than originally planned (figs. 3-4). 


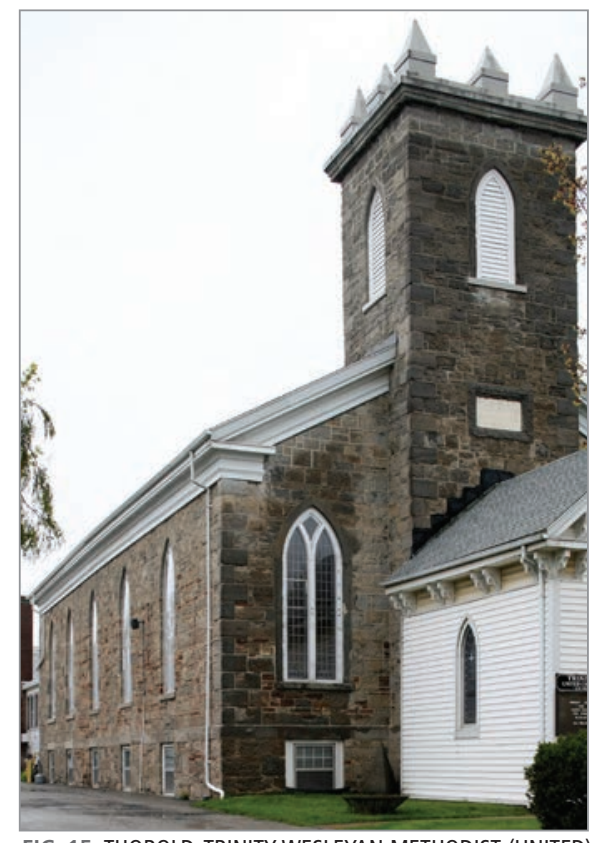

FIG. 15. THOROLD, TRINITY WESLEYAN METHODIST (UNITED) CHURCH, 1845, EXTERIOR FROM NW (SE). | MALCOLM THURLBY.

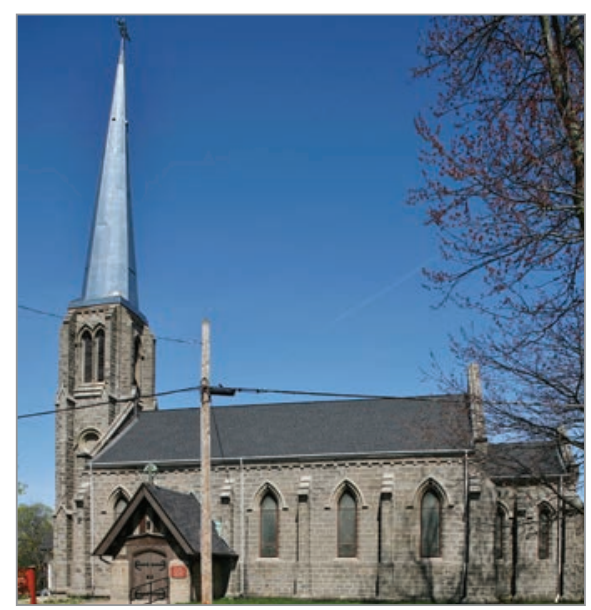

FIG. 17. THOROLD, ST. JOHN THE EVANGELIST CHURCH, 1852, EXTERIOR S. | MALCOLM THURLBY.

\section{Historiography of St. Andrew's}

MacRae and Adamson have indicated that an important source the design of St. Andrew's was the "Plan for a Church" in Asher Benjamin's Rudiments of Architecture published in 1820.11 Benjamin translates the Gibbsian pattern into a North American scale and

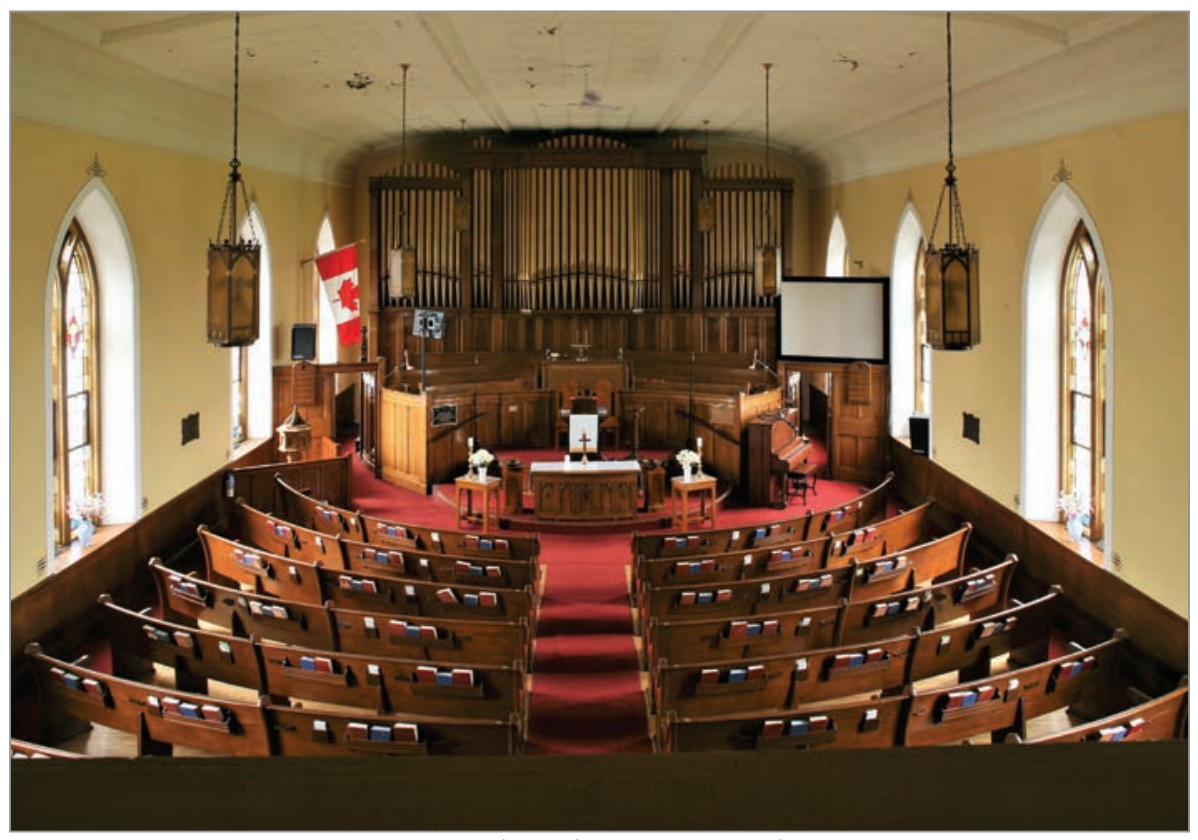

FIG. 16. THOROLD, TRINITY WESLEYAN METHODIST (UNITED) CHURCH, INTERIOR. | MALCOLM THURLBY.

includes a rectangular nave with a vestibule and stairs to the gallery behind a hexastyle portico. Specifically, the four bays of round-headed windows set in enclosing arches, which are closely followed by Cooper in his original design (fig. 6). This was modified in execution with the abandonment of the enclosing arch (figs. 1 and 6). The continuous order was also modified to include a stone arch for the window with a keystone and projecting stops like Benjamin's detail for the inside of the window. Cooper follows Benjamin's hexastyle portico but with a significant change from Roman to Greek Doric and with uniform intercolumniation rather than Benjamin's more practical spacing in relation to the three doorways to the church. The interior arrangement of St. Andrew's is quite distinct from Benjamin's plan, although the arrangement of the pulpit with curved stairs from left and right followed a model of Benjamin's Country Builder's Assistant. ${ }^{12}$ MacRae and Adamson also refer to the pattern books of Peter Nicholson, of which The New Practical Builder, and Workman's Companion includes a description and illustrations of a Church in a Grecian Style. ${ }^{13}$

While the hexastyle portico is presaged by Benjamin's publication, it is significant that Cooper's design is quite different in its precise reference to the Greek Doric order. We have to explain how and why this came about. Is it a matter of adopting Greek from the American practice or is there a different iconographic agenda?

\section{Analysis}

The design of St. Andrew's is remarkably ambitious in the inclusion of the hexastyle portico as in Gibbs's St. Martin-in-theFields, modified from the Corinthian to the Doric order after the Hephaisteion (Temple of Theseus), as in James Stuart and Nicolas Revett's Antiquities of Athens. ${ }^{14}$ This is unique in British North America until the 1840s. The earliest reference to Gibbs for the model of a church design is in St. Paul's Anglican Church, Halifax, Nova Scotia 


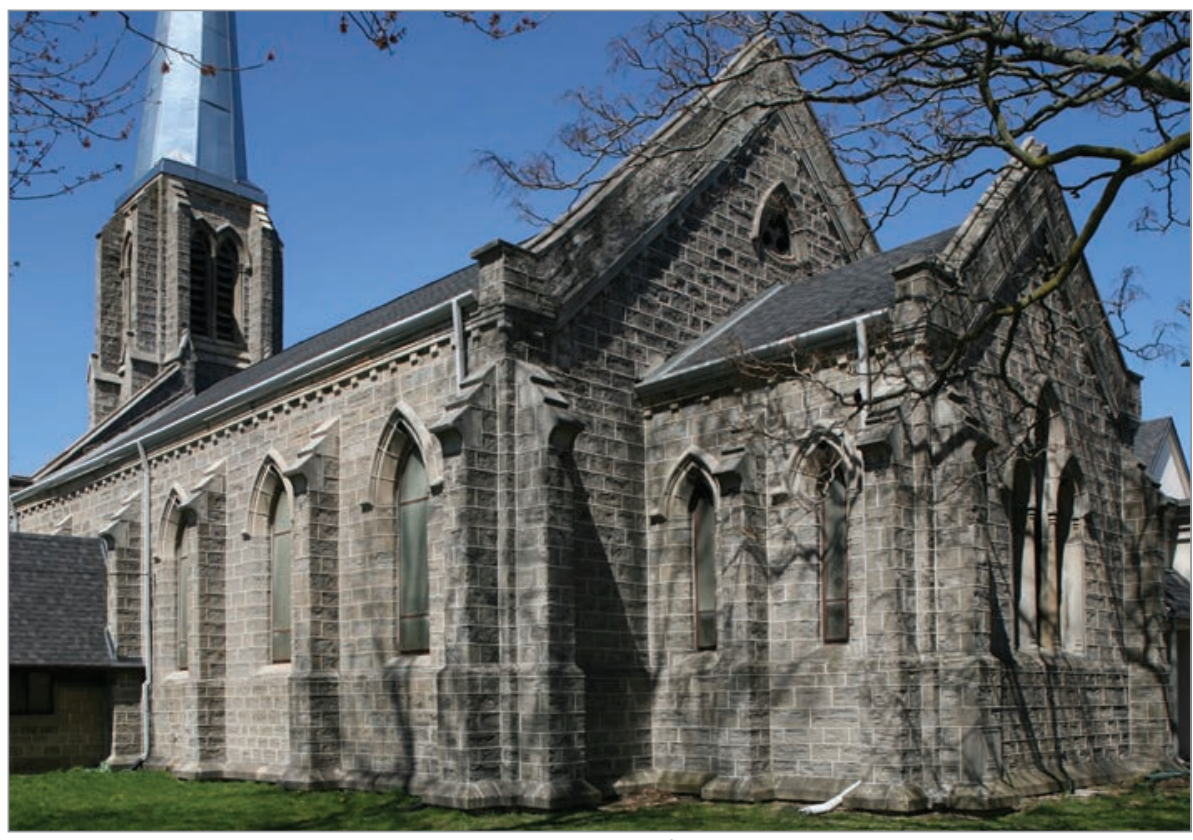

FIG. 18. THOROLD, ST. JOHN THE EVANGELIST CHURCH, EXTERIOR SE. | MALCOLM THURLBY.

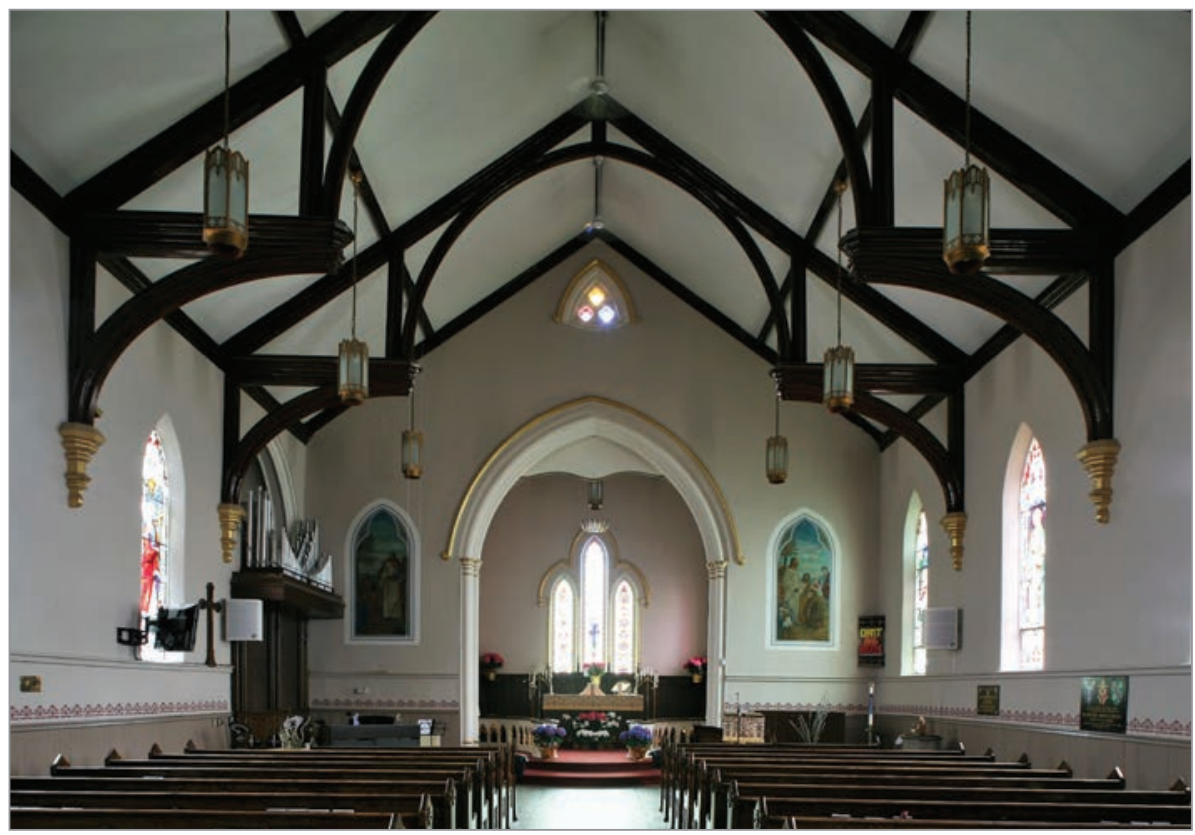

FIG. 20. THOROLD, ST. JOHN THE EVANGELIST CHURCH, INTERIOR TO E. | MALCOLM THURLBY.

(1749), which is based on St. Peter's Vere Street (Marylebone Chapel, 1722), London, and does not have a portico. ${ }^{15}$ Similarly, Holy Trinity Anglican Cathedral, Quebec
City (1800-1804), is modelled closely on St. Martin-in-the-Fields but omits the portico. ${ }^{16}$ Of churches in Toronto in the 1830s and 1840s none uses a hexastyle temple

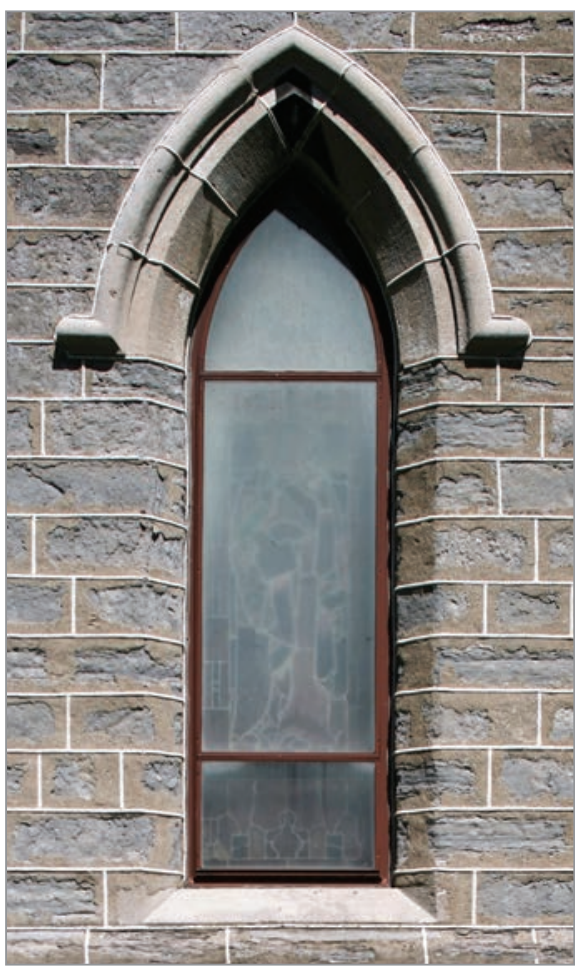

FIG. 19. THOROLD, ST. JOHN THE EVANGELIST CHURCH, EXTERIOR S, WINDOW DETAIL. | MALCOLM THURLBY.

façade. The cornerstone of St. Andrew's Presbyterian Church in Toronto was laid in June 1830 and the first service was held on June $19,1834 .{ }^{17}$ The church adopted Wren-Gibbs classicizing design principles with a three-bay façade including a slightly projecting central bay commenced in 1830, and a tower and spire added above the central bay of the façade by John G. Howard [1803-1890] in 1839.18 The second St. James's Anglican Church in Toronto (1833) by Thomas Rogers [c. 1780-1853], followed a Gibbsian rectangular plan with staircases flanking the partially projecting tower on King Street, which was planned for an elaborate tower that was not completed. ${ }^{19}$ Following the fire in 1839 , St. James's was rebuilt on the same scale and with only minor changes to the overall appearance. ${ }^{20}$ When the church reopened in December 1839, it had cathedral status 


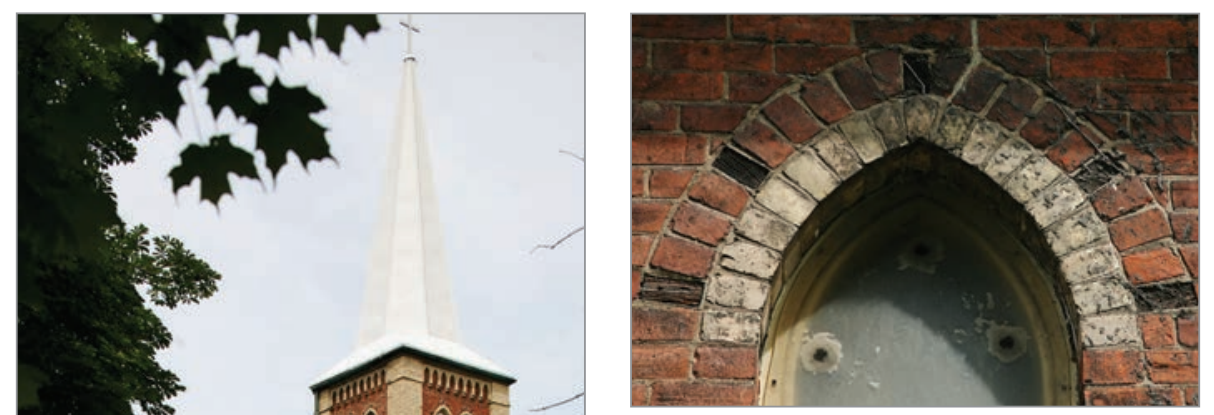

FIG. 23. MCNAB, CHRIST CHURCH ANGLICAN, WINDOW DETAIL. | MALCOLM THURLBY.

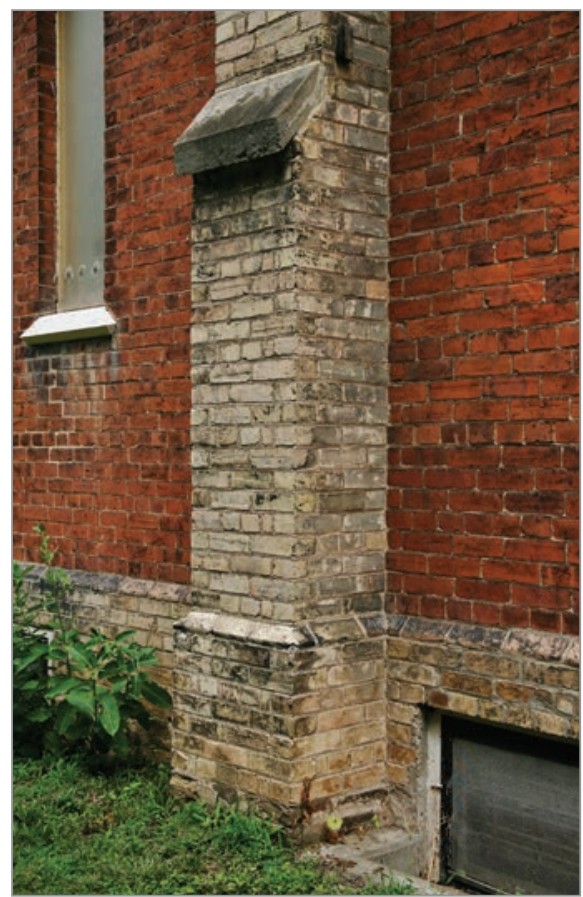

FIG. 24. MCNAB, CHRIST CHURCH ANGLICAN, BUTTRESS DETAIL. | MALCOLM THURLBY.

church with a portico in Richmond Street Methodist by the Yorkshire-trained builder Richard Woodsworth, yet it was tetrastyle Roman Doric. 22

FIG. 22. MCNAB, CHRIST CHURCH ANGLICAN, EXTERIOR NE. | MALCOLM THURLBY.

and yet not the architectural grandeur of St. Andrew's, Niagara-on-the-Lake. As for the Zion Congregational Church, Toronto (1839), the façade had two Doric columns in antis and a short tower above. ${ }^{21}$ It was not until 1844 that Toronto could boast a was anticipated with much architectural activity, including the city hall which was commenced in 1839 by the Irish-trained architect George Browne [1811-1885], who created a suitably scaled-down version of James Gandon's [1743-1823] Custom House in Dublin, commenced in 1781. At the very same time, Thomas Roger's 1825 Anglican Church of St. George (cathedral from 1862) was provided with a tetrastyle portico and an octagonal belfry and cupola above the southern (liturgically western) bay of the nave to the design of William Coverdale [1801-1865], between 1839 and 1842. ${ }^{23}$ The use of local Kingston limestone might be deemed more prestigious than the wood of the portico and tower of St. Andrew's, Niagara-on-the-Lake, but it did not compete with the hexastyle portico nor the relative height of the tower. ${ }^{24}$ The Presbyterian church in Kingston by Archibald Fraser [d. c. 1853] was built in 1820 according to Gibbsian-design principles with an octagonal tower terminating in a dome surmounted by a thin lantern, and a three-bay façade articulated with pilasters, but without the portico of St. Andrew's. ${ }^{25}$

In Montreal, the American Presbyterian Church by Moses Marshall (1825) made reference to two churches from the third edition of Benjamin's American Builder's Companion, but lacked a portico. ${ }^{26}$ Greek Doric columns in antis were used for the façade of Shearith Israel Synagogue, Montreal, begun 1835 by John Wells [1789-1864]. ${ }^{27}$ We have to wait until 1844 for the first hexastyle portico for a religious building in Montreal; the Second Congregational Church by Wells of $1844 . .^{28}$ This was followed in 1845 by a tetrastyle Roman Doric portico to East End Methodist Church by William Footner [1799-1872], ${ }^{29}$ and the hexastyle Greek Doric portico of the Unitarian Church, Beaverhall Place (1845), also by Footner, 


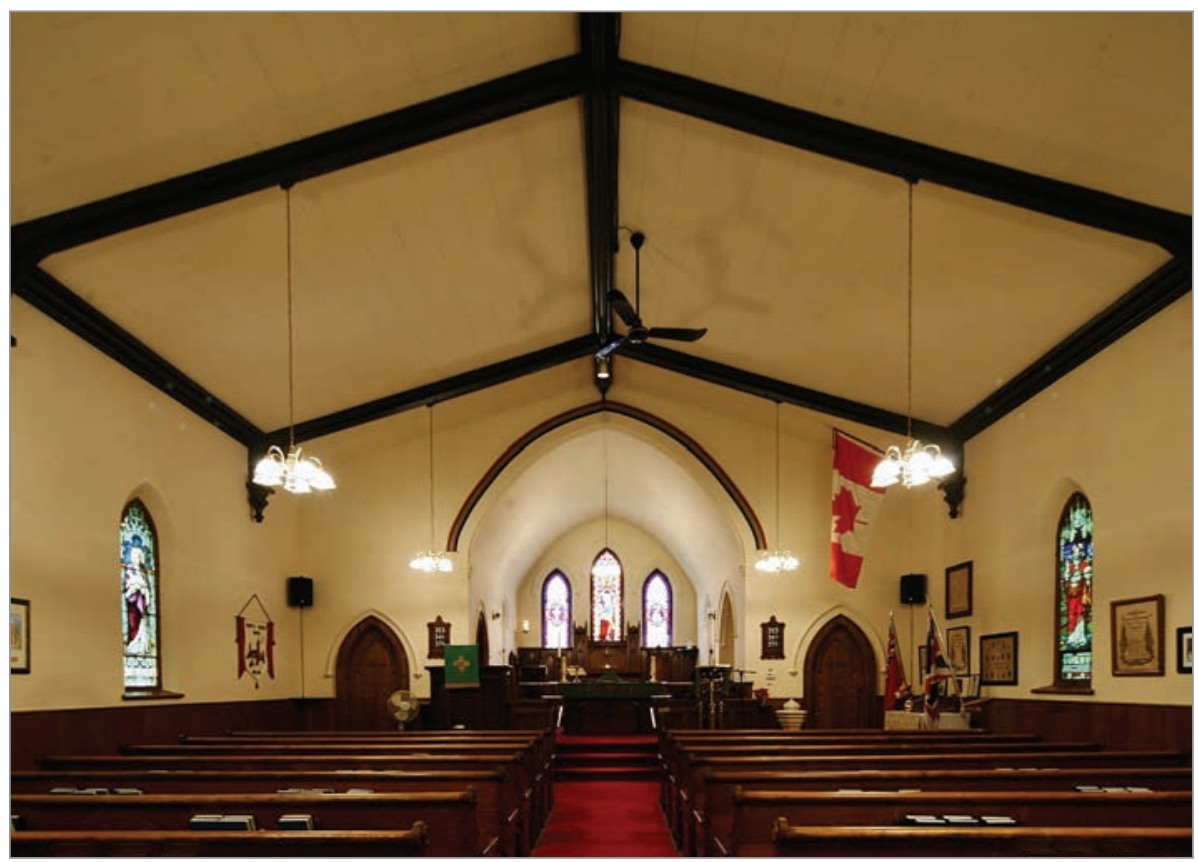

FIG. 25. MCNAB, CHRIST CHURCH ANGLICAN, INTERIOR TO E. | MALCOLM THURLBY.

which was based on the Propylaea on the Acropolis in Athens. ${ }^{30}$ Even across the border from Niagara-on-the-Lake in New York State, Western Presbyterian Church, Palmyra (1832), just has a four-columned temple façade.

Whether or not Cooper had access to Stuart and Revett's Antiquities of Athens is a moot point. The book was expensive and David Watkin has noted that of the five hundred subscribers to the first volume, only four were architects and three were builders. ${ }^{31}$ In its absence, Nicholson's Principles of Architecture provides detailed nomenclature of the Greek Doric order and gives instructions "To draw the elevation of the Grecian Doric Order." ${ }^{22}$ He recommends several exemplars, including the Temple of Theseus for which he provides a description and two plates. ${ }^{33}$ Nicholson's The Students' Instructor in Drawing and Working the Five Orders of Architecture does what the title suggests and provides step-by-step guidance, including practical information such as how "to glue up the shaft of a column." ${ }^{34}$ Nicholson's design for a Church in the Grecian Style published in The New Practical Builder, and Workman's Companion is important for our purposes. ${ }^{35}$ His tetrastyle Corinthian portico is of no consequence for St. Andrew's, but his tower and spire are an important source for Cooper. Cooper takes Nicholson's fivestage exemplar and substitutes Doric for Corinthian in his simplified design, but retains the clock in the third stage and the small pediments above the octagonal fourth stage (figs. 2 and 7). Here the use of rectangular openings on all eight sides is modified with reference to Benjamin's design for a Meeting House in his American Builder's Companion. ${ }^{36}$ Cooper then adapts the same principle to the second stage of his tower. Benjamin is also informative with instructions on how "To draw the elevation of a Grecian Doric Order." 37 Similarly, in The Architect, or Practical House Carpenter, he provides an account of the Greek Doric Order with specific reference to the Temple of Theseus, of which he illustrates details. ${ }^{38}$ In his 1826 Rudiments of Architecture, Joseph Gwilt lists the Temple of Theseus as one of the principal examples of Grecian Doric, of which he illustrates details in plate III. ${ }^{39}$ Mention should also be made of John Haviland [1792-1852], the English-born architect who trained in London with James Elmes [1782-1862]. He moved to Philadelphia in 1816 where he became a leading neoclassical architect. He designed the First Presbyterian Church, Philadelphia (18201822), with a hexastyle Ionic portico which was repeated in his St. Andrew's Episcopal Church, Philadelphia (18221823). Most importantly for our purposes, he published the three-volume Builder's Assistant, Containing the Five Orders of Architecture, for the Use of Builders, Carpenters, Masons, Plasterers, Cabinet Makers, and Carvers..., in which he illustrates the New Presbyterian Church. ${ }^{40} \mathrm{He}$ also details a Doric entablature and capital from the Temple of Minerva, Athens. ${ }^{41}$

St. Andrew's, Niagara-on-the-Lake, is the earliest example of Greek revival architecture in British North America and as such may be seen as vying with the grandest churches of the Anglican establishment, like St. Pancras, London (1819-1822), by Henry William Inwood [1794-1843] and his father William Inwood [c. 1771-1843]. Near-contemporary churches in London have Greek Doric hexastyle porticoes as at St. George's, Camberwell (1822-1824), and St. John, Waterloo Road, Lambeth (1823-1824), both by Francis Bedford [1784-1858]. In Scotland, St. Mary's, Belleview Crescent, Edinburgh (18241826), by Thomas Brown [1781-1850], has a Corinthian hexastyle temple façade. Broughton Place Church, Edinburgh (18201821), by Archibald Elliott [1761-1823], has a Greek Doric tetrastyle portico. Further north in Elgin (Moray), St. Giles Church of Scotland (1827), by Archibald Simpson 


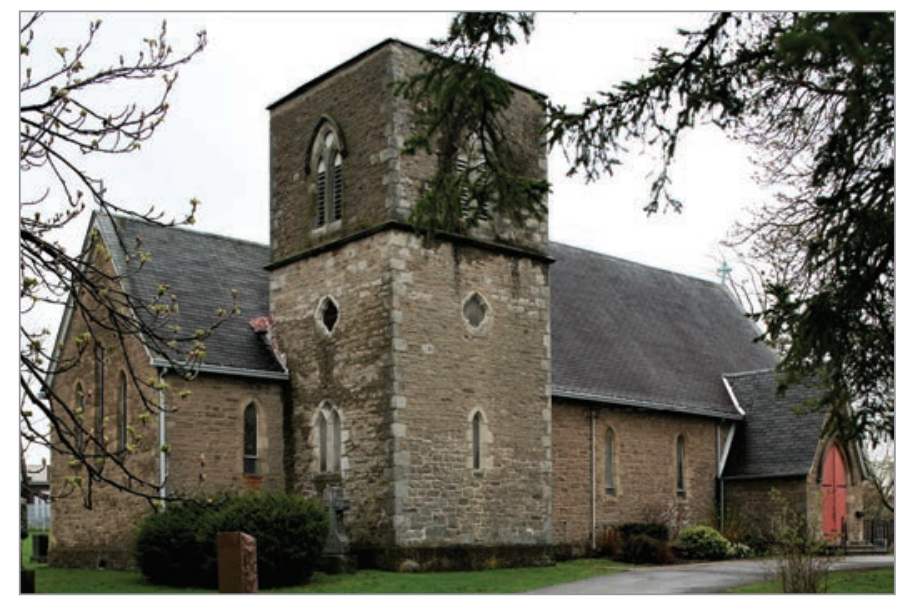

FIG. 26. NIAGARA FALLS, ALL SAINTS ANGLICAN (1856-1857), EXTERIOR FROM NE. | MALCOLM THURLBY.

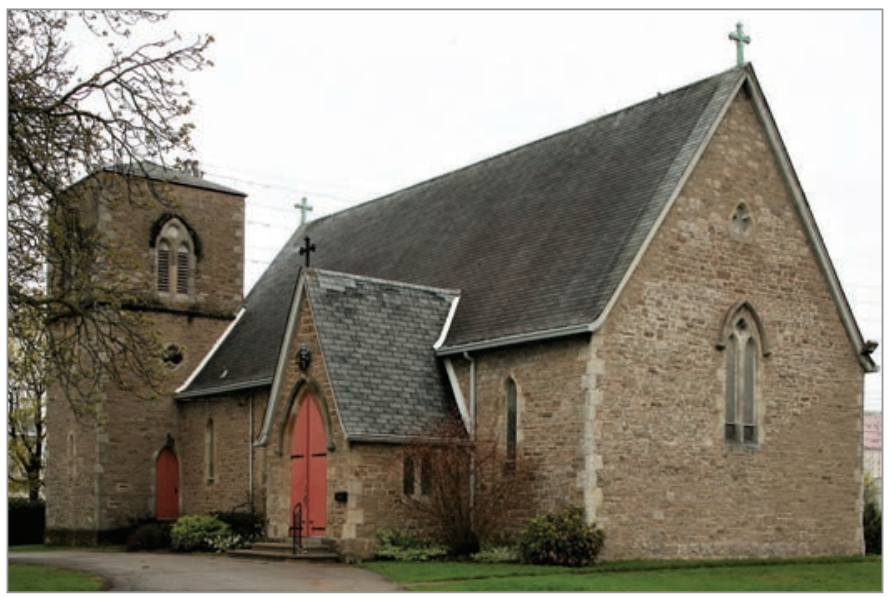

FIG. 27. NIAGARA FALLS, ALL SAINTS ANGLICAN, EXTERIOR FROM NW. | MALCOLM THURLBY.
[1790-1847], boasts a Greek Doric hexastyle portico surmounted by a tower modelled on the Choragic Monument of Lysicrates in Athens.

Architectural patronage in the new world frequently aimed at the creation of memories of the homeland and, with that in mind, Reverend McGill would have been keen to establish an appropriately Scottish image for his new church. There is nothing in his native Ayr (Ayrshire), but he may have recalled the grandeur of the Gibbsian-inspired St. Andrew's parish church, Glasgow (1739-1756), by Allan Dreghorn [1706-1765] and Mungo Naismith [1730-1770], with its hexastyle Corinthian portico. The Corinthian order would hardly have been appropriate for McGill's new church: The Oxford Dictionary of the Christian Church describes Presbyterian worship as "simple, orderly and dignified" for which the Greek Doric order provides suitable expression. ${ }^{42}$

The Greek Doric order was most appropriate for a Scottish edifice in the new world given the promotion of Edinburgh as the "Athens of the North," 43 an epithet credited to Hugh William Williams [1773-1829], an Edinburgh landscape painter nicknamed
"Grecian" Williams, whose travels in Italy and Greece between 1816 and 1818 resulted in the publication of Travels in Italy, Greece and the Ionian Islands, in 1820.44 In 1822 and 1826, he exhibited watercolours from his travels, and another illustrated publication, Select Views in Greece, appeared in 1829. It may be significant that there is an illustration of the Temple of Theseus, Athens, in this book. ${ }^{45}$

An article titled "On the Proposed National Monument at Edinburgh," published in 1819 in Blackwood's Edinburgh Magazine, brought the matter of architectural style and national taste to the attention of the general public. ${ }^{46}$ The author stated that this was "a subject in which we think not only the citizens of the metropolis, but all the inhabitants of Scotland should feel interested." ${ }^{47} \mathrm{He}$ further said: "We cannot avoid saying a few words on the design which should be followed in this national edifice, and the influence which the adoption of a perfect model is fitted to have on the national taste, ${ }^{\text {"48 }}$ observing that "[t]here is no fact more certain than that a due appreciation of the grand or the beautiful in architectural design, is not inherent in any individual or any people; and that towards the formation of a correct public taste, the existence of fine models is absolutely essential." ${ }^{49} \mathrm{He}$ argued that the

\footnotetext{
National Monument is an edifice of a very singular kind, and such to require a style of architecture peculiar to itself. The Grecian Doric, as it is exhibited in the Parthenon, appears singularly well adapted to this purpose. Its form and character is associated in every cultivated mind with the recollections of classical history, and it recalls the brilliant conceptions of national glory as they were received during the ardent and enthusiastic period of youth. ${ }^{50}$
}

The matter of taste is once again emphasized: "The effect of such a building and the influence it would have on the public taste, would be increased to an infinite degree, by the interest of the purpose to which it is destined." The monument was designed by Charles Robert Cockerell [1788-1863] and William Henry Playfair [1790-1857] in 1824 as a copy of the Parthenon, but just twelve columns and the architrave were completed. The status of Edinburgh is once more promoted in John Britton's Modern Athens: Displayed in a Series of Views of Edinburgh in the Nineteenth Century. ${ }^{51}$ It illustrates a number of buildings with Greek Doric porticoes, including the Royal Institution 


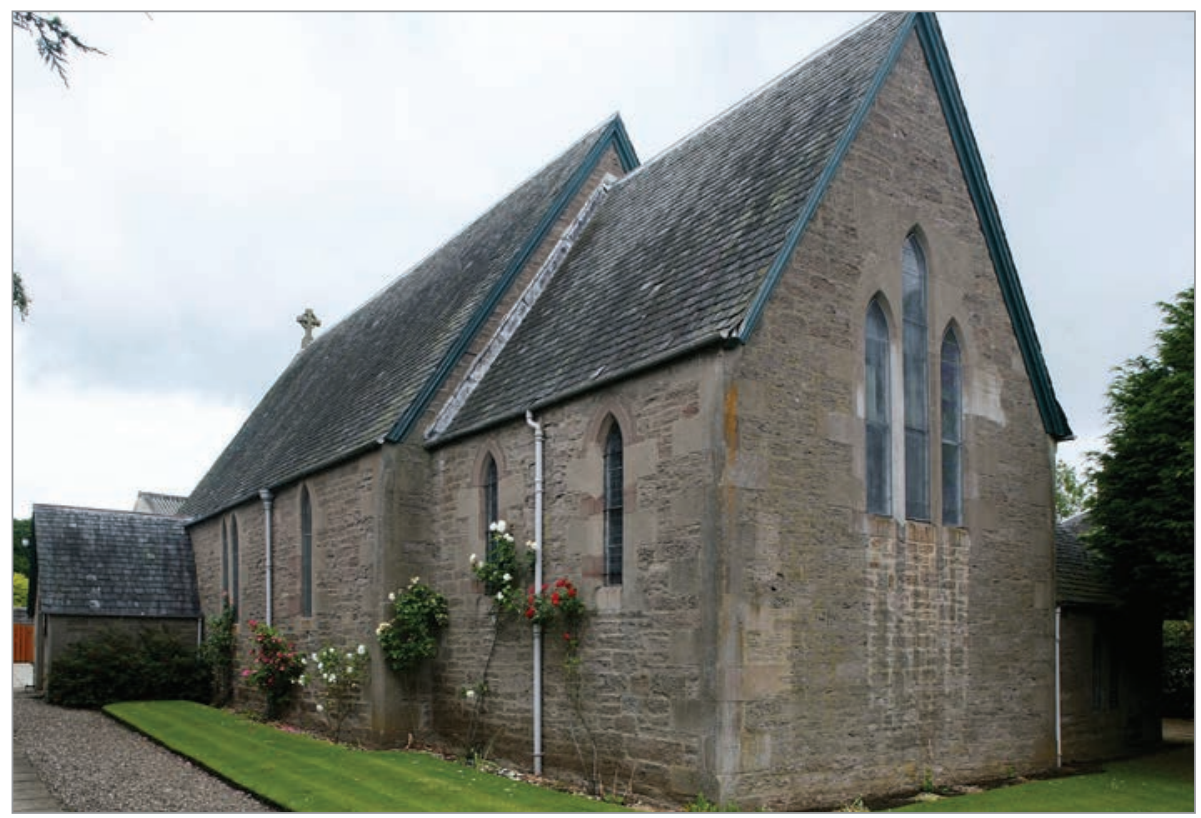

FIG, 28. COUPAR ANGUS (PERTHSHIRE), ST. ANNE'S EPISCOPAL CHURCH, 1848, EXTERIOR FROM SE. | MALCOLM THURLBY.

(Royal Scottish Academy) with its octostyle Greek Doric portico by William Playfair (1822-1826), which may have been significant for McGill with his keen interest in education. ${ }^{52}$

Cooper's original tower was destroyed in the storm of 1855 and replaced in 1856 with the present tower by Tully. ${ }^{53}$ Tully's tower is simpler and omits the clock stage, but he follows Cooper's reference to Benjamin in the use of paired lonic columns on the angled sides of the octagon (fig. 1)..$^{54}$

Rivalries in building are frequent in the history of architecture, not least in growing communities in British North America. In Niagara-on-the-Lake, St. Mark's Anglican Church was constructed between 1804 and 1810 , and rebuilt after the 1812 war with the interior finished in 1828. The rubble walls were rendered in imitation of ashlar, there were round-headed windows with emphasized keystones, a polygonal apse, and partially projecting western tower with an open octagonal belfry and short spire. The temple façade and elaborate tower and spire of St. Andrew's imparted monumentality lacking at St. Mark's. St. Vincent de Paul Roman Catholic Church was commenced in 1834. On a similar scale to St. Andrew's, St. Vincent de Paul is a frame building with a partially projecting tower surmounted by a simple octagonal spire. Perhaps most significantly, the pointed arch takes over from the semi-circular at St. Andrew's. For the windows, the tracery in the arch is formed by the curved continuation of the vertical muntins in the tradition of Batty Langley's [1696-1751] central bay (of a tripartite window) of a "Gothick Window for a Pavillion." ${ }^{55}$ And, following the principles of Langley in Gothicizing classical motifs, the pilasters and Ionic capitals of the apse arch are made Gothic with the introduction of pointed elements. ${ }^{56}$

\section{Summary of St. Andrew's}

St. Andrew's Presbyterian Church, Niagara-on-the-Lake, is one of the most important buildings in British North America, indeed, in the history of architecture in Canada. The design adopts principles established and promoted in Gibbs's Book of Architecture, Peter Nicholson's pattern books, and American publications like those of Asher Benjamin. What is so remarkable is the use of the hexastyle Greek Doric portico well over a decade before such a monumental façade was first used on a church in Montreal. Moreover, the choice of Greek Doric proclaimed the presence of the Presbyterian Church and the national style of Scotland in Upper Canada.

We now turn to an examination of some other churches in the region, initially those that reflect Gibbs's tradition, and then those inspired by the revival of medieval styles.

\section{Beaverdams Methodist Chapel}

While less ambitious than St. Andrew's, Niagara-on-the-Lake, the Methodist Chapel at Beaverdams shares a number of features with the Presbyterian Church (figs. 5 and 8-10). ${ }^{57}$ Built in 1832, Beaverdams Chapel does not boast the temple-form façade, tower, and spire of St. Andrew's. Clapboard siding is preferred over brick masonry with stone dressings. Beaverdams works with the same planning principles. The rectangular plan has two doorways on one of the short sides that access a shallow lobby from which there are doorways to the sanctuary and stairs at either end leading to the gallery (figs. 8-9). The ground floor of the sanctuary is here illustrated from the pulpit platform; it seems that the wooden columns and benches are original (fig. 10). The present ceiling was introduced in 1876 and consequently the original elevation is only appreciated when the gallery is inspected (fig. 5). Here some of the original benches remain as well as the original lath-andplaster segmental barrel vault in the tradition of Gibbs's St. Martin-in the-Fields. The chapel is currently being lovingly restored by the Friends of Beaverdams Church. ${ }^{58}$ 


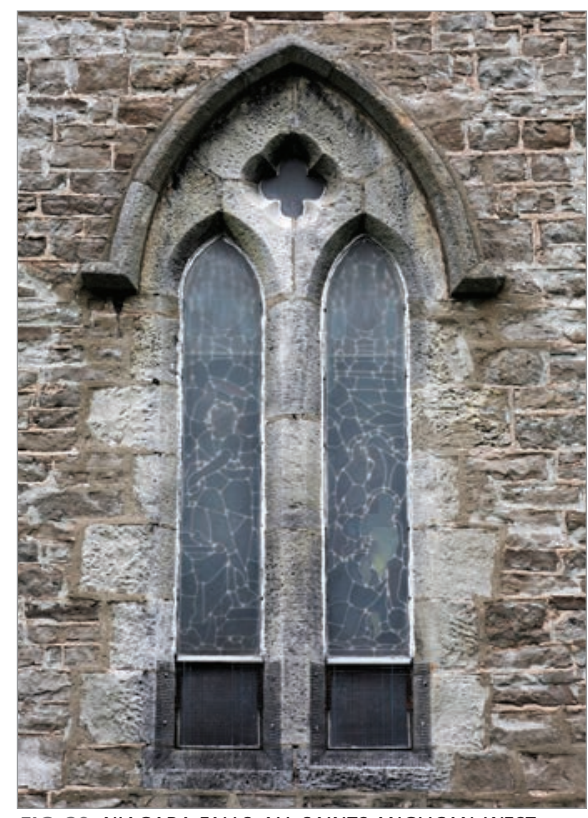

FIG. 29. NIAGARA FALLS, ALL SAINTS ANGLICAN, WEST WINDOW. | MALCOLM THURLBY.

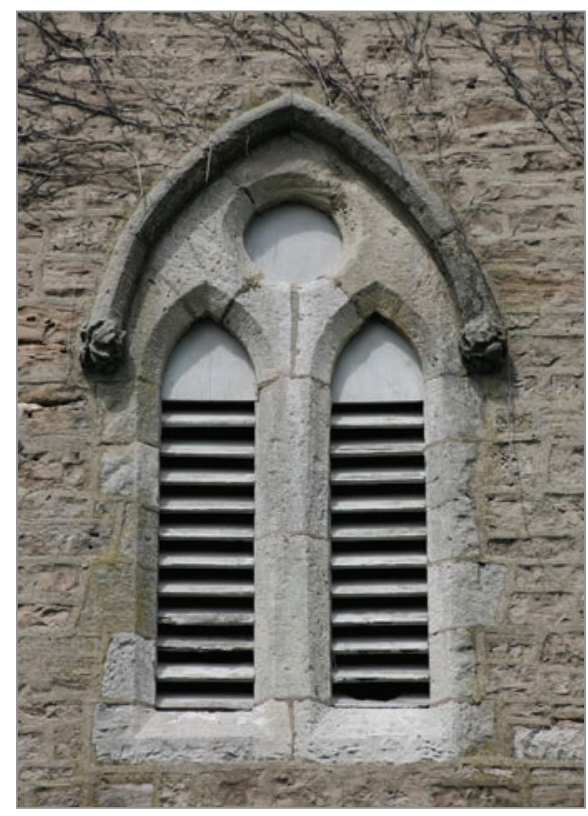

FIG. 30. NIAGARA FALLS, ALL SAINTS ANGLICAN, E BELFRY OPENING. | MALCOLM THURLBY.

\section{St. Catharines Presbyterian Church}

In St. Catharines, the 1834 Presbyterian Church, which was replaced by the present edifice in 1877, also followed

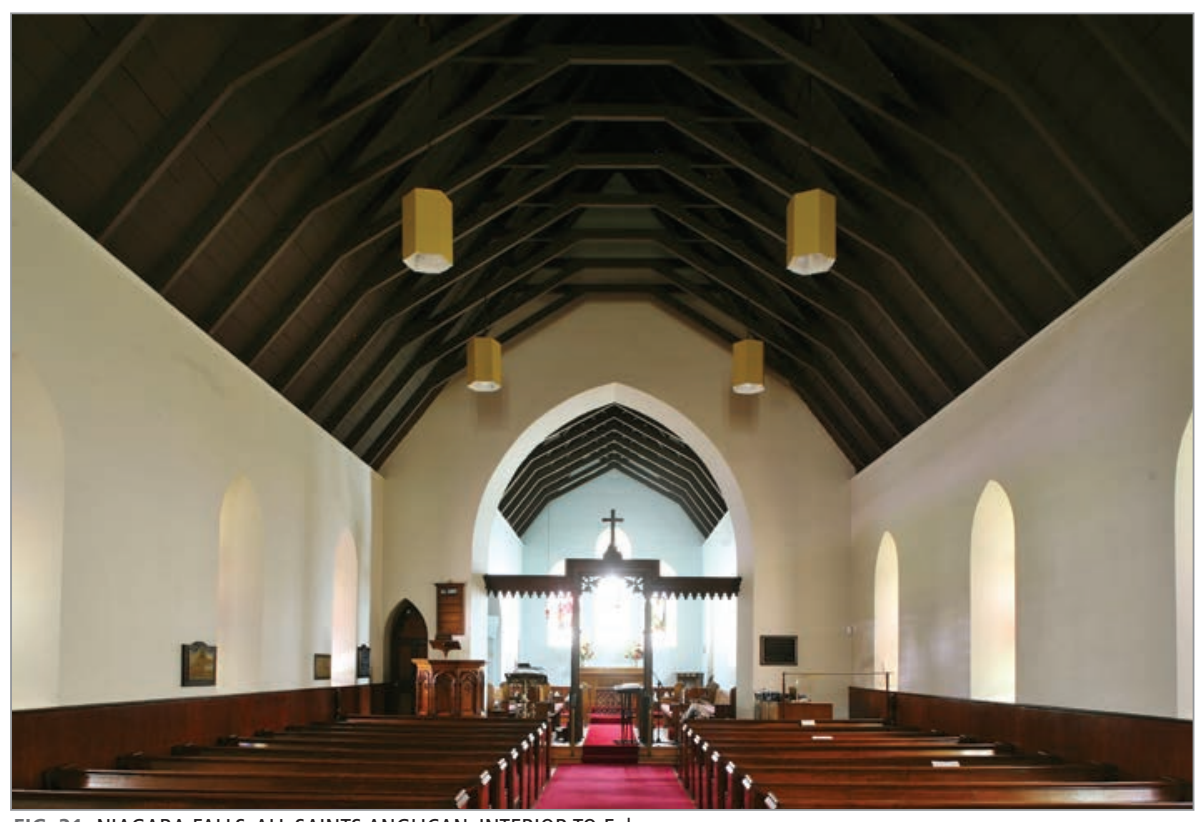

FIG. 31. NIAGARA FALLS, ALL SAINTS ANGLICAN, INTERIOR TO E. | MALCOLM THURLBY.

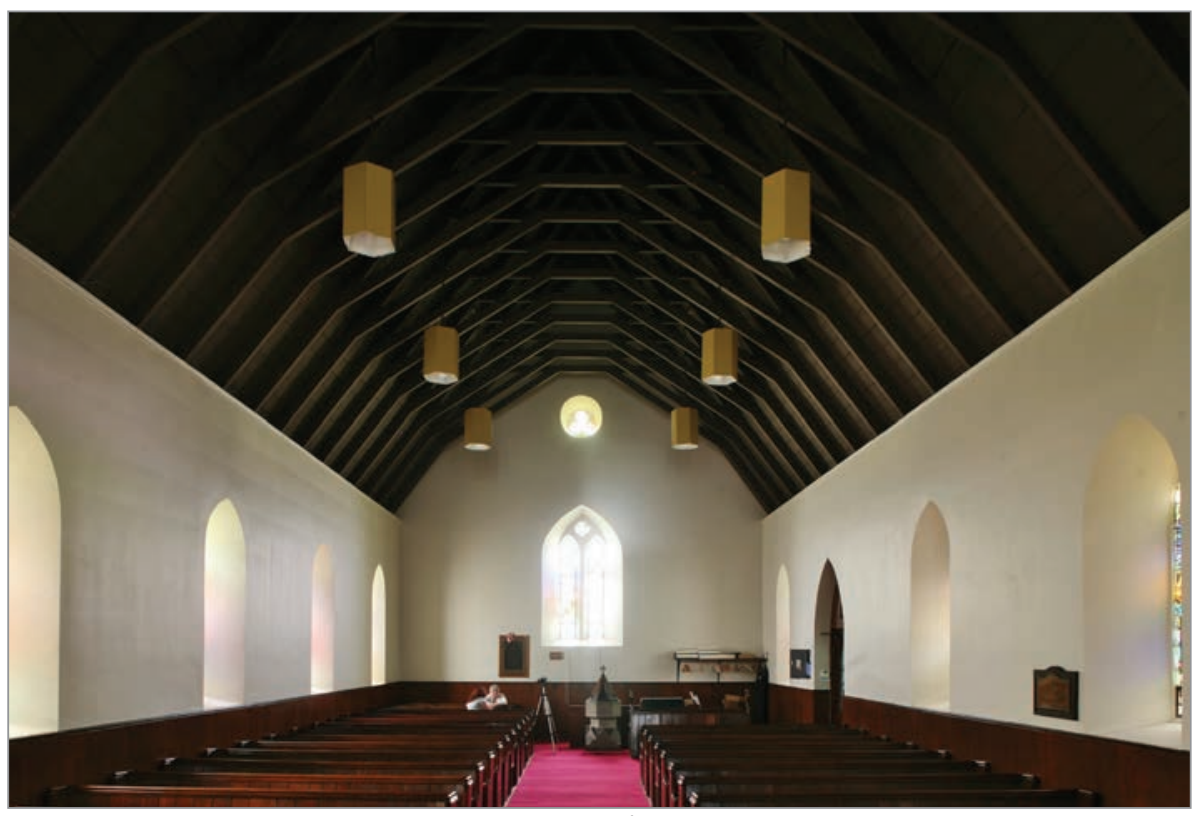

FIG. 32. NIAGARA FALLS, ALL SAINTS ANGLICAN, INTERIOR TO W. | MALCOLM THURLBY.

Gibbsian design principles. ${ }^{59}$ It comprised five bays with multi-paned rectangular windows on the ground floor surmounted by round-headed windows at gallery level. ${ }^{60}$ The façade did not have a temple-form portico as at St. Andrew's,
Niagara-on-the-Lake, but bay division and vertical articulation were provided with pilasters. The location of the two-stage tower and spire was the same in both churches, but at St. Catharines the second stage of the tower was square rather than 
octagonal as at Niagara-on-the-Lake, and had pointed belfry openings. Equally strange in an essentially classicizing building was the use of pinnacles on the angles of both stages of the tower.

\section{St. Catharines, St. George's Anglican Church}

In 1844, the Anglicans of St. Catharines employed Toronto architect John George Howard [1803-1890] to design the tower and spire and additions to the church of St. George (fig. 11). ${ }^{61}$ The façade reflects the west front of Casterton Chapel (Westmorland), illustrated in William Carus Wilson, Helps to the Building of Churches, a copy of which is preserved in the Archives of Christ's Church, Hamilton (fig. 12). ${ }^{62}$ While the modifications do not speak clearly of the medieval sources advocated by the Cambridge Camden Society in their journal The Ecclesiologist, and publications like $A$ Few Words to Church Builders, ${ }^{63}$ the application of Gothic detail is probably inspired by the desire to use the "correct" Christian style for the Anglican edifice in town rather than the essentially "pagan" Presbyterian church just along the road. ${ }^{64}$

\section{Port Robinson, St. Paul's Anglican Church}

Also in 1844, in the Anglican church of St. Paul at Port Robinson, Gibbs's tradition is once again evident, albeit translated into Gothic (figs. 13-14). The sanctuary with high altar is flanked by two quadrant-shaped rooms, probably vestries, all enclosed within a flat east wall in the manner of St. Martin-in-theFields, London. The Gothic details show no impact of the Cambridge Camden Society; instead, principles established in Commissioners' Gothic are followed as at St. Thomas's Anglican Church, St. Thomas, Ontario (1824), and, on smaller scale, at

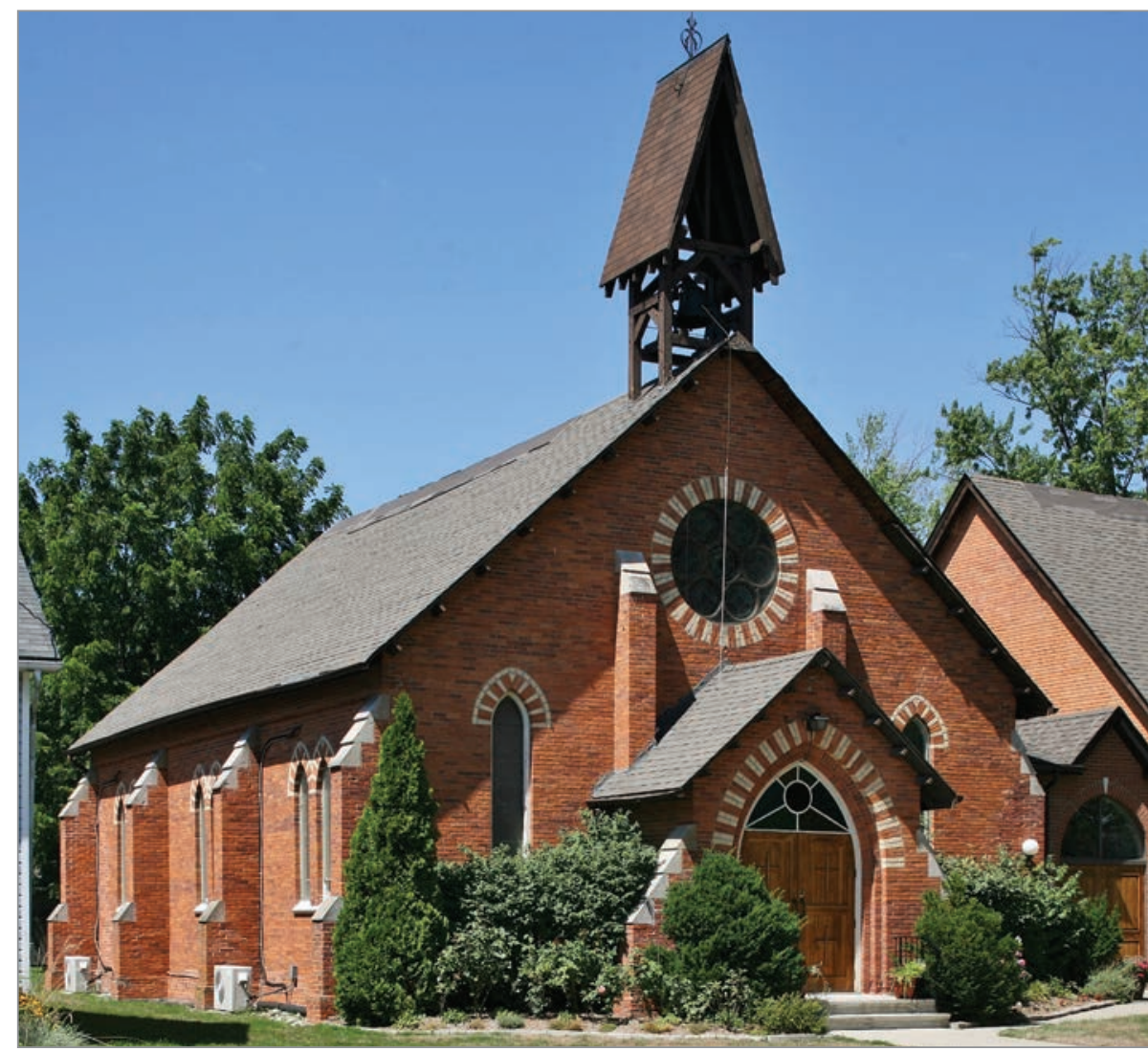

FIG. 33. PORT DALHOUSIE, ST. JOHN'S ANGLICAN CHURCH, 1868, EXTERIOR. | MALCOLM THURLBY.

Christ Church, Moulinette, Ontario (1837), now at Upper Canada Village.

\section{Thorold, Trinity Wesleyan Methodist (United)}

The design of Trinity Wesleyan Methodist (United) Church, Thorold (1845), follows the principles of St. Paul's Anglican, Port Robinson, with stone substituted for clapboard and the inclusion of a full basement for school and service rooms (fig. 15). It is significant that pointed arches are used throughout, in recognition of the proper Christian style outside the Anglican Church. As if to give authority to the acceptance of the Pointed style for Methodist churches, Frederick J. Jobson's book, Chapel and School Architecture as Appropriate to the
Buildings of Nonconformists Particularly to Those of the Wesleyan Methodists, is nothing short of a translation of Augustus Welby Pugin's True Principles for the Methodists. ${ }^{65}$ The seating of Thorold Methodist is of particular interest for its arced arrangement (fig. 16), something that became particularly popular in the 1860s, but was already used much earlier, as published in William Fuller Pocock's Designs for Churches and Chapels. ${ }^{66}$

\section{Thorold, St. John the Evangelist Anglican}

The ambitious Anglican Church of St. John the Evangelist, Thorold, was built in 1852 to the design of Kivas Tully, who arrived in Toronto from Ireland in 1844 and worked in the office of John George Howard 


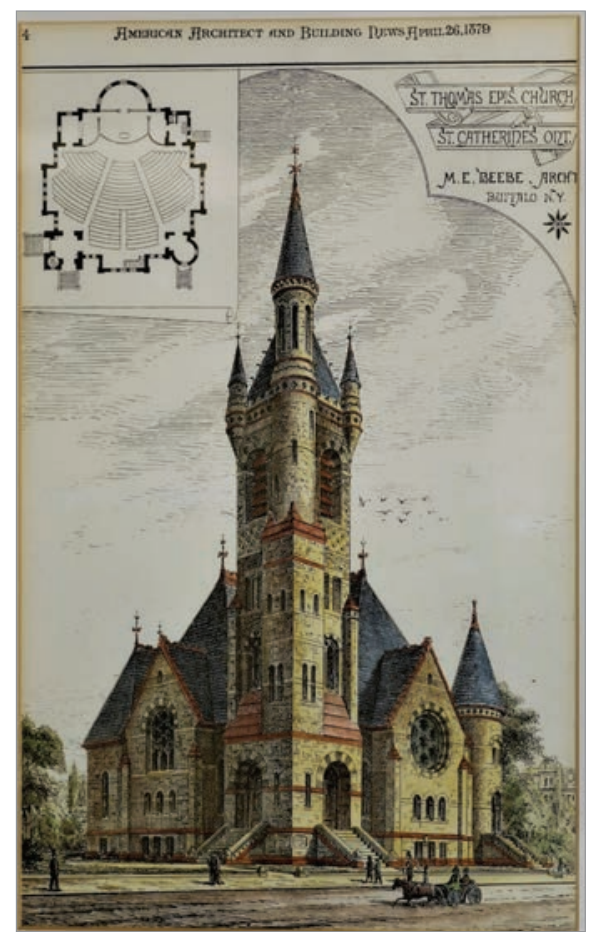

FIG. 34. ST. CATHARINES, ST. THOMAS'S ANGLICAN CHURCH, 1878, AMERICAN ARCHITECT AND BUILDING NEWS, APRIL 26, 1879, P. 4. | MALCOLM THURLBY.

(figs. 17-18). ${ }^{67}$ Many elements of the church suggest awareness of the move towards Gothic in Anglican Church design. While not revealing strict adherence to medieval models as advocated by the Ecclesiologists, the separate chancel with three lancet windows in the east wall to symbolize the Trinity follows their recommendations. The west tower projects fully at the west front in contrast to St. George's Anglican Church, St. Catharines, a feature more akin to medieval exemplars. The south porch is a later addition. The masonry is stone rubble with fictive masonry joints to simulate ashlar (fig. 19), a lack of truth removed from the canons of Pugin and the Ecclesiologists. There are open seats in the nave in contrast, for example, to the box pews in St. Andrew's, Niagara-onthe-Lake, a feature that shows the impact of the Ecclesiologists (fig. 20). ${ }^{68}$ There is a handsome hammer-beam roof with the truthful exposure of wood in sharp contrast

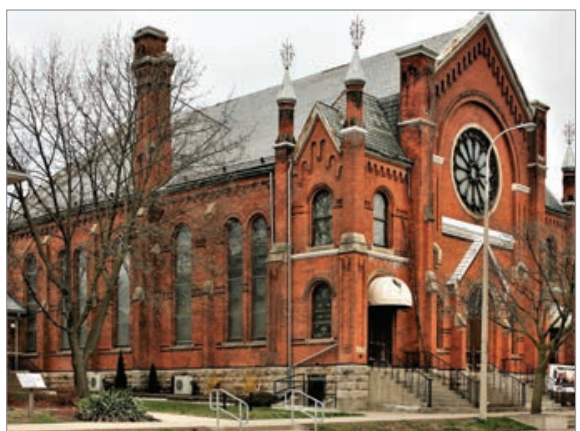

FIG. 35. ST. CATHARINES, FIRST PRESBYTERIAN, 1879, EXTERIOR. | MALCOLM THURLBY.

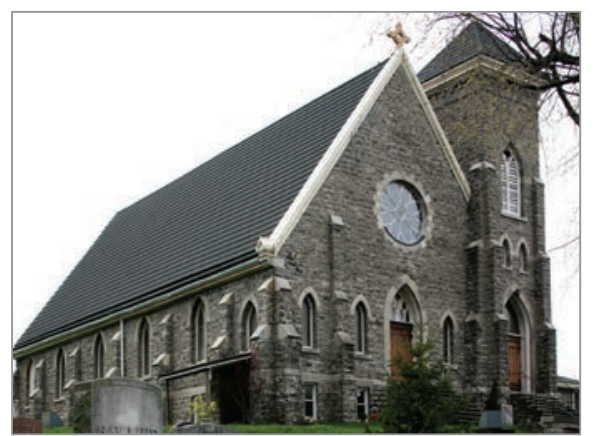

FIG. 36. FORT ERIE, ST. PAUL'S ANGLICAN, 1878, EXTERIOR. | MALCOLM THURLBY.

to the "sham" lath-and-plaster vault of Beaverdams Methodist Chapel (figs. 5 and 20). The roof is a simplified version of the hammer-beam roofs in the Norfolk churches of Trunch and Wymondham, illustrated by Raphael and J. Arthur Brandon in The Open Timber Roofs of the Middle Ages. ${ }^{69}$ Given that Ecclesiological principles indicate that the chancel should be more richly articulated and decorated than the nave, it is surprising that the chancel roof of St. John the Evangelist is much simpler than that of the nave.

\section{McNab (Grantham), Christ Church Anglican $^{70}$}

Christ Church, McNab, holds an interesting place in the history of Anglican Church architecture in Canada West in the 1850s. Designed in $1853^{71}$ by the Torontobased architect William Thomas [17991860], the church is an intriguing mix

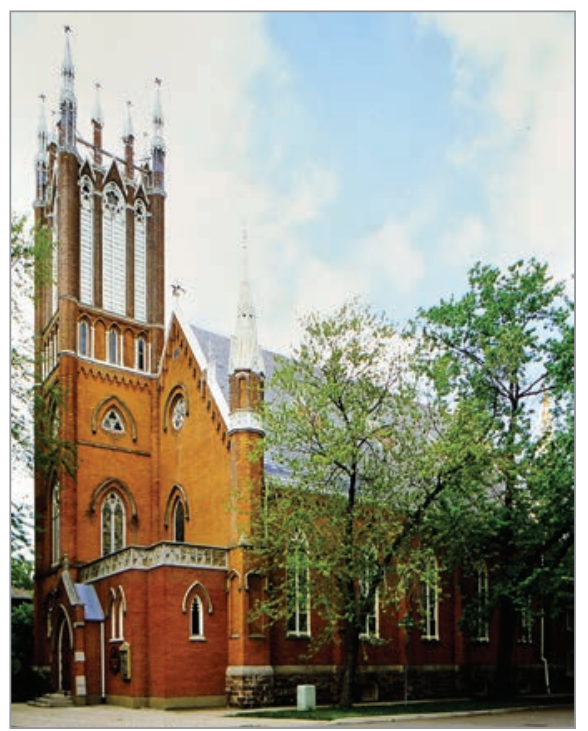

FIG. 37. ST. CATHARINES, WELLAND AVENUE METHODIST (UNITED) CHURCH, 1878, EXTERIOR. | MALCOLM THURLBY. of traditional elements and details that reveal Thomas's knowledge of the latest developments in church architecture in England. ${ }^{72}$ Christ Church stands in a large churchyard which preserves the original site and the ideal image of the Anglican Church according to the romantic notion of the Church of England in the Colonies (figs. 21-22). The church now comprises a square chancel, rectangular nave, and central west tower and spire. The style is primarily Early Pointed, although the doorways that flank the chancel in the east wall are round-headed. The exterior side walls are divided into four bays by stepped buttresses and have single lancet windows in each bay. The building material is primarily red brick with yellow brick for the nave and tower buttresses, the inner order of the nave windows, the arches of the west and east doorways, the quatrefoil frieze between the first and second storeys of the west tower, the two 
chimneys at the east end, and the tower and west façade corbel tables. The yellow brick of the buttresses ranges consistently with the red brick of the wall (fig. 23), a sure indication that the buttresses are integral with the construction of the walls and not a later addition. The chancel uses only red brick and is without buttresses, and has a steeper pitch to the roof than over the nave. It is an addition to the core of Thomas's church.

Polychrome red and yellow brick might be interpreted as a progressive High Victorian detail, but regional precedent is found in Henry Bowyer Lane's [1817-1878] Little Trinity, King Street East, Toronto (1843). Thomas also used red brick for St. Paul's Anglican Church, London (1844-1845). At the time, red brick was outlawed by the Cambridge Camden Society, yet by 1850 the material was embraced. Red brick was used by Pugin from the late 1830s in St. Mary's, Uttoxeter (Staffordshire), St. Augustine's, Kenilworth (Warwickshire), and St. Wilfrid's, Hulme, Manchester. In Upper Canada, red brick was used by Frank Wills [1822-1857] at St. Paul's, Glanford (1851?)..$^{73}$ It increased in popularity in High Victorian churches after George Edmund Street [1824-1881] called for the use of brick in town churches. ${ }^{74}$ William Butterfield's [1814-1900] All Saints, Margaret Street, London (1849), much celebrated by Ecclesiologists, is a bold expression of polychrome masonry including black brick. Butterfield used moulded stone heads in the church windows, but black brick was used for voussoirs in the clergy house. A version of this specifically High Victorian feature is emulated at Christ Church, McNab, in the nave windows where the black voussoirs are created from creosoted wood (fig. 24).

The interior of Christ Church, McNab, comprises an aisleless nave covered with a pitched roof in which the bay divisions

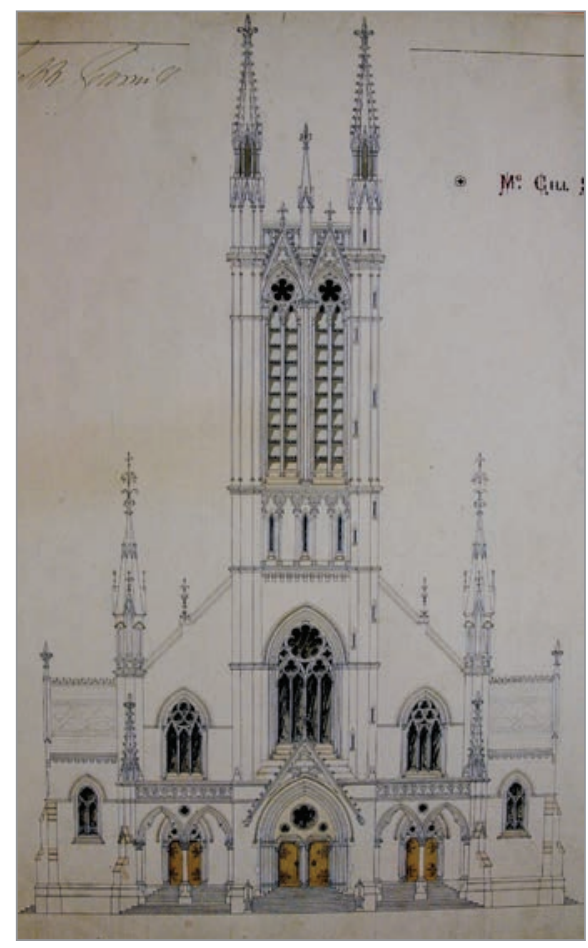

FIG. 38. TORONTO, MCGILL SQUARE, WESLEYAN METHODIST CHURCH, HENRY LANGLEY, 1870. COURTESY TORONTO PUBLIC LIBRARY, BALDWIN ROOM.| MALCOLM THURLBY.

are created by dark wooden transverse beams carried on wall corbels and dark wall beams and ridge ribs (fig. 25). Of the four windows on the lateral walls, only the western three illuminate the nave. The eastern windows light small rooms entered by pointed doorways at the east end of the nave that flank the chancel and are also entered from the exterior by roundheaded doorways (fig. 22). They probably served as vestry and robing rooms in Gibbs's tradition, as at Marylebone Chapel, St. Peter, Vere Street, London. The arrangement is broadly allied to St. Paul, Port Robinson (1844), although the curved walls towards the nave in the latter are closer to Gibbs's St. Martin-in-the-Fields. Holy Trinity Anglican, Georgetown, Prince Edward Island, has flanking rooms which, like the others listed, are within a flat east wall in the Gibbs tradition. ${ }^{75}$ This would have been the arrangement at $\mathrm{McNab}$ before the extension of the chancel to

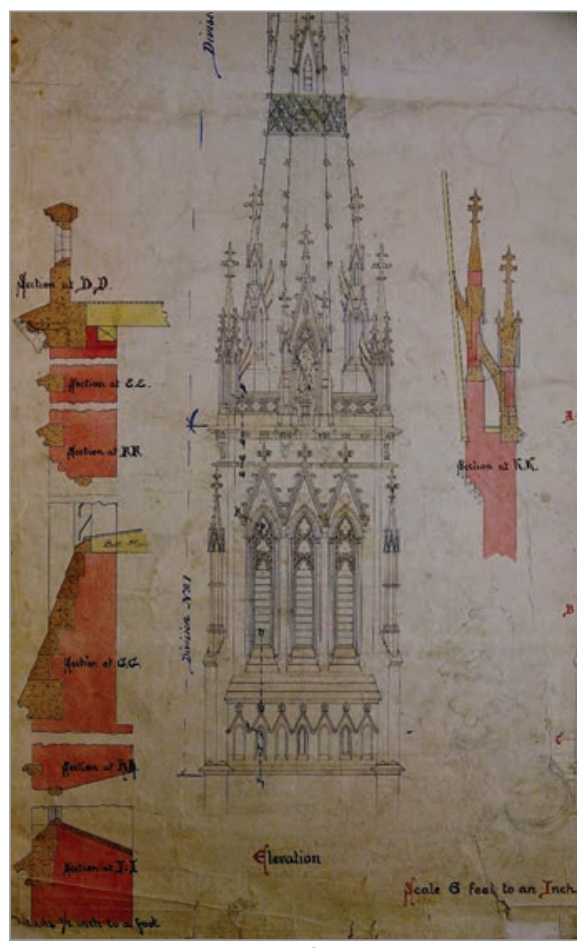

FIG. 39. TORONTO, ST. MICHAEL'S CATHOLIC CATHEDRAL, TOWER, HENRY LANGLEY, 1865. COURTESY TORONTO PUBLIC LIBRARY, BALDWIN ROOM. | MALCOLM THURLBY.

provide a more correct design according to the principles of the Ecclesiologists.

The roof exhibits some elements of ecclesiology based on knowledge of medieval Gothic originals, as published in John Henry Parker's Glossary and the Brandons' The Open Timber Roofs of the Middle Ages. ${ }^{76}$ It is, in sharp contrast, flat or vaulted lath-and-plaster in the Gibbs tradition. The wall posts, wooden transverse and ridge ribs, and relatively low pitch follow Perpendicular Gothic rather than Decorated Gothic principles. The wooden panels are much larger than in medieval roofs, which would have been further sub-divided by ribs.

In contrast to the box pews in St. Andrew's Presbyterian Church, Niagara-on-the Lake, or more importantly in an Anglican context at Robert Wetherell's Christ's Church, Hamilton (1835), ,7 Christ Church, 


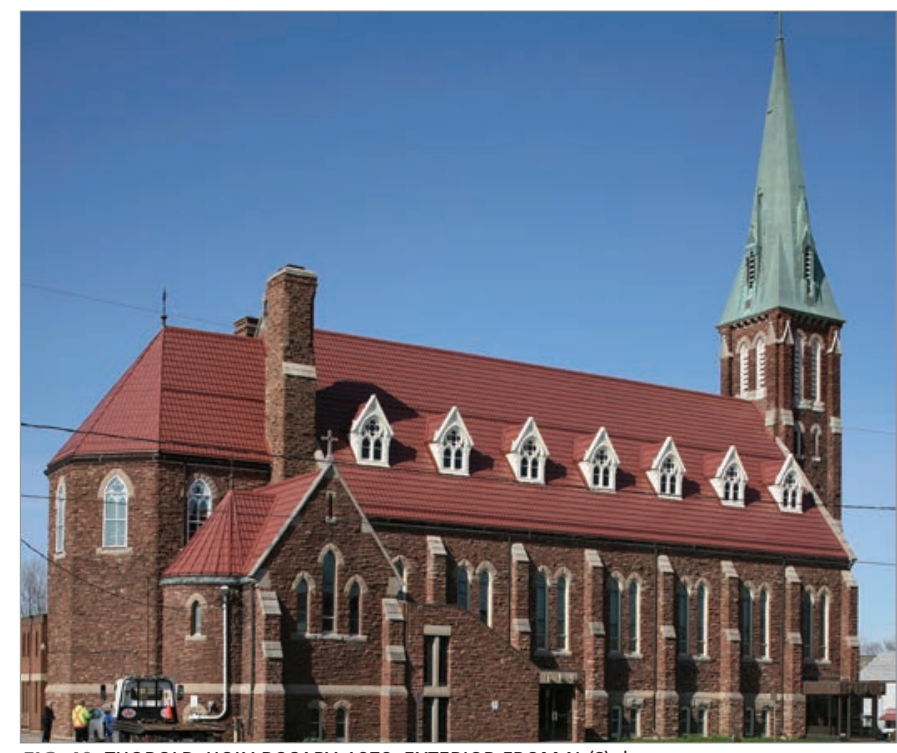

FIG. 40. THOROLD, HOLY ROSARY, 1878, EXTERIOR FROM N (S). | MALCOLM THURLBY.

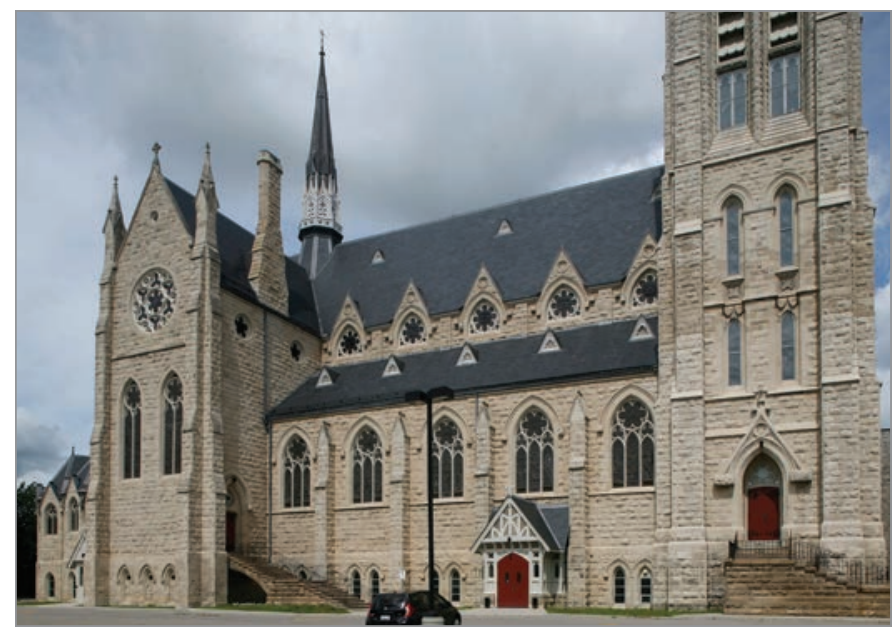

FIG. 41. GUELPH, OUR LADY OF THE IMMACULATE CONCEPTION, 1876, EXTERIOR FROM N (S). | MALCOLM THURLBY.

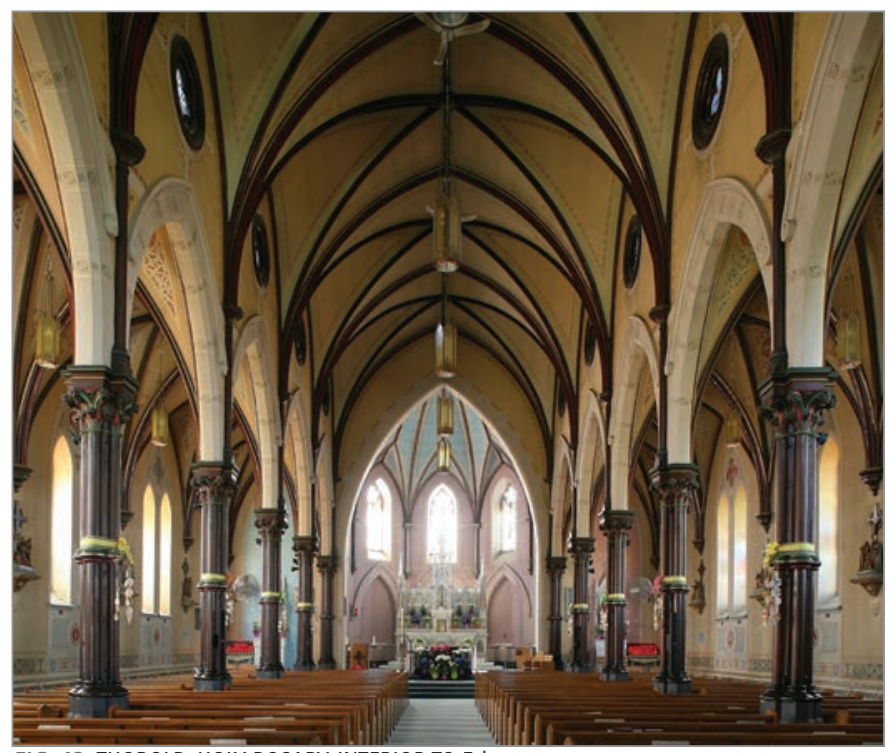

FIG. 42. THOROLD, HOLY ROSARY, INTERIOR TO E. | MALCOLM THURLBY.

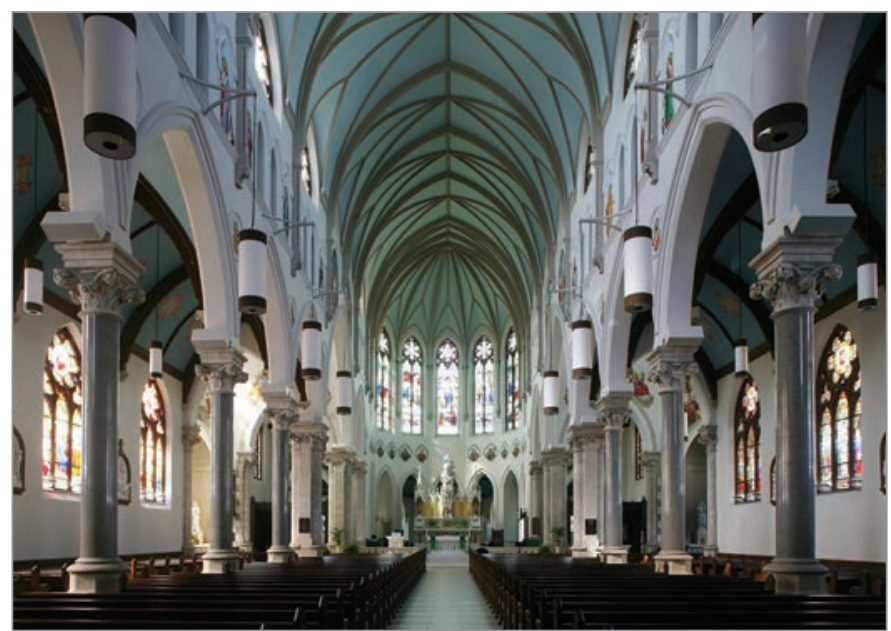

FIG. 43. GUELPH, OUR LADY OF THE IMMACULATE CONCEPTION, INTERIOR TO E (W), | MALCOLM THURLBY.
McNab, has open seats for the congregation, as strongly advocated by the Ecclesiologists and Bishop Medley. ${ }^{78}$ It is also significant that the choice of the Gothic style for McNab follows William Thomas's Gothic for the additions to Christ's Church, Hamilton. ${ }^{79}$ In the chancel extension, the triple lancet windows follow ecclesiological principles yet the lathand-plaster barrel vault does not follow Medieval Gothic models.
Niagara Falls, All Saints Anglican

All Saints Anglican Church, Niagara Falls (1856-1857), built to the design of William Hay [1818-1888], is one of the finest ecclesiological Gothic revival churches in Canada. ${ }^{80}$ Hay was brought up in the Scottish Episcopalian Church. He was a disciple of Pugin and the author of an important article on Pugin which had a significant impact on the design of Gothic churches in Canada. ${ }^{81}$ In All
Saints, we witness the assiduous application of Pugin's True Principles and Medieval authority for all aspects of Christian Pointed design. The plan comprises a rectangular chancel to the east, lower and narrower than the aisleless nave (figs. 26-27). A tower is located in the northeast angle of the chancel and nave and the main entrance is through the north porch-the south porch is a later addition. The location of the tower is the same as Hay's 1854 Christ 


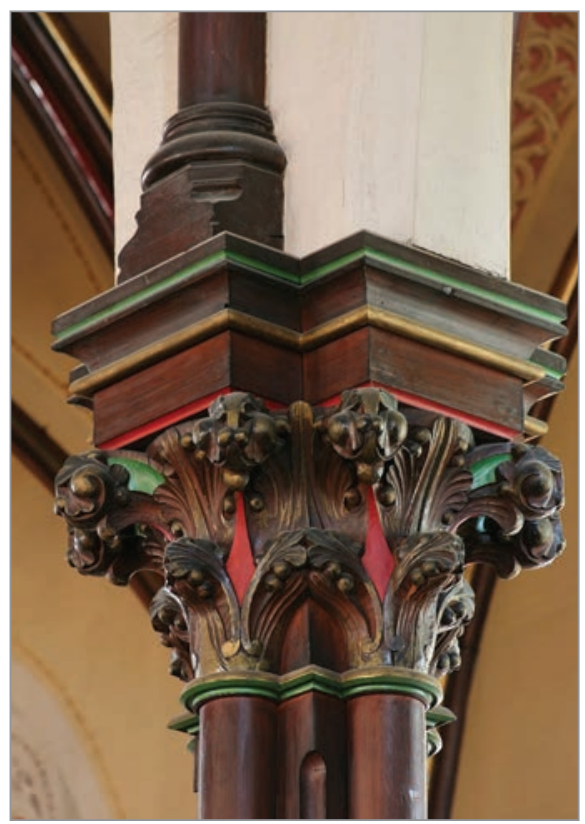

FIG. 44. THOROLD, HOLY ROSARY, ARCADE CAPITAL. | MALCOLM THURLBY.

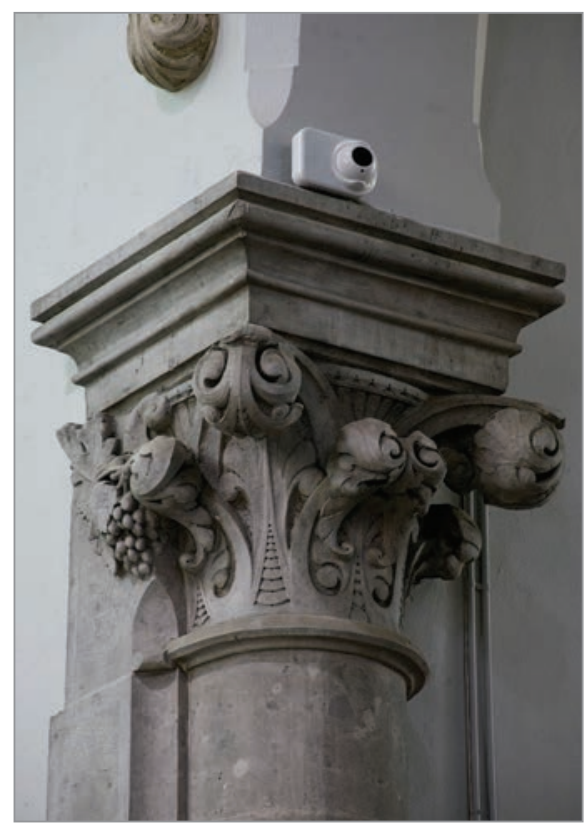

FIG. 45. GUELPH, OUR LADY OF THE IMMACULATE CONCEPTION, INTERIOR, N (S) TRANSEPT ARCH RESPOND CAPITAL. | MALCOLM THURLBY.

Church, Brampton, Ontario, which was surmounted by a broach spire, and it is likely that a spire was also intended at Niagara Falls. ${ }^{82}$ Hay uses rubble masonry with ashlar dressings and steeply pitched

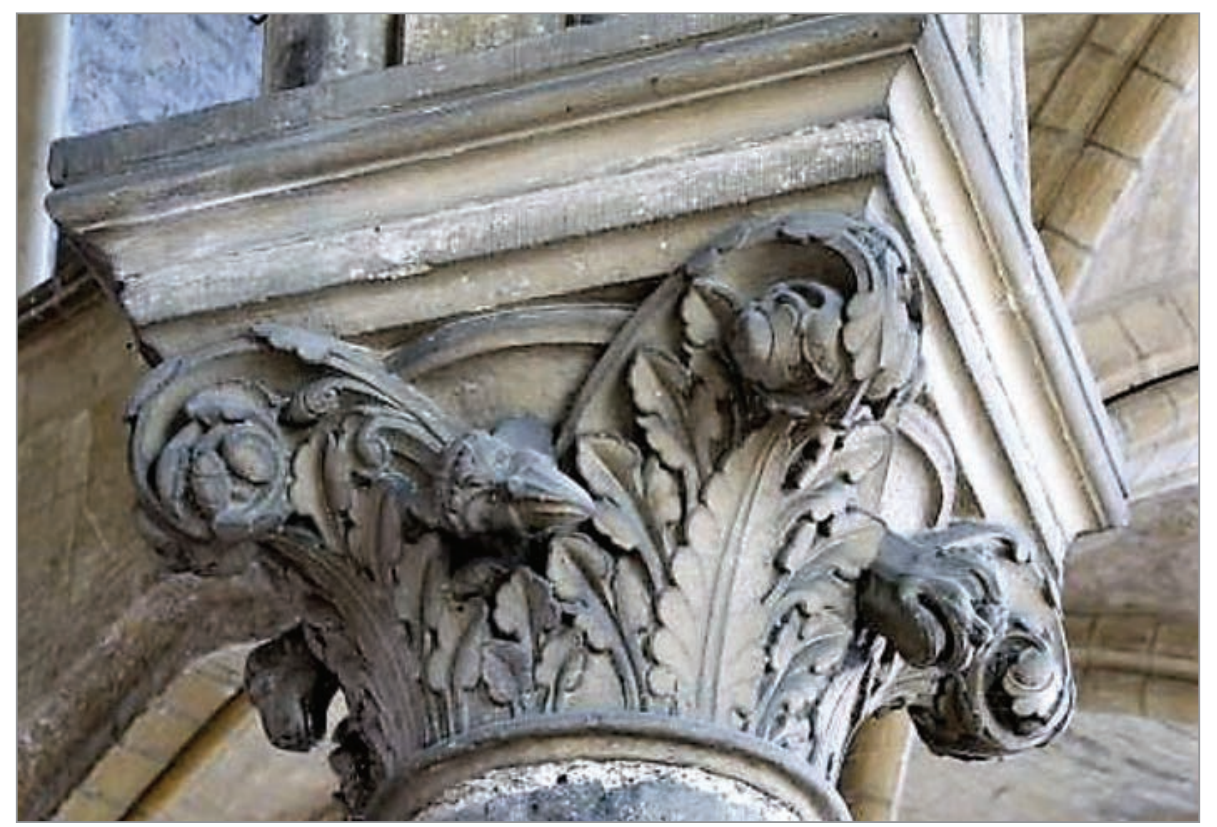

FIG. 46. SAINT-LEU D'ESSERENT, OISE, PRIORY CHURCH OF SAINT-NICHOLAS, C. 1170, APSE ARCADE CAPITAL. | MALCOLM THURLBY.

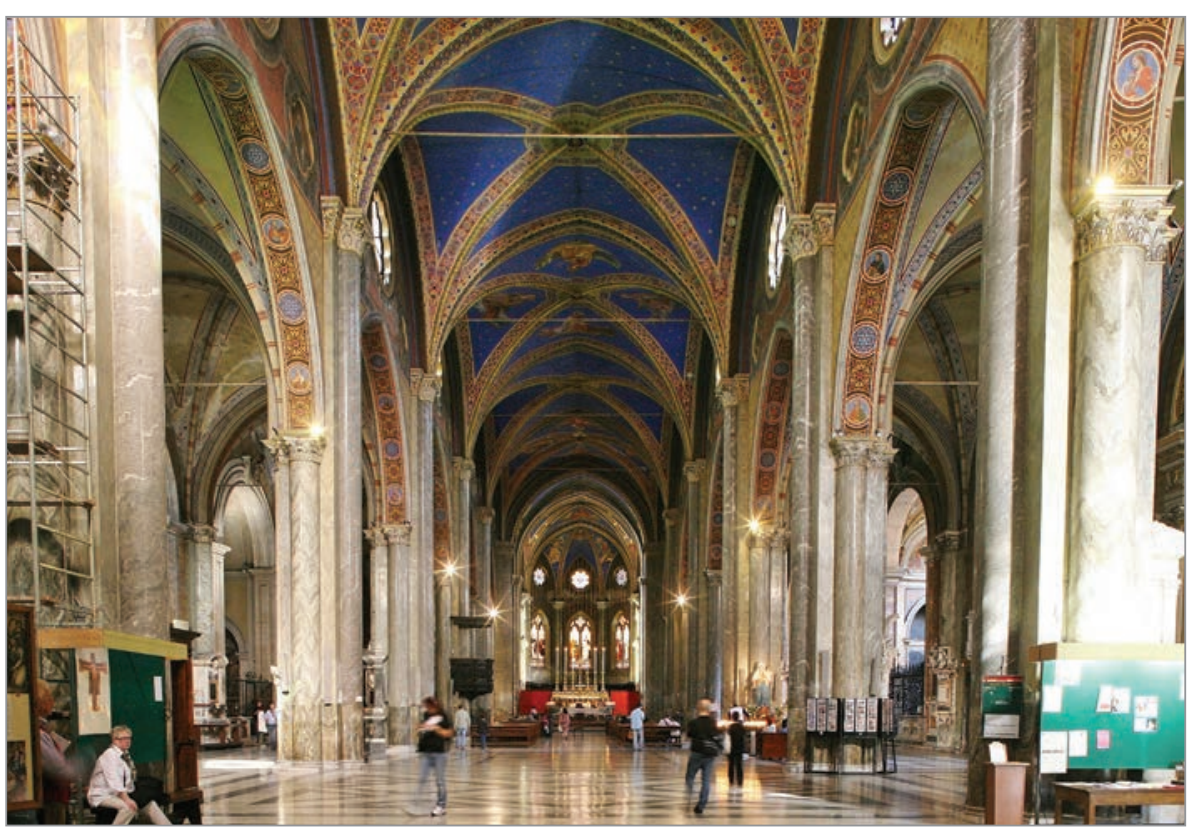

FIG. 47. ROME, SANTA MARIA SOPRA MINERVA, 1280, INTERIOR TO E. | MALCOLM THURLBY.

roofs over the chancel, nave, and north porch. The inclusion of single lancet windows conforms to the Early English Gothic style recommended by Pugin and the Ecclesiologists for small churches, except for the stepped triplet in the east wall of the chancel. Two-light plate tracery is used for the west window, the east window of the tower, and the belfry openings. There are quatrefoil windows 


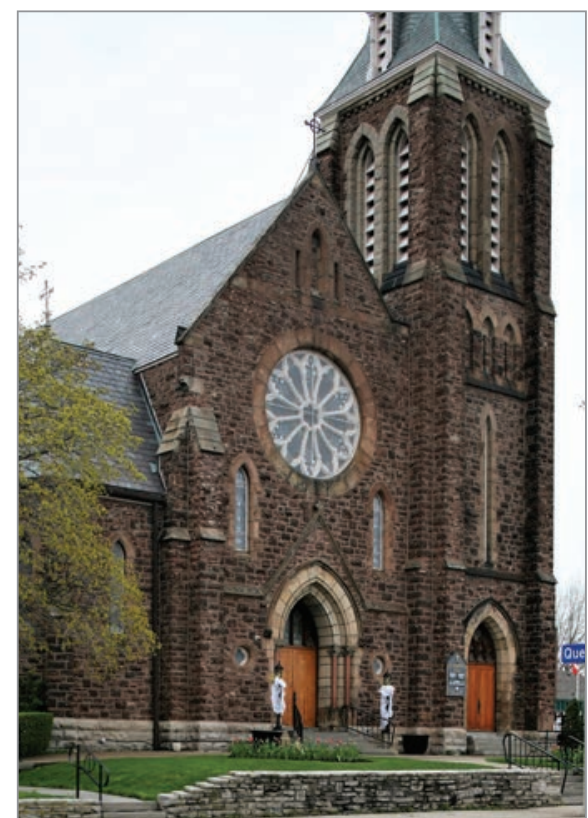

FIG. 48. NIAGARA FALLS, ST. PATRICK, 1895, EXTERIOR FROM NW (SE), POST AND HOLMES, 1895. | MALCoLm ThURLBY.

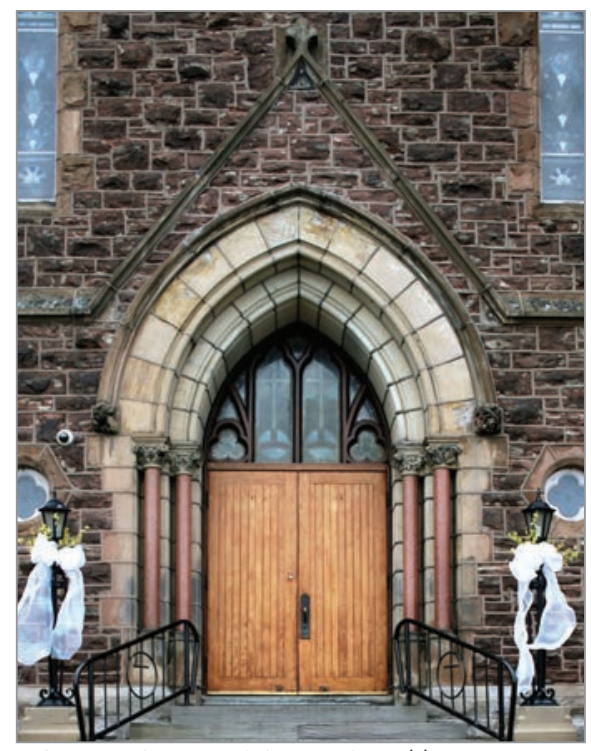

FIG. 51. NIAGARA FALLS, ST. PATRICK, W (E) DOORWAY. | MALCOLM THURLBY.

in the second storey of the tower and a trefoil window in the west gable of the nave. In contrast to the Gothic revival masonry churches in the region examined so far, All Saints does not have

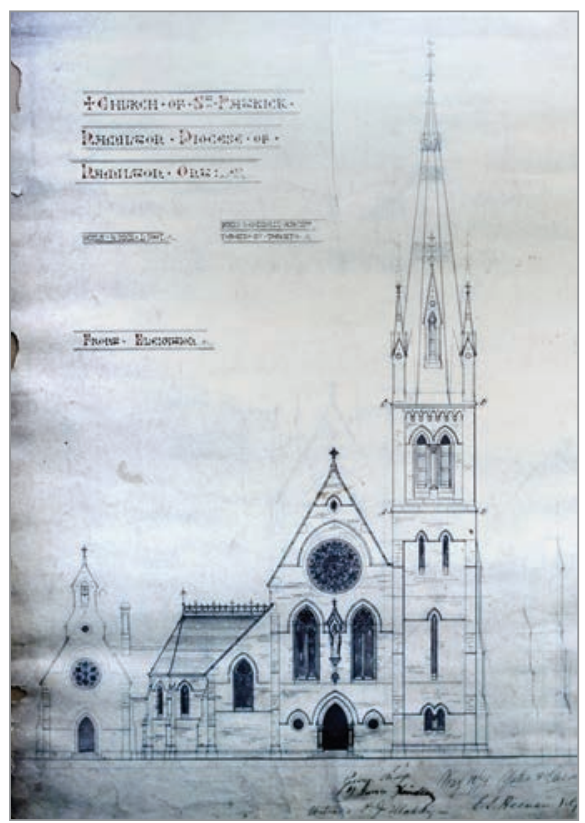

FIG. 49. HAMILTON, ST. PATRICK'S, 1875 , FAÇADE. | MALCOLM THURLBY.

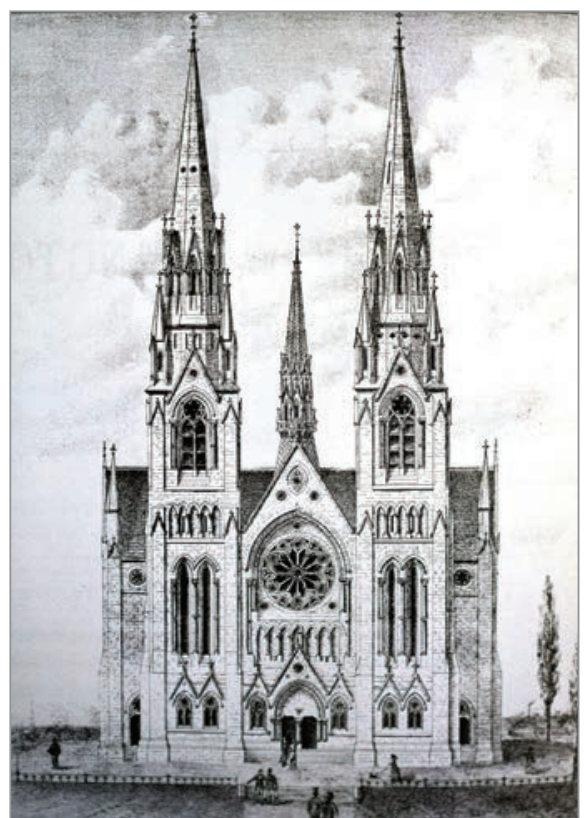

FIG. 50. GUELPH, OUR LADY OF THE IMMACULATE CONCEPTION (FORMERLY ST. BARTHOLOMEW), FAÇADE, ILLUSTRATED ATLAS OF THE COUNTY OF WATERLOO, TORONTO, ONTARIO, H. PARSELL \& CO., 1881. | MALCOLM THURLBY.

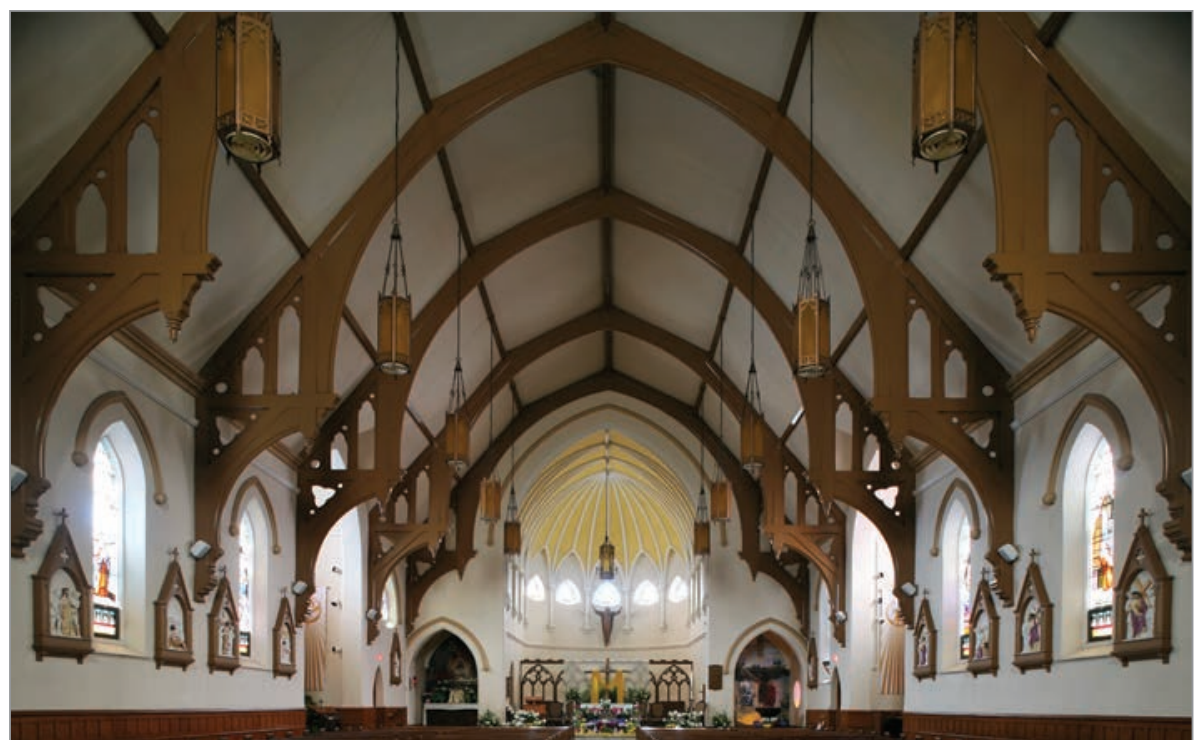

FIG, 52. NIAGARA FALLS, ST. PATRICK, INTERIOR TO E (W). | MALCOLM THURLBY.

buttresses as bay divisions or corner abutments. Hay's perception of Gothic is especially different from St. George's Anglican Church, St. Catharines, where John Howard added buttresses to the earlier fabric so as to make the whole appear more Gothic (fig. 11). And, the idea of stepped buttresses as an essential element of Gothic design is also experienced closer in date to All Saints at Holy 


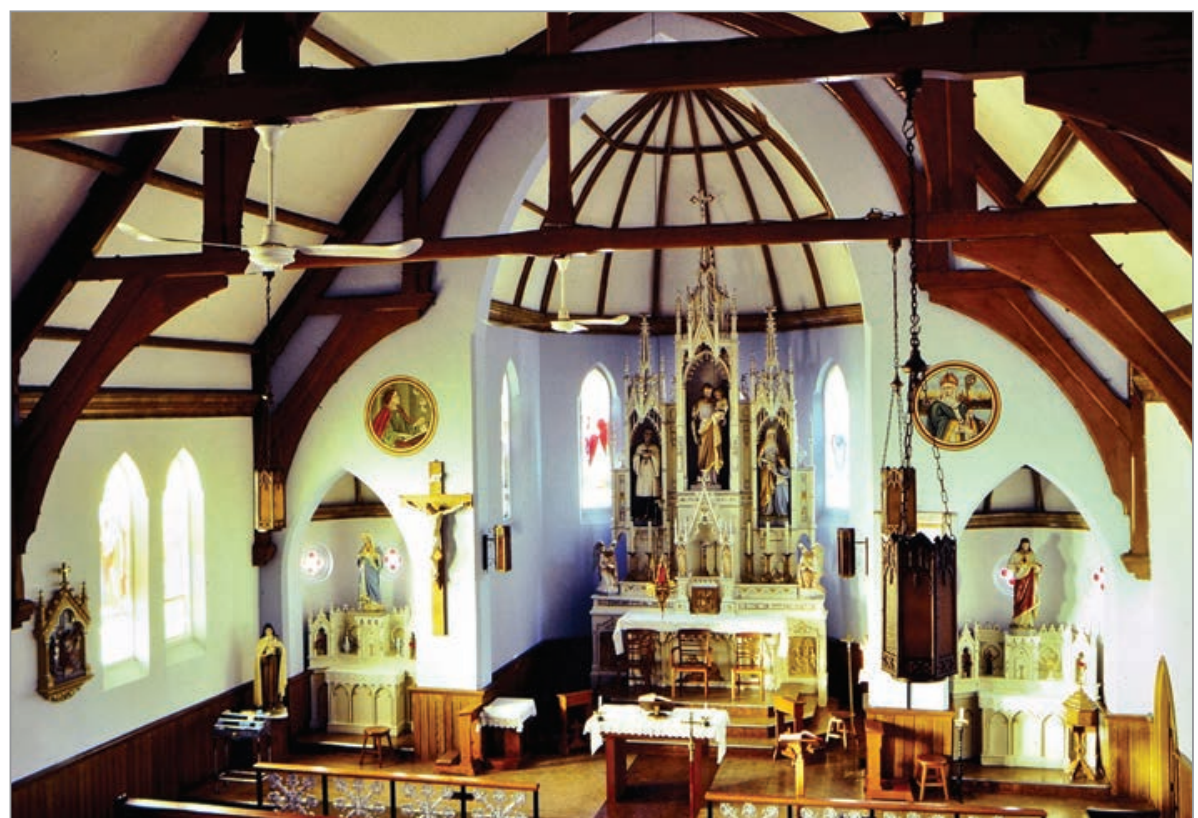

FIG. 53. MACTON, ST. JOSEPH, INTERIOR TO E. | MALCOLM THURLBY.

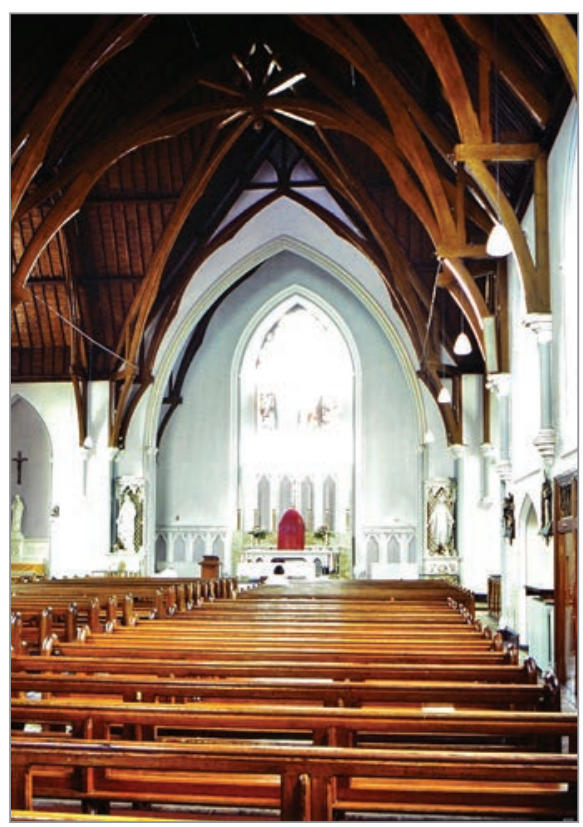

FIG. 54. GALWAY, ST. IGNATIUS, 1850, INTERIOR TO E. | MALCOLM THURLBY.
Trinity, Hawkesbury, where Thomas Fuller [1823-1898] and Chilion Jones [1835-1912] added buttresses in 1857 to the 1844 fabric of the church. ${ }^{83}$ Yet, buttresses were often absent in Pugin's churches, as at St. Augustine's, Ramsgate (Kent), and Hay did just the same in his Episcopal Church of St. Anne at Coupar Angus (Perthshire) (1848) (fig. 28). Not surprisingly, medieval precedent abounds, as in St. Romwald's Strixton (Northamptonshire), which was the subject of a monograph by Edward Barr published in $1849 .{ }^{84}$ Contrasts in masonry techniques between All Saints and St. John the Evangelist, Thorold, are also instructive. The truthful exposure of the rubble at All Saints is quite different from the fictive ashlar created with the pointing at Thorold (figs. 19, 26-27). Moreover, the regular fictive stonework of the Thorold windows is replaced by irregularly sized ashlar blocks in All Saints, exactly as in medieval Gothic and as strongly advocated by Pugin (figs. 19, 29-30). ${ }^{85}$ It is also significant that Hay opts for correct plate tracery appropriate for the Early English Gothic advocated by the Ecclesiologists for small churches, and finely carved foliage label stops enrich the belfry openings (figs. 29-30).

The interior of All Saints, Niagara Falls, is a fine display of ecclesiological design (figs. 31-32). The nave and chancel are clearly separated with a plain pointed arch and both are roofed with cross-beam construction with the wood truthfully exposed. The design of the nave roof is remarkably close to the nave of St. Michael's Church, Longstanton, one of the favourite model churches of the Ecclesiologists and published by the Brandons. ${ }^{86}$ There are two steps up to the chancel, a further step to the sanctuary, and another on which the altar is placed. The seats are open and the octagonal stone font is located at the west end of the nave close to the main entrance from the north. As on the exterior, contrast with St. John the Evangelist, Thorold, is instructive to highlight ecclesiological principles applied by Hay. Specifically, the "sham" wood and plaster detailing of the Thorold chancel arch is abandoned by Hay at All Saints for a simpler truthful appearance (figs. 20 and 32).

\section{Port Dalhousie, St. John's Anglican Church}

On William Hay's departure from Toronto for Halifax, Nova Scotia, in 1862, his former business partner, Thomas Gundry [1830-1869], continued the Hay practice in partnership with Hay's former pupil, Henry Langley [1836-1907], with Gundry in charge of the business side and Langley producing the designs. St. John's Anglican Church, Port Dalhousie (1868), is the one design from this firm in the Niagara region (fig. 33). It is a reserved exercise in High Victorian polychrome with red and yellow brick, and stone weatherings on the buttresses. Langley follows Hay in using lancets for the small church. The round window in the gable 


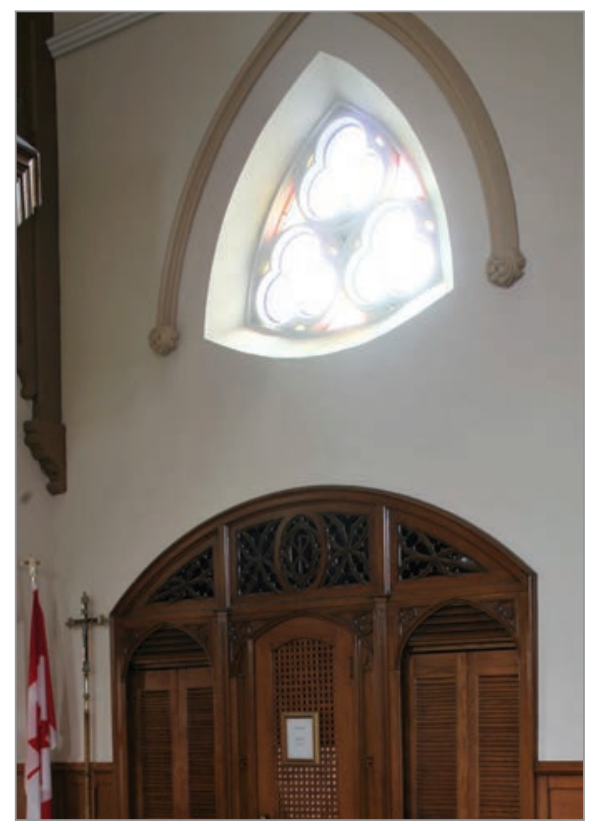

FIG. 55. NIAGARA FALLS, ST. PATRICK, INTERIOR, PENULTIMATE N (S) BAY. | MALCOLM THURLBY.

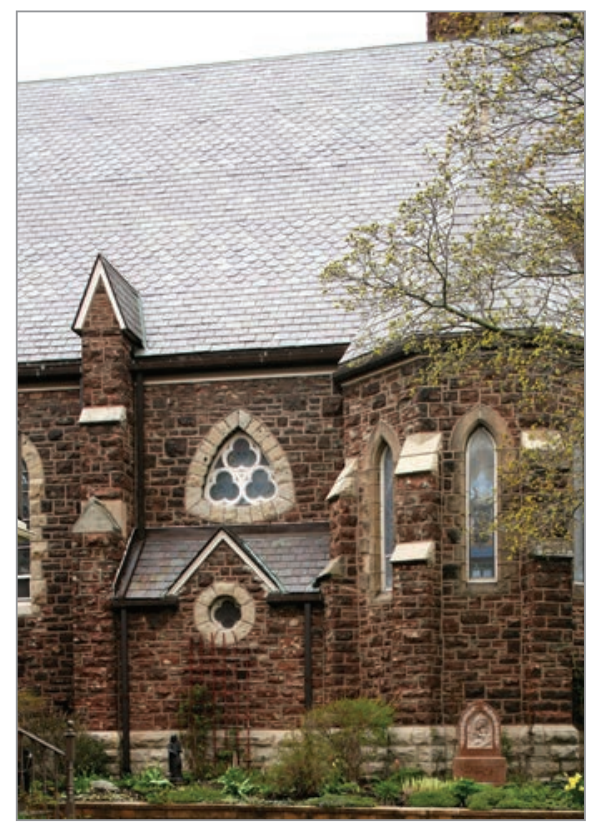

FIG. 56. NIAGARA FALLS, ST. PATRICK, EXTERIOR, CONFESSIONAL AND BAPTISTERY. | MALCOLM THURLBY.

of the west front is borrowed from Hay's Trinity Anglican Church, Zorra (1861). The proportions of Langley's design differ from Hay's aisleless naves. Instead of following his master's designs, he takes St. Michael's Church, Longstanton (Cambridgeshire), as his starting point for the broader façade with a pair of stepped buttresses to articulate a narrow central bay which conforms to the width of the double-arched and gabled stone belfry on top of the gable. For Port Dalhousie, Langley substitutes a narrower, wooden single-arched belfry. He also breaks away from the interior division of Longstanton with nave and aisles to create a single space. Like Hay's All Saints, Niagara Falls, Langley uses a plain pointed arch to divide the nave and chancel, and triple lancet windows in the east wall of the chancel. Unlike Hay, he opts for paneled, rather than open-timber roofs for both nave and chancel.

\section{St. Catharines, the Anglican Church of St. Thomas}

Something very different in Anglican Church design is found at St. Thomas's Anglican Church, St. Catharines (1879), by Buffalo architect Milton Earl Beebe [1840-1923]. ${ }^{87}$ Rather than the basilican norm and Gothic style of Anglican churches, St. Thomas is centrally planned and Romanesque. The original conception is recorded in the American Architect and Builder, April 26, 1879 (fig. 34), with arced seating normally associated with Baptist, Methodist, and Presbyterian churches in which emphasis is on the word rather than ritual. St. Thomas is Low Church as opposed to High Anglican or AngloCatholic Church. The Romanesque is not the Lombard-inspired version encountered in William Thomas's Free Church (Grace) Presbyterian at Niagara-on-theLake or First Presbyterian in St. Catharines (1879) (fig. 35), but the Romanesque of the American architect Henry Hobson Richardson [1838-1886]. Candace Iron ${ }^{88}$ has made comparisons with a proposed and finished design of Richardson's Trinity Church, Boston (1872-1877), to which may be added his Brattle Square (Unitarian) Church, Boston (1870-1872), especially for the tall angle tower and relatively squat façades with rose windows. The detail of the small angle turrets on the tower with corbelled form and sharp pinnacles look to Richardson's State Asylum in Buffalo, New York (1871). St. Thomas's Church was created for a breakaway congregation from St. George's and both the plan and Richardsonian Romanesque style are distinct expressions of the split from High Church Anglicanism and its Gothic image.

\section{Fort Erie, St. Paul's Anglican}

Beebe also designed St. Paul's Anglican Church in Fort Erie in 1878, which was rebuilt after a fire in 1892 (fig. 36). It stands in sharp contrast to St. Thomas Church, St. Catharines. The Gothic style and basilican plan are in accordance with the Anglican norm. However, in contrast to All Saints, Niagara Falls, there is no external expression of the division of nave and chancel, although precedent for this may be cited in Hay's St. George's Anglican, Pickering, Ontario (1856).

\section{St. Catharines, Welland Avenue Methodist (United) Church}

A very different expression of Gothic is experienced in Welland Avenue, Methodist (United) Church (1878), St. Catharines, by Sidney Rose Badgley [1850-1917] (fig. 37). ${ }^{89}$ Badgley apprenticed to Richard Windeyer [1831-1900] between 1871 and 1875, when Windeyer practiced in Toronto from 1871, and in Hamilton with Joseph Savage from July 1873 until January 1875. The elevation is distinctly different from that of the Anglican churches examined above. Specifically, the height of the sanctuary is far greater than an Anglican nave so as to facilitate the inclusion of galleries 
inside; something quite unacceptable in a High Church Anglican design. While the tall windows add to the impression of height to the building, they do not truthfully express the interior division of aisle and gallery, yet such matters were of no concern to the Methodists. Badgley's monumental edifice is a bold statement of Methodist presence in St. Catharines, openly vying with the new Anglican St. Thomas, First Presbyterian, and perhaps most significantly, St. Paul's First Methodist (1861-1870), in the city. ${ }^{90}$ As such, it is in keeping with the trend in Methodist, Presbyterian, and Baptist churches in the last third of the nineteenth century to build far grander churches than earlier in the century, an equivalent to what Christopher Wakeling has called "metropolitan super chapels" in England. ${ }^{91}$ Indeed, notions of cathedral grandeur are expressed in contemporary descriptions of Fort Massey Presbyterian Church, Halifax (1870), and Metropolitan Methodist, Toronto (18701872). ${ }^{92}$ It would seem that the "cathedral" status of Metropolitan Methodist appealed to Badgley and the Welland Avenue Methodist building committee, because Badgley's design owes more to it than to Savage and Windeyer's recently completed Zion Tabernacle in Hamilton. ${ }^{93}$ Zion Tabernacle employs amphitheatrical seating and, while the seating in Welland Avenue Methodist is arced, Windeyer's plan is basilican and divided into a nave and aisles with cast-iron columns carrying lath-and-plaster rib vaults. There is a full gallery on three sides of the church. The articulation of the southwest tower, especially the top two stages, repeats many details from Henry Langley's Wesleyan [Metropolitan] Methodist and his 1865 design for the completion of the tower of St. Michael's Catholic Cathedral in Toronto (figs. 37-39).

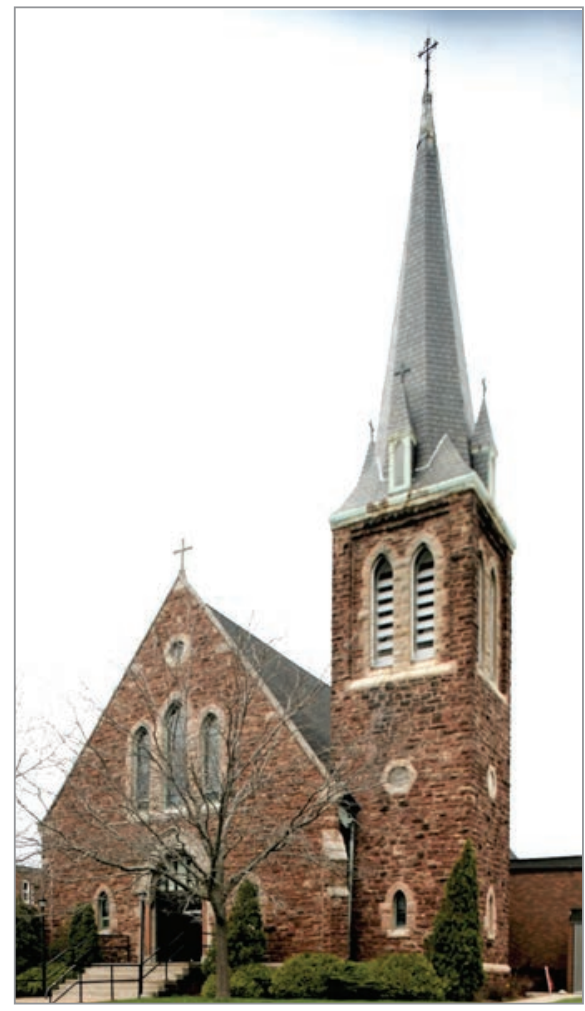

FIG. 57. MERRITTON, ST. PATRICK'S, 1898-1899, EXTERIOR FROM W. | MALCOLM THURLBY.

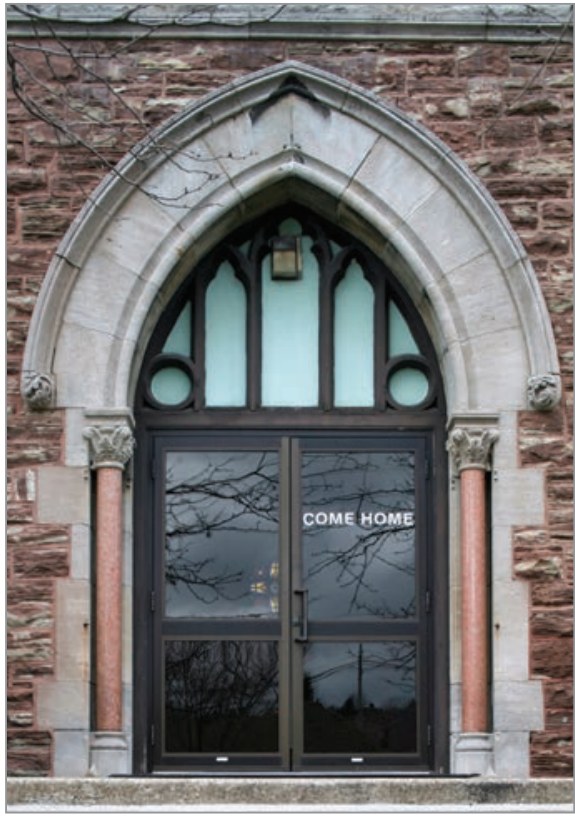

FIG. 58. MERRITTON, ST. PATRICK'S, W DOORWAY. | MALCOLM THURLBY.

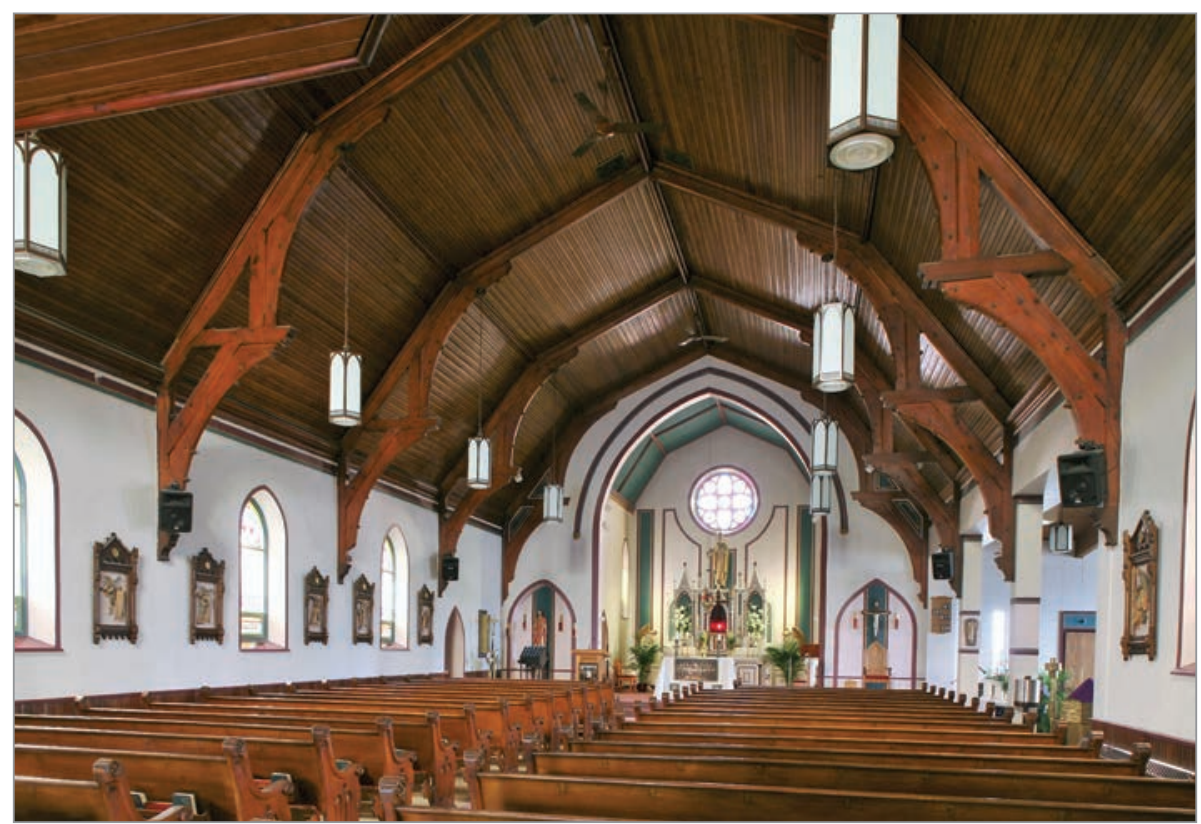

FIG. 59. MERRITTON, ST. PATRICK'S, INTERIOR TO E. | MALCOLM THURLBY. 


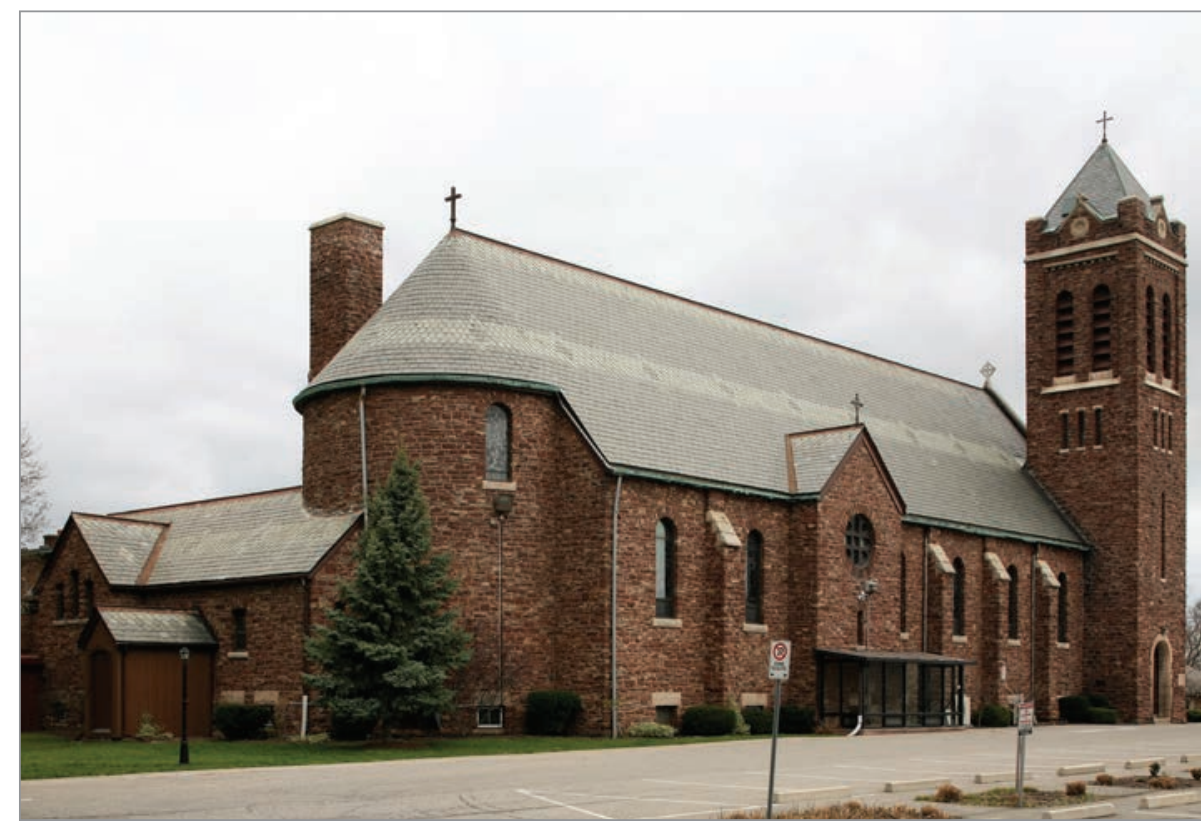

FIG. 60. ST. CATHARINES, ST. MARY OF THE ASSUMPTION, 1912-1913, EXTERIOR FROM NE (SE). | MALCOLM THURLBY.

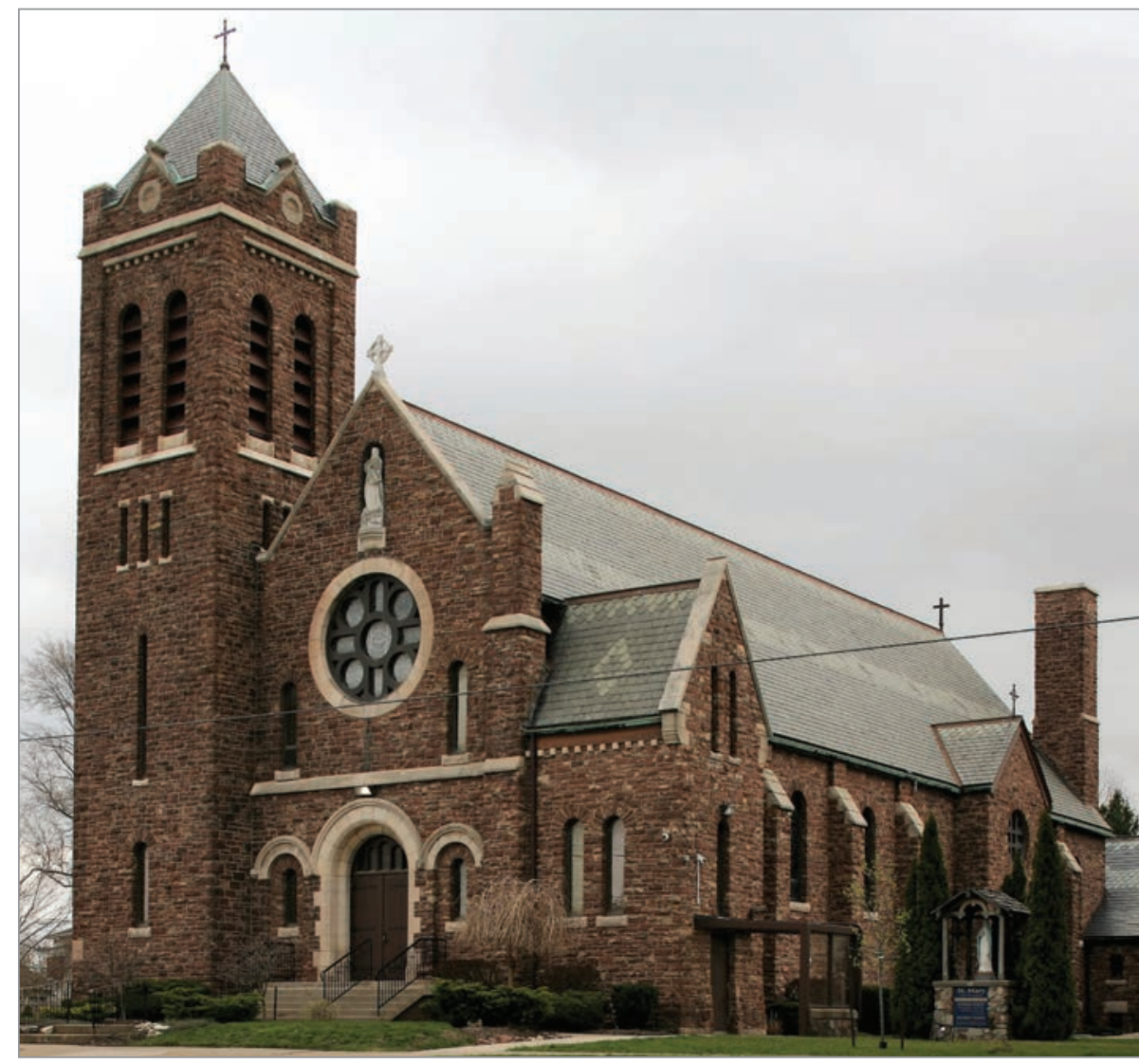

FIG. 61. ST. CATHARINES, ST. MARY OF THE ASSUMPTION, EXTERIOR FROM NW (NE). | MALCOLM THURLBY.

\section{Thorold, Holy Rosary}

The work of Joseph Connolly [18401904], renowned pupil of James Joseph McCarthy [1817-1882], the so-called Irish Pugin, who became the chief architect for the Roman Catholic Church in Ontario, is represented in the Niagara region by Holy Rosary, Thorold (1878)..$^{94}$ The church is located on the hill on the west side of town, across the valley from the Anglican St. John the Evangelist on the east side, and is clearly intended as a monumental counterpart to the Anglican presence (fig. 40). Connolly uses hammer-dressed stonework throughout with limestone dressing for windows, doorways, and buttress weatherings. There is a west tower with a broach spire and lucarnes, and a polygonal apsidal sanctuary and dwarf transepts each with an apsidal chapel to the east. The design may be seen as a simplified version of Connolly's magnum opus, the Church of Our Lady of the Immaculate Conception (formerly St. Barnabas, and later St. Bartholomew after its consecration), at Guelph (18761888) (fig. 41). ${ }^{95}$ The polygonal east apse is a reduced version of the apseambulatory plan with radiating chapels at Guelph, a formula that Connolly later used for St. Peter's, London (1880), St. Mary's, Bathurst Street, Toronto (1885), ${ }^{96}$ St. Michael's, Belleville (18861888), amongst others. ${ }^{97}$ The Thorold transepts and chapels are lower versions of Guelph. Both churches have full basements. Thorold has a single western tower instead of the two at Guelph, and a simpler broach spire rather than the early French Gothic towers and spires at Guelph, which were taken from McCarthy's Monaghan Cathedral (1861). The dormer windows are adapted from the gabled clerestory at Guelph, a necessary change because of the use of wooden arcades at Thorold (fig. 42), which would not support a masonry clerestory. Connolly also 
used such dormers earlier at St. John the Evangelist, Arthur, Ontario (1874), ${ }^{98}$ and, better known, in the additions to St. Michael's Catholic Cathedral, Toronto.

Inside Holy Rosary, the exquisitely carved acanthus capitals of the main arcades follow Guelph (figs. 42-45) and ultimately early French Gothic models as at the priory church of Saint-Nicholas, SaintLeu d'Esserent (Oise) (c. 1170) (fig. 46), and as used by McCarthy at Monaghan Cathedral. ${ }^{99}$ The blind arches in the apse follow the apse arcade at Guelph and may be traced to Monaghan Cathedral, and the pattern of the apse rib vault also follows the same precedent albeit with lath-and-plaster cells rather than planks. Other aspects of the Thorold elevation speak of different associations. In contrast to Guelph or Monaghan, quatrefoil piers replace granite columns, quadripartite rib vaults are used in the nave and aisles rather than the sexpartite vault with ridge ribs at Guelph, wall shafts on bases on the abaci of the main arcade capitals rather than corbelled shafts at Guelph, and round clerestory windows replace pointed windows. The associations speak of the Roman Gothic of Santa Maria sopra Minerva, Rome (1280) (fig. 47), so as to emphasize the Roman-ness of the Roman Catholic church while keeping the Christian pointed style. Whether the association was devised by Connolly or came at the suggestion of the building committee is a moot point, but it seems that given the popularity of Santa-Maria sopra Minerva references in Catholic churches in Canada and the United States, not least in the work of Patrick Charles Keely [18161896], it is likely that it was requested by the patron. That this is indeed the case is suggested by Connolly's addition of lath-and-plaster rib vaults to St. Mary's, Owen Sound (1876), and to the Church of the Immaculate Conception, Formosa (1880). ${ }^{100}$ Parenthetically, Connolly's

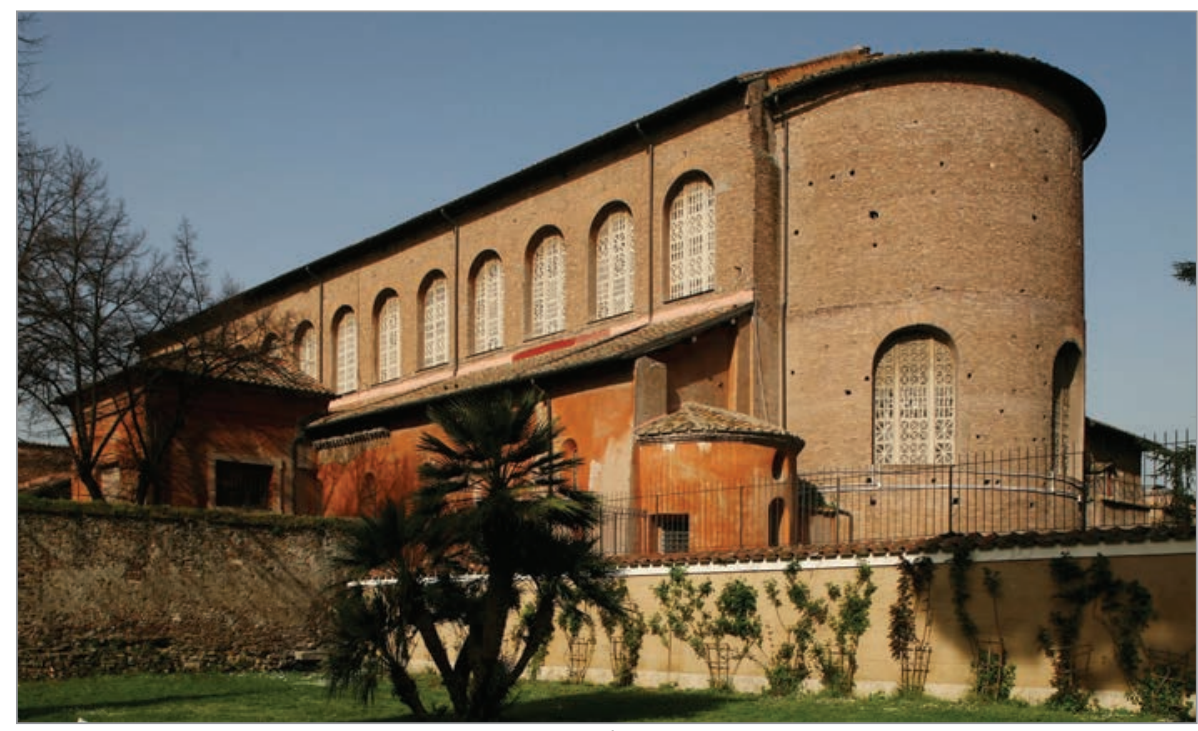

FIG. 62. ROME, SAN CLEMENTE, 422-432, EXTERIOR FROM SE. | MALCOLM THURLBY.

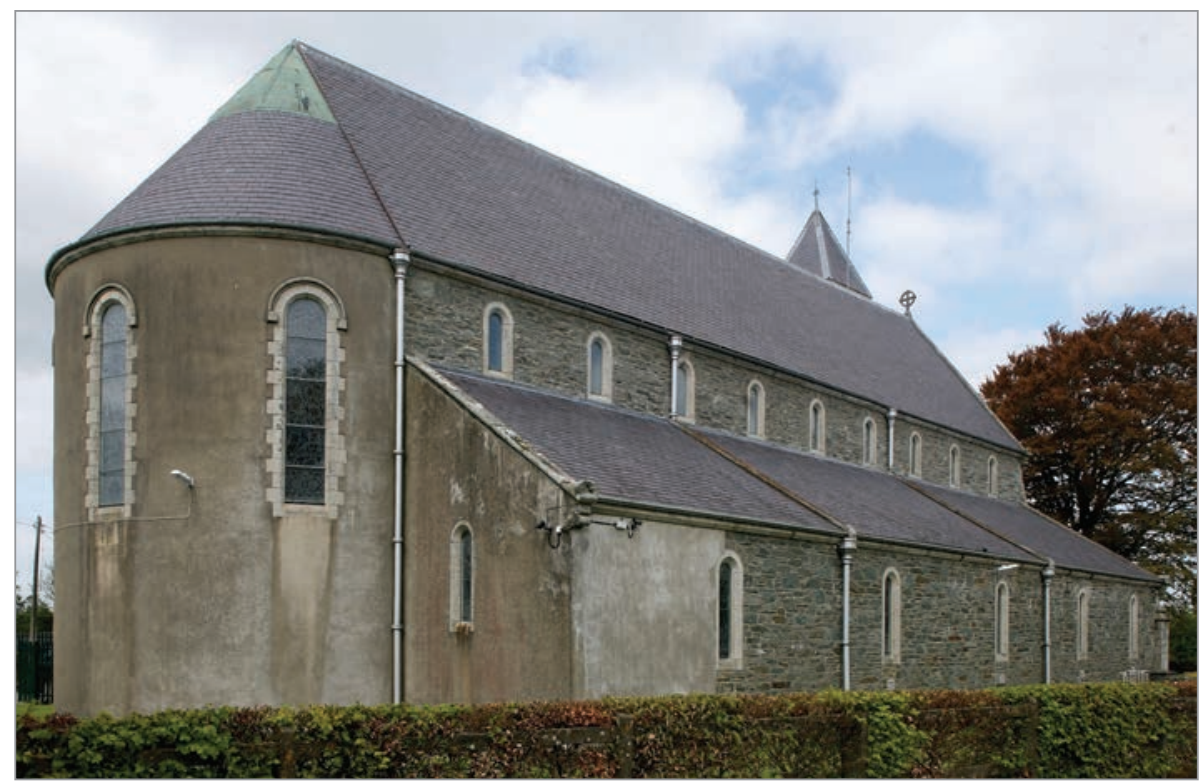

FIG. 63. BALLITORE (CO. KILDARE), ST. LAURENCE, 1860, EXTERIOR FROM NE. | MALCOLM THURLBY.

adaptability for patrons' demands is evident in his Roman Renaissance churches of St. Joseph, Chatham, Ontario (1886), and St. Paul's, Queen and Power Street, Toronto (1885). ${ }^{101}$ Whatever the exact associations, it must be emphasized that the Catholic Gothic of Holy Rosary, Thorold, is far removed from the English
Gothic of Tully's English Gothic in Thorold and William Hay's All Saints, Niagara Falls.

\section{St. Catharines, First Presbyterian}

First Presbyterian Church in St. Catharines (1877) by local architect, William Bryson Allan [1840-1911] (fig. 35), replaced the 
1834 church. ${ }^{102}$ The style is Romanesque and follows principle used in 1852 by William Thomas for Grace Presbyterian in Niagara-on-the-Lake, not least in the arched corbel tables inspired by Lombard Romanesque architecture. The monumentality is more assured than in Allan's Queen Street Baptist Church, St. Catharines (1871), which is somewhat flimsy Romanesque.

\section{Niagara Falls, St. Patrick Roman Catholic}

Connolly's legacy for the design of Roman Catholic churches in Ontario down to the 1930s is witnessed in the work of his former pupil and assistant, Arthur William Holmes [1863-1944], initially in partnership with Albert Asa Post [1850-1926] until 1895. ${ }^{103}$ The legacy is richly expressed in the Niagara region first in St. Patrick, Niagara Falls (1895), with Post who had apprenticed with Henry Langley in Toronto (fig. 48). ${ }^{104}$ The design of the church depends closely on Joseph Connolly's St. Patrick's, Hamilton (1875), ${ }^{105}$ with the southwest tower, nave façade with the pointed doorway flanked by small round windows and a rose window above, and a semi-octagonal baptistery projecting to the north from the western bay (figs. 48-49). As in Connolly's Holy Trinity, Thorold, hammer-dressed masonry is used, in contrast to the yellow brick of St. Patrick's, Hamilton. The Niagara Falls doorway has two orders rather than one as at Hamilton, and is topped with a gable created by simple string courses as in Connolly's Church of Our Lady at Guelph, where we find similar granite shafts and acanthus capitals (fig. 50-51). Unlike Hamilton, the interior of St. Patrick, Niagara Falls, is not subdivided into a nave and aisles, but is a single space with a main apse at the east end flanked by single apsidal chapels (fig. 52). The open arrangement was to become the standard for large churches by Holmes, although precedent for this is found in Connolly's smaller churches, such as St. Joseph, Macton (1878-1879), where we find the same chapel plan and the monumental hammer-beam roof (fig. 53), which in turn may be traced to McCarthy's St. Ignatius, Galway (1850) (fig. 54). ${ }^{106}$ Another detail of the design of St. Patrick, Niagara Falls, is the architectural confessional, here illustrated from the exterior immediately to the east of the polygonal baptistery and from the interior with the wooden doors (figs. 55-56). From the functional standpoint, the arrangement facilitates the removal of furniture confessionals within the aisle. Not surprisingly, the feature and design come from Connolly, as at St. James Boanarges, Kingston (1892-1893), and St. Gregory the Great, Picton (1892), amongst others. ${ }^{107}$ In turn there is the lineage through McCarthy to Pugin at St. George's Cathedral, Southwark (18411848), and St. Augustine's, Ramsgate (Kent) (1845-1852).

Just as William Hay's All Saints Anglican Church, Niagara Falls, referenced Early English Gothic models so as to recreate the correct image of the English Church in Upper Canada, so Post and Holmes assiduously apply Irish Gothic vocabulary for St. Patrick's, according to Joseph Connolly and, as his mentor McCarthy had done in St. Patrick's, St. John's, Newfoundland, in memory of the Irish motherland and in contrast to the Anglican Cathedral in St. John's. ${ }^{108}$

\section{Merritton, St. Patrick's Roman Catholic}

The very same principle is seen in Holmes's church of St. Patrick's, Merritton (18981899), ${ }^{109}$ in the southeast of St. Catharines (fig. 57). The foundation stone was laid on June 12, 1898, by the Archbishop of Toronto. Built of local mottled brown stone with Queenston limestone dressings, the design is a simplified version of St. Patrick's, Niagara Falls, with a southwestern tower and broach spire and lucarnes, a single-order central west doorway and granite columns and acanthus capitals (fig. 58), and triple lancet windows in place of the rose window at Niagara Falls (figs. 48 and 51). The aisleless nave is covered with a hammer-beam roof and at the east end the lower chancel has a paneled roof and is flanked by altars under pointed enclosing arches (fig. 59).

\section{St. Catharines, St. Mary of the Assumption Roman Catholic}

St. Mary of the Assumption Roman Catholic Church, 169 St. Paul Crescent, St. Catharines (1912-1913), is an interesting round-arched variant to the Holmes churches examined so far (figs. 60-61). ${ }^{110}$ The plan comprises an aisleless nave with a large apsidal east (south) end which is roofed at the same level as the nave, shallow, dwarf transepts off the third bay of the nave, a façade with a single doorway flanked by windows and surmounted by a rose window, a tower at the northwest (northeast) corner, and a dwarf transept to the southwest (northwest). The nave is covered with a hammer-beam roof like St. Patrick's, Niagara Falls, but with round rather than pointed transverse arches, an arrangement used by Holmes, in partnership with Post, in St. Gregory's Catholic Church, Oshawa (1894).

The choice of round rather than pointed arches is explained by the desire to be quite distinct from the Gothic Anglican Church of St. George in town. As we have seen, round arches appear in the Low Anglican Church of St. Thomas, St. Catharines, but with completely 


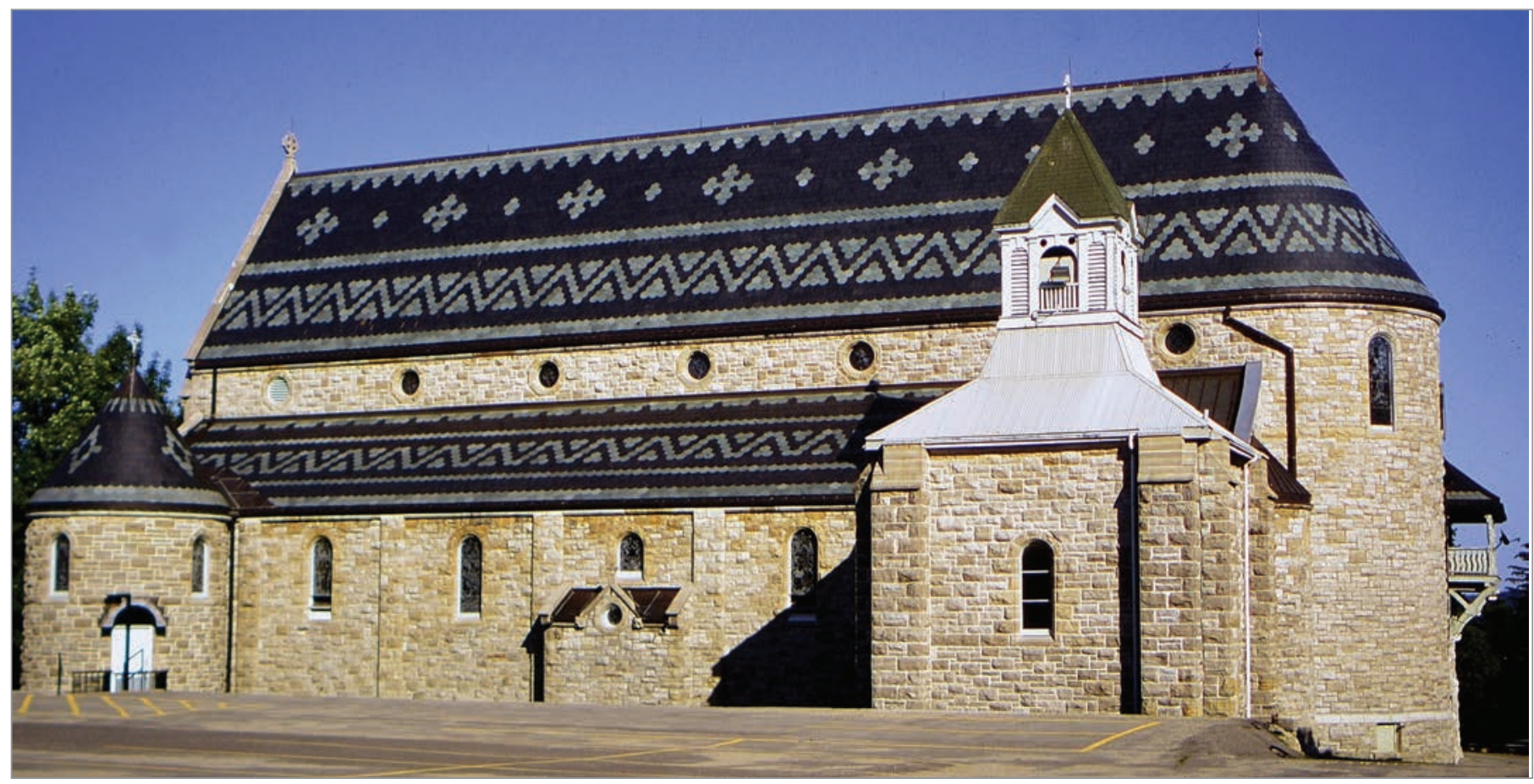

FIG. 64. GANANOQUE, ST. JOHN THE EVANGELIST, 1891, EXTERIOR FROM S (N). | MALCOLM THURLBY.

different planning and different associations from St. Mary of the Assumption. While the plan and round arches of the Low Anglican St. Thomas was different from High Anglican establishment, the basilican plan with plain semi-circular apse of the Catholic St. Mary of the Assumption seeks association with early Christian churches of Rome as at San Clemente (422432) (fig. 62). Even the great champion of the pointed Christian style, Pugin, created the Hiberno-Romanesque St. Michael, Gorey (Co. Wexford) (1838-1839), which was essentially followed by McCarthy in his 1860 church of St. Laurence, Ballitore (Co. Kildare) (fig. 63). ${ }^{111}$ The principle was adopted by McCarthy's pupil, Joseph Connolly, at St. John the Evangelist, Gananoque, Ontario (1891) (fig. 64), where we find a rose window in the façade, as at St. Laurence, which provides a model for Holmes at St. Mary of the Assumption. ${ }^{12}$ It is significant that Connolly's and Holmes's Hiberno-Romanesque designs are not just nostalgic recreations of earlier nineteenthcentury churches in Ireland, but are paralleled in the homeland as in Thomas Hevey's Sacred Heart, Dunlewey (Co. Donegal) (1877), and St. Mary, Auchnacloy (Co. Tyrone), by Doolin, Butler and Donnelly (1902-1904).

\section{Welland, St. Mary's Roman Catholic}

Holmes adopted the very same HibernoRomanesque tradition as St. Mary of the Assumption, St. Catharines, and St. Mary's, Welland (1913-1914). ${ }^{113}$ The design of the west front with a central tower is also adapted from Connolly, specifically St. Mary's, Bathurst Street, Toronto (1885), where the central placement of the tower is particularly appropriate at the head of Adelaide Street. ${ }^{114}$ Connolly used the same plan for the façade of St. Mary's Cathedral, Kingston (1889-1891), while Holmes, in partnership with Post, used it for the Holy Name of Mary, St. Mary's, Ontario (1892-1893)..$^{115}$

\section{CONCLUSION}

Our exploration of some of the churches in the Niagara region has revealed considerable stylistic diversity as expressions of particular associations and rivalries between different denominations. From Greek Doric adopted as specifically Scottish in St. Andrew's Presbyterian Church, Niagara-on-the-Lake, through various interpretations of Gothic from English associations for the Anglican Church, to cathedral-like pretension at Welland Avenue Methodist, St. Catharines, and the use of Irish Catholic vocabulary in the churches of Joseph Connolly and Arthur Holmes. Both Connolly and Holmes provided an even clearer Irish expression with the Hiberno-Romanesque churches, while Romanesque in its Lombard guise gave First Presbyterian, St. Catharines, 
something to set them apart from the Anglicans and Methodists in town, just as Richardsonian Romanesque provided the Low Church Anglican St. Thomas, St. Catharines, with a progressive alternative to the High Church Gothic of St. George. The denominational rivalries expressed in these stylistic choices also speak of competition between congregations, especially between the monumental Anglican and Catholic churches in Thorold, and the various congregations in St. Catharines. Such competitive principles are far from being confined to the Niagara region, but apply to communities throughout Canada and deserve to be studied in detail.

\section{NOTES}

1. As ever, I am pleased to record my debt to Robert Hill for his Biographical Dictionary of Architects in Canada 1800-1950, [http:// dictionaryofarchitectsincanada.org/], which has saved countless hours in tracking down references to the buildings discussed here. David Burley accompanied me for most of the fieldwork and provided excellent company, good humour, and valuable insights on the material. I am most grateful to the Social Sciences and Humanities Research Council for funding in support of this project and research on the architecture of Joseph Connolly.

2. For a detailed study of St. Andrew's Presbyterian Church, Niagara-on-the-Lake, see Thurlby, Malcolm, 2018, "St. Andrew's Presbyterian Church, Niagara-on-the-Lake (Ontario), and Church Design in Upper Canada down to 1840," Georgian Group Journal, vol. 26, p. 247262, with colour illustrations.

3. Bridgman, Harry J., "McGill, Robert," Dictionary of Canadian Biography, vol. VIII (1851-1860), n.p., [http://www.biographi. ca/en/bio/mcgill robert $8 \mathrm{E} . \mathrm{html}]$, accessed July 23, 2018.

4. Ibid.

5. St. Andrew's Presbyterian Church, Niagaraon-the-Lake Archives. Leslie Maitland (1984, Neoclassical Architecture in Canada, Ottawa,
Parks Canada p. 114, fig. 102) inaccurately claims that NOTES on the original plan of the church state that the façade is based on the Temple of Theseus. There is no such mention. Arthur, Eric (1938, St. Andrew's Church, Niagara-on-the-Lake, Toronto, School of Architecture, Faculty of Applied Science and Engineering, University of Toronto, p. 7) also refers to the Temple of Theseus.

6. Hill, Robert G., "Cooper, James," Biographical Dictionary of Architects in Canada, n.p., [http://dictionaryofarchitectsincanada.org/ node/962], accessed June 3, 2018.

7. Gibbs, James, 1728, A Book of Architecture, London, [William Bowyer]; Summerson, John, 1977, Architecture in Britain 1530-1830 [ $6^{\text {th }}$ rev., $2^{\text {nd }}$ integrated ed.], Harmondsworth, Penguin Books, p. 357. See also, Coffman, Peter, 2014, "The Gibbsian Tradition in Nova Scotia," in Matthew M. Reeve (ed.), Tributes to Pierre du Prey: Architecture and the Classical Tradition from Pliny to Posterity, New York, Belgium, Harvey Miller, p. 211227, at p. 212.

8. Thurlby, Malcolm, 2017, "Christ's Church, Hamilton, Ontario, and the Changing Image of the Anglican Church - 1835-1875," Journal of the Society for the Study of Architecture in Canada, vol. 42, no. 1, p. 21-42.

9. St. Catharines Journal, April 19, 1855, p. 3. Kivas Tully's tender call, Mail (Niagara-onthe-Lake), May 16, 1855, for reconstruction work at St. Andrew's, including repairing and reconstructing the roof and part of the pews and gallery. On Tully, see Otto, Stephen A., "Tully, Kivas," Dictionary of Canadian Biography, vol. XIII (1901-1910), n.p., [http://www.biographi.ca/en/bio/ tully kivas 13E.html], accessed August 23, 2018.

10. MacRae, Marion and Anthony Adamson, 1975, Hallowed Walls: Church Architecture of Upper Canada, Toronto, Clarke, Irwin, p. 202.

11. Ibid.; Benjamin, Asher, 1820 [2 ${ }^{\text {nd }}$ ed.], Rudiments of Architecture, Boston, R.P. \& C. Williams, p. 93, pls. A and B; also included in Benjamin, Asher, 1827 [6 $6^{\text {th }}$ ed.], The American Builder's Companion, Boston, R.P. \& C. Williams (reprinted New York, Dover Books), p. 108, pls. K and L. See also: Arthur, Eric, 1927, "The Early Architecture of Ontario: St. Andrew's Presbyterian Church," R.A.I.C. Journal, vol. iv, p. 313-317; and Arthur, St. Andrew's Church, Niagara-onthe-Lake, op. cit.
12. Benjamin, Asher, 1797, Country Builder's Assistant, Greenfield, MA, Thomas Dickman, pl. 27.

13. MacRae and Adamson, Hallowed Walls, p. 202-204; Nicholson, Peter, 1823, The New Practical Builder, and Workman's Companion, London, Thomas Kelly, p. 568570, pls. XVI-XXI.

14. Stuart, James and Nicholas Revett, 1895, Antiquities of Athens, vol. III, London, John Haberkorn, chap. I, pl. III.

15. McAleer, J. Philip, 1993 A Pictorial History of St. Paul's Anglican Church, Halifax, Nova Scotia, Halifax, NS, Resource Centre Publications, Faculty of Architecture, Technical University of Nova Scotia; Coffman, "The Gibbsian Tradition in Nova Scotia," p. 211-227.

16. Noppen, Luc and Lucie K. Morisset, 1995, La présence anglicane à Québec: Holy Trinity Cathedral (1796-1996), Québec, Septentrion.

17. Robertson, John Ross, 1894, Landmarks of Toronto, 6 vol., vol. I, Toronto, J. Ross Robertson, p. 278.

18. Id., ill. on p. 279.

19. The intended design is recorded by Thomas Young's 1835 watercolour of King Street looking east. The unfinished appearance of the church is illustrated in Robertson, John Ross, Sketches in City Churches, Toronto, J. Ross Robertson, p. 17. Morriss, Shirley, with Carl Benn, 1998, "Architecture," in William Cooke (ed.), The Parish and Cathedral Church of St. James, Toronto, 1797-1997: A Collaborative History, Toronto, University of Toronto Press, p. 184-190; Vattay, Sharon, 2001, Defining "Architect" in Nineteenthcentury Toronto: The Practices of John George Howard and Thomas Young, Ph.D. thesis, University of Toronto, p. 147-152, [http://www.collectionscanada.gc.ca/obj/ s4/f2/dsk3/ftp04/NQ58974.pdf], accessed August 23, 2018.

On Thomas Rogers, see Stewart, J. Douglas, "Rogers, Thomas," Dictionary of Canadian Biography, vol. VIII (1851-1860), n.p., [http://www.biographi.ca/en/bio/rogers thomas 8E.html], accessed August 23, 2018.

20. Illustrated in Robertson, Landmarks of Toronto, p. 507; Vattay, Defining "Architect" in Nineteenth-century Toronto, p. 152-154.

21. Arthur, Eric, 1986 [3 $3^{\text {rd }}$ ed.], Toronto: No Mean City, revised by Stephen Otto, Toronto, University of Toronto Press, p. 76, ill. 4.9. 
22. Robertson, Sketches in City Churches, $\mathrm{p}$. 84-85, ill. on p. 86; Dendy, William, 1978, Lost Toronto, Toronto, Oxford University Press, p. 122-123. pl. 80.

23. McKendry, Jennifer, 1995, With Our Past Before Us: Nineteenth-century Architecture in the Kingston Area, Toronto, Buffalo, and London, University of Toronto Press, p. 59-65; McKendry, Jennifer, 1988, "The Architects of St. George's Cathedral, Kingston," Queen's Quarterly, vol. 95, no. 3, p. 699-713; Stewart, J. Douglas, 1991, "George Browne's Influence. The Architectural Heritage of St. George's," in Donald Swainson (ed.), St. George's Cathedral: Two Hundred Years of Community, Kingston, Ontario, Quarry Press, p. 29-63.

24. McKendry, With Our Past Before Us, p. 59-65.

25. Maitland, Neoclassical Architecture in Canada, p. 121, fig. 109. The church was destroyed by fire in 1888 .

26. Epstein, Clarence, 2012, Montreal, City of Spires: Church Architecture during the British Colonial Period, 1760-1860, Québec, Presses de I'Université du Québec, p. 73-79, figs. 34-38.

27. Id., p. 132-134, figs. 71-72.

28. Maitland, Neoclassical Architecture in Canada, p. 115, fig. 103.

29. Id., p. 153-154, fig. 85 .

30. Epstein, Montreal, City of Spires, p. 155-156, figs. 8788.

31. Watkin, David, 1982, "Athenian" Stuart: Pioneer of the Greek Revival, London, George Allen \& Unwin, p. 21.

32. Nicholson, Peter, 1809, Principles of Architecture, 3 vols., vol. III [2 $2^{\text {nd }}$ ed.], London, J. Barfield and T. Gardiner, p. 1926.

33. Id., p. 26-28, pls. 128-129.

34. Nicholson, Peter, 1823 [ $5^{\text {th }}$ ed.], The Students' Instructor in Drawing and Working the Five Orders of Architecture, London, J. Taylor at the Architectural Library, esp. p. 613.

35. Nicholson, The New Practical Builder, and Workman's Companion, op. cit.

36. Benjamin, The American Builder's Companion, p. 105, pl. LVI.

37. Id., p. 59-63.

38. Benjamin, Asher, 1830. The Architect, or Practical House Carpenter, Boston, L. Coffin, p. 1718, pl. IV.
39. Gwilt, Joseph, 1826, Rudiments of Architecture, London, Priestley and Weale, p. 118, pl. III.

40. Haviland, John, Builder's Assistant, Containing the Five Orders of Architecture, for the Use of Builders, Carpenters, Masons, Plasterers, Cabinet Makers, and Carvers..., 3 vols., Philadelphia, John Bioren, 1818, 1819, 1821, vol. III, pls. 127-128.

41. Id., vol. II, pl. 71.

42. The Oxford Dictionary of the Christian Church [2 ${ }^{\text {nd }}$ ed.], F[rank] L[eslie] Cross and Elizabeth A. Livingstone (eds.), Oxford, Oxford University Press, 1974, p. 1120.

43. Lowrey, John, 2001, "Caesarea to Athens: Greek Revival Edinburgh and the Question of Scottish Identity in the Union State," Journal of the Society of Architectural Historians, vol. 60 , no. 2 , p. 136-157.

44. Williams, Hugh William, 1820, Travels in Italy, Greece and the Ionian Islands, 2 vols., Edinburgh, Archibald Constable and Co.

45. Williams, Hugh William, 1829, Select Views in Greece with Classical Illustrations, originally published in 12 parts between 1823 and 1829 , then as a collected edition, London, Longman, Rees, Orme, Brown and Green, n.p.

46. Anonymous, "On the Proposed National Monument at Edinburgh," Blackwood's Edinburgh Magazine, vol. V, no. XXVIII (July 1819), p. 377-387.

47. Id., p. 377.

48. Id., p. 383.

49. Ibid.

50. Id., p. 384-385.

51. Britton, John, 1829, Modern Athens: Displayed in a Series of Views of Edinburgh in the Nineteenth Century, London, Jones \& Co.

52. Id., pl. 9.

53. Hill, Robert G. "Tully, Kivas," Biographical Dictionary of Architects in Canada, n.p., [http://dictionaryofarchitectsincanada.org/ node/1367], accessed August 23, 2018.

54. Benjamin, Rudiments of Architecture, p. 93; Benjamin, The American Builder's Companion, p. 108.

55. Langley, Batty, 1747, Gothic Architecture Improved by Rules and Proportions, London, John Millan, pl. XL.
56. Thurlby, Malcolm, 1986, "Nineteenthcentury Churches in Ontario: A Study in the Meaning of Style," Historic Kingston, vol. 35, 96-118, at p. 98, fig. 2.

57. I am most grateful to David Cowan for facilitating my access to Beaverdams Chapel.

58. [https://friendsofbeaverdamschurch.com/], accessed July 27, 2018.

59. St. Catharines Public Library, First Presbyterian Church, 1834-1877, File no. 02/ pt2/2-1.1.

60. For illustration, see [http://bmd.stcatharines. library.on.ca/en/3198706/image/2745655] accessed July 27, 2018.

61. Hill, Robert G, "Howard, John George," Biographical Dictionary of Architects in Canada, n.p.,[http://dictionaryofarchitectsincanada.org/node/1532], accessed June 23, 2018. For Howard's church of Holy Trinity Chippawa, in the Niagara region, see Duggan, Alana, 2018, "The Churches of John G. Howard: The State of Research and Open Questions," Journal of the Society for the Study of Architecture in Canada, vol. 43, no. 1, p. 17-31, at p. 28, and p. 20-21, figs. 79 .

62. Wilson, William Carus, $1835, \mathrm{Helps}$ to the Building of Churches, pl. 2, Kirkby Lonsdale, Arthur Foster.

63. Webster, Christopher (ed.), 2003, "Temples.. Worthy of His Presence": the Early Publications of the Cambridge Camden Society, Reading, Spire Books.

64. The impact of the Cambridge Camden (later Ecclesiological) Society on Anglican Church architecture in Canada has been much discussed; see in particular: Christianson, Paul, 2017, "Anglican Churches in Canada West in the 1840s," Journal of the Society for the Study of Architecture in Canada, vol. 42 no. 1, p. 79108; and, from Thurlby, Malcolm: 2007, "Two Churches by Frank Wills: St. Peter's, Barton, and St. Paul's, Glanford, and the Ecclesiological Gothic Revival in Ontario," Journal of the Society for the Study of Architecture in Canada, vol. 32, no. 1, p. 49-60; 2013, "Christ Church, Maugerville, New Brunswick: Bishop John Medley, Frank Wills and the Transmission of Ecclesiological Principles in Anglican Churches in Canada," Journal of the Society for the Study of Architecture in Canada, vol. 38, no. 1, p. 21-28; and 2015, "Bishop John Medley (1804-1892), Frank Wills (1822-1857), and the designs of Christ Church Cathedral and St. Anne's Chapel of Ease, Fredericton, New Brunswick, with some elementary remarks 
on the impact of Bishop John Medley and Frank Wills on the arrangements of Anglican churches in New Brunswick," Journal of the Society for the Study of Architecture in Canada, vol. 40, no. 1, p. 31-57. See also, from Coffman, Peter: 2008, Newfoundland Gothic, Québec, MultiMondes, p. 51-151; and 2016, "Meanings of Gothic in Atlantic Canada, c. 1840-1890," in Timothy Brittain-Catlin, Jan De Maeyer and Martin Bressani (eds.), Gothic Revival Worldwide: A.W.N. Pugin's Global Influence, Leuven, Leuven University Press, p. 64-75, esp. p. 65-69.

65. Pugin, A. Welby, 1841, True Principles of Pointed or Christian Architecture, London, John Weale; Jobson, Frederick J. 1850, Chapel and School Architecture as Appropriate to the Buildings of Nonconformists Particularly to Those of the Wesleyan Methodists: With Practical Directions for the Erection of Chapels and School-Houses, London, Hamilton, Adams \& Co.

66. Pocock, William Fuller, 1824, Designs for Churches and Chapels of Various Dimensions and Styles, \&c., London, J. Taylor. My thanks to Barry Magrill for this reference, pl. 3.

67. Otto, "Tully, Kivas," Dictionary of Canadian Biography, op. cit.; and Hill, "Tully, Kivas," Biographical Dictionary of Architects in Canada, op. cit.

68. Open seats versus pews was a hot topic amongst ecclesiologists at the time; in 1842 the Cambridge Camden Society published a four-page pamphlet entitled Twentythree Reasons for Getting Rid of Church Pews, which sold for one penny or five shillings per hundred. The Ecclesiologist, vol. 1, nos. XII-XIII, 1842, p. 209. See also: "Pues," The Ecclesiologist, vol. 2, 1843, p. 61; The Writer of the History of Pues, "Pues or Pens," The Ecclesiologist, vol. 2, 1843, p. 101-104; "Open Seats," The Ecclesiologist, vol. 2, 1843, p. 122-125; "Open Seats," The Ecclesiologist, vol. 2, 1843, p. 162-163; and Medley, John, 1843, "The Advantages of Open Seats," Transactions of the Exeter Diocesan Architectural Society, vol. 1, p. 155170; which was also published as a book the same year: The Advantages of Open Seats, Oxford, I. Shrimpton.

69. Brandon, Raphael and J. Arthur Brandon, 1849, The Open Timber Roofs of the Middle Ages, London. David Bogue, pls. XIX-XX.

70. I am indebted to Reverend Dorothy Hewlett, Rector of Christ Church, McNab, for facilitating my study of the church.
71. The Church, August 4, 1853, p. 2.

72. On William Thomas, see Neil Einersson, "Thomas, William," n.p., [http://www.biographi.ca/en/bio/thomas william 8E.html], accessed July 23, 2018; and Robert G. Hill, Biographical Dictionary of Architects in Canada, n.p., [http://www.dictionaryofarchitectsincanada.org/node/1355], accessed July 23, 2018.

73. Thurlby, "Two Churches by Frank Wills," p. 49-60.

74. Street, Geo(rge) E, 1850, "On the Proper Characteristics of a Town Church," The Ecclesiologist, vol. XI, p. 227-233, at p. 229.

75. Thurlby, Malcolm, 2006, “Nineteenthcentury Churches in Prince Edward Island and their Place in the Gothic Revival," Journal of the Society for the Study of Architecture in Canada, vol. 31, no. 2, p. 65-85, figs. 1618.

76. A Glossary of Terms used in Grecian, Roman, Italian and Gothic Architecture [4 ${ }^{\text {th }}$ ed.], 1845, Oxford, John Henry Parker; Brandon and Brandon, The Open Timber Roofs of the Middle Ages, op. cit.

77. Thurlby, "Christ's Church, Hamilton, Ontario," p. 2142.

78. See note 68 .

79. Thurlby, "Christ's Church, Hamilton, Ontario," op. cit.

80. On William Hay, see Armstrong, Frederick H., "Hay, William," Dictionary of Canadian Biography, n.p., [http://www.biographi. ca/en/bio/hay william 11E.html], accessed August 3, 2018; Iron, Candace, 2016, Henry Langley: A Man Who Built Churches: Religion and Architecture in $19^{\text {th }}$-century Ontario, Ph.D. dissertation, York University, Toronto, p. 2657, [https://www.library.yorku. ca/find/Record/10315-32652], accessed June 23, 2018, also by Iron: 2016, "Adapting Pugin's True Principles to Canada: William Hay's Architectural Theory," in Timothy Brittain-Catlin, Jan De Maeyer and Martin Bressani (eds.), Gothic Revival Worldwide: A.W.N. Pugin's Global Influence, Leuven, Leuven University Press, p. 54-63; Magrill, Barry, 2004, "'Development' and Ecclesiology in the Outposts of the British Empire: William Hay's Gothic Solutions for Church Building in Tropical Climates (1840-1890)," Journal of the Society for the Study of Architecture in Canada, vol. 29, nos. 12, p. 16-26.

81. Hay, William, 1853, "The Late Mr. Pugin and the Revival of Christian Architecture," Anglo-American Magazine, vol. II, p. 70-73, reprinted in Simmins, Geoffrey (ed.), 1992, Documents in Canadian Architecture, Peterborough, Ontario, Broadview Press; see also: Hay, William, 1854, "Ecclesiastical Architecture: Village Churches," AngloAmerican Magazine, vol. 4, p. 20-22.

82. Ibid.; Iron, Henry Langley: A Man Who Built Churches, p. 38-39; Iron, "Adapting Pugin's True Principles to Canada," p. 63, figs. 4, 10.

83. "Church Improvements" published in both the Montreal Gazette, January 13, 1860, p. 2, and the Ottawa Citizen, January 31, 1860, p. 1. Mildenhall, Dorothy, 2015, Thomas Fuller: Architect for a Nation, Victoria, BC, Larkhill Books, p. 64.

84. Barr, Edward, 1849, Elevations, Sections and Details of Strixton Church, Northamptonshire, Oxford, John Henry Parker.

85. Pugin, 1841, True Principles of Pointed or Christian Architecture, p. 19-20.

86. Brandon, Raphael and J. Arthur Brandon, 1846, Parish Churches, London, George Bell, p. 33-34 + illustrations. Iron (in Henry Langley: A Man Who Built Churches, p. 40) also draws attention to: Barr, James, 1842, Anglican Church Architecture with some Remarks upon Ecclesiastical Furniture, and "Church Roofing," The Ecclesiologist, nos. XXXI-XXXII, May 1844, p. 101-107, ill. on p. 104.

87. Iron, Candace, 2006, "Why Such an Odd Plan? Milton Earl Beebe's St. Thomas Anglican Church, St. Catharines, Ontario," Journal of the Society for the Study of Architecture in Canada, vol. 31, p. 11-22.

88. Ibid.

89. Hill, Robert G, "Badgley, Sidney Rose," Biographical Dictionary of Architects in Canada, n.p., [http://dictionaryofarchitectsincanada.org/node/1020], accessed July 26, 2018.

90. [http://bmd.stcatharines.library.on.ca/ en/3236540/image/2981207], accessed July 26, 2018.

91. Wakeling, Christopher, 1995, "The Nonconformist Tradition: Chapels, Change and Continuity," in Chris Brooks and Andrew Saint (eds.), The Victorian Church: Architecture and Society, Manchester, University of Manchester Press, p. 82-97, at p. 92; also from Wakeling, see 2017, Chapels of England: Buildings of Protestant Nonconformity, Swindon, Historic England. See also Thurlby, Malcolm, 2005, 
"Nonconformist Churches in Canada 18501875," Ecclesiology Today, vol. 34, p. 53-73, [http://www.ecclsoc.org/ET.34.pdf], accessed July 29, 2018.

92. Id., p. 69-70; Dendy, Lost Toronto, op. cit.

93. Carr, Angela, 1995, Toronto Architect Edmund Burke, Redefining Canadian Architecture, Montreal and Kingston, McGill-Queen's University Press.

94. On Connolly's churches, see Thurlby, Malcolm, 2016, "The Roman Catholic Churches of Joseph Connolly (1840-1904): The Adaptation of Pugin's True Principles and Aspects of Irish Identity in Ontario," in Timothy Brittain-Catlin, Jan De Maeyer and Martin Bressani (eds.), Gothic Revival Worldwide: A.W.N. Pugin's Global Influence, Leuven, Leuven University Press, p. 76-93, with further references; Thomas, Christopher A., 1986, "A High Sense of Calling: Joseph Connolly, A.W. Holmes, and their Buildings for the Roman Catholic Archdiocese of Toronto, 1885-1935," RACAR, vol. XIII, no. 2, p. 97-120. For lists of Connolly's buildings with detailed documentation, see Hill, Robert G., A Biographical Dictionary of Architects in Canada, n.p., [http://dictionaryofarchitectsincanada.org/architects/ view/148] and [http://dictionaryofarchitectsincanada.org/architects/view/1622], accessed August 23, 2018. To these should be added St. Peter, Ayton (1878); St. Paul, Dornoch (1890); the Chapel of the House of Providence, Kingston (1898); and Holy Name of Mary, Sault Sainte Marie, Michigan (1881).

95. Thurlby, Malcolm, 1990, "The Church of Our Lady of the Immaculate Conception at Guelph: Puginian Principles in the Gothic Revival Architecture of Joseph Connolly," Society for the Study of Architecture in Canada Bulletin, vol. 15, p. 32-40; Thurlby, Malcolm, 2015, "Joseph Connolly's Masterpiece: The Basilica of Our Lady Immaculate, Guelph," n.p., [http://raisethehammer.org/article/2706], accessed September 1, 2018.

96. Thurlby, Malcolm, 2004, "Two Late Nineteenth-century Roman Catholic Churches in Toronto by Joseph Connolly: St. Mary's, Bathurst Street, and St. Paul's, Power Street," Ecclesiology Today, vol. 33, p. 27-48, [file:///C:/Users/malcolm/ Downloads/ET.33\%20(1).pdf], accessed November 25, 2018.
97. Thurlby, Malcolm, 2005, "Joseph Connolly in the Roman Catholic Archdiocese of Kingston, Ontario," Journal of the Society for the Study of Architecture in Canada, vol. 30, p. 25-38.

98. Thurlby, Malcolm, 1992, "Joseph Connolly's Roman Catholic Churches in Wellington County," Historic Guelph, vol. XXXI, p. 431.

99. Crook, J. Mordaunt, 1985, "Early French Gothic," in Sarah Macready and Frederick Hugh Thompson (eds.), Influences in Victorian Art and Architecture, London, Society of Antiquaries, p. 49-58.

100. [http://dictionaryofarchitectsincanada. org/node/148]; [http://dictionaryofarchitectsincanada.org/node/1622], accessed September 8, 2018.

101. Thurlby, Malcolm, 2004, "The 'Roman Renaissance' Churches of Joseph Connolly and Arthur Holmes and their place in Roman Catholic Church Architecture," Journal of the Society for the Study of Architecture in Canada, vol. 29, nos. 34, p. 27-40.

102. Hill, Robert G., "Allan, William Bryson," Biographical Dictionary of Architects in Canada, n.p., [http://dictionaryofarchitectsincanada.org/node/25], accessed September 8, 2018.

103. Hill, Robert G., "Holmes, Arthur William," Biographical Dictionary of Architects in Canada, [http://dictionaryofarchitectsincanada.org/architects/view/264], accessed September 10, 2018; Hill, Robert G., "Post, Albert Asa," Biographical Dictionary of Architects in Canada, n.p., [http://dictionaryofarchitectsincanada.org/architects/ view/1395], accessed September 10, 2018; Thomas, Christopher A., 1985, "A Thoroughly Traditional Architect: A.W. Holmes and the Catholic Archdiocese of Toronto 1890-1940," in Society for the Study of Architecture in Canada Bulletin, vol. X, p. 39; Thomas, Christopher A., 1986, "A High Sense of Calling: Joseph Connolly, A.W. Holmes, and their Buildings for the Roman Catholic Archdiocese of Toronto, 1885-1935," RACAR, vol. XIII, no. 2, p. 97-120.

104. Hill, "Post, Albert Asa," Biographical Dictionary of Architects in Canada, op. cit.; and Catholic Register, June 13, 1895, p. 4, August 6, 1896, p. 5.

105. Thurlby, Malcolm, 2006, "Two Churches by Joseph Connolly in Hamilton," n.p., [http://www.raisethehammer.org/index. asp?id=306], accessed September 10, 2018.
106. Thurlby, Malcolm, 1993, "Joseph Connolly and St. Joseph's Roman Catholic Church, Macton," Historic Guelph, vol. XXXII, p. 71-72.

107. Thurlby, 2005, "Joseph Connolly in the Roman Catholic Archdiocese of Kingston, Ontario," p. 32, figs. 31-32.

108. Thurlby, Malcolm, 2003, "St. Patrick's Roman Catholic Church, School and Convent in St. John's, Newfoundland: J.J. McCarthy and Irish Gothic Revival in Newfoundland," Journal of the Society for the Study of Architecture in Canada, vol. 28, no. 3, p. 13-20.

109. Hill, Robert G, "Holmes, Arthur William," Biographical Dictionary of Architects in Canada, op. cit.; and Catholic Register, June 16, 1898, p. 1.

110. Contract Record, vol. xxvi, April 3, 1912, p. 72; Catholic Register, February 12, 1914, p. 1.

111.Sheehy, Jeanne, 1977, J.J. McCarthy and the Gothic Revival in Ireland, Belfast, Ulster Architectural Heritage Society, p. 52.

112. Thurlby, 2005, "Joseph Connolly in the Roman Catholic Archdiocese of Kingston, Ontario," figs. 19 and 41.

113. Contract Record, vol. xxvii, November 12, 1913 p. 68.

114. Thurlby, "Two Late Nineteenth-century Roman Catholic Churches," p. 30-48.

115. Hill, "Post, Albert Asa," Biographical Dictionary of Architects in Canada, op. cit. 